Universidad de Lima

Facultad de Comunicación

Carrera de Comunicación

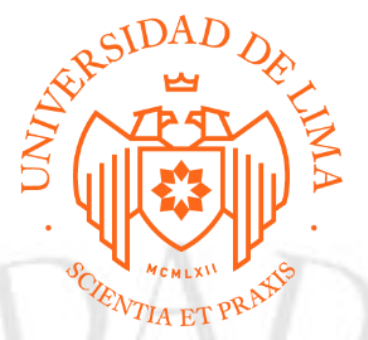

\title{
CAMPAÑA DE COMUNICACIÓN PARA EL CONDOMINIO VILLA PANAMERICANA
}

Trabajo de Suficiencia Profesional para optar el Título Profesional de Licenciado en

Comunicación

Fiorella Estefany Arroyo Vidal

Código 20121493

Diana Gabriela Yong Higa

Código 20121407

Lima - Perú

Octubre de 2019 


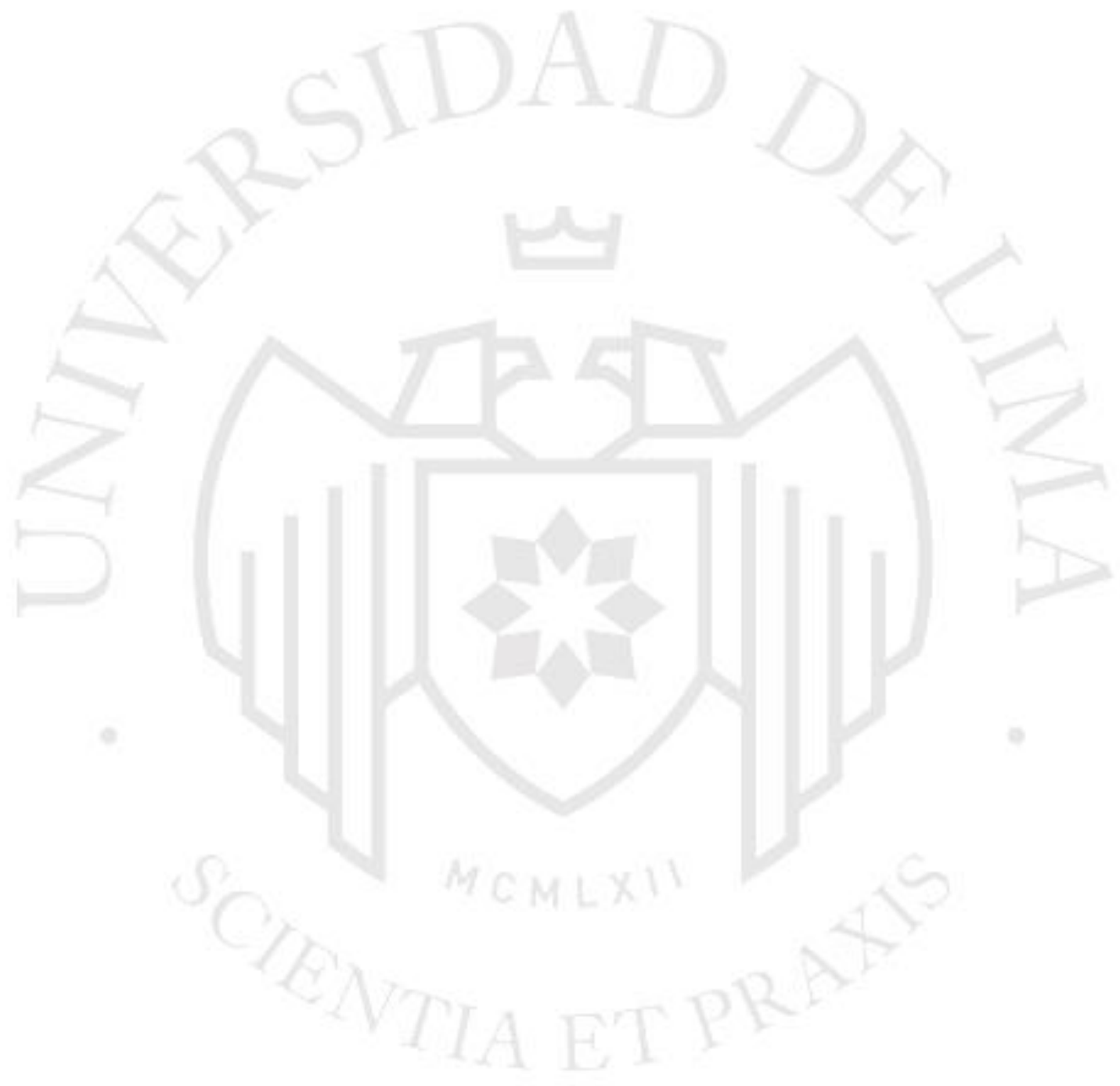


CAMPAÑA DE COMUNICACIÓN PARA EL CONDOMINIO VILLA PANAMERICANA 


\section{ÍNDICE}

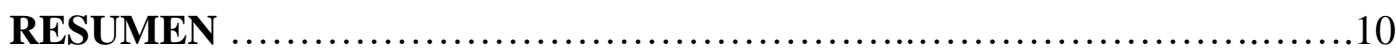

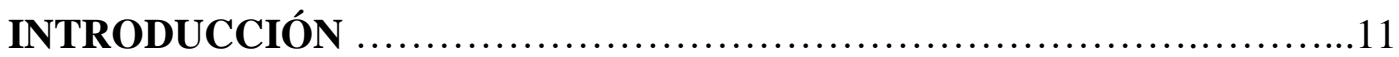

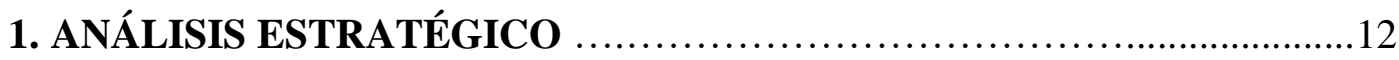

1.1 Definición del producto .....................................12

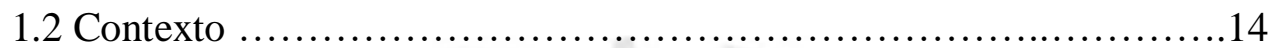

1.2.1 Económico, político y legal .................................14

1.2.2 Sociocultural ...............................................16

1.2.3 Sector inmobiliario .....................................18

1.2.4 Análisis de la competencia ..............................19

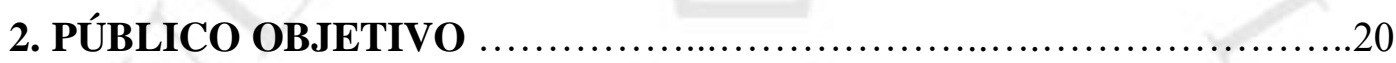

2.1 Público objetivo ................................................26

2.2 Tamaño del mercado ............................................27

2.3 Embudo de ventas .............................................. 31

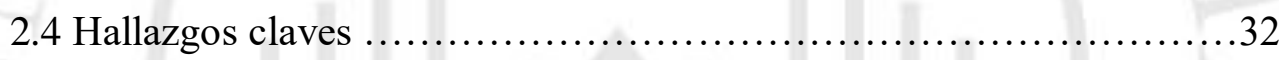

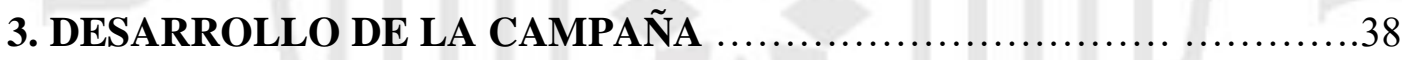

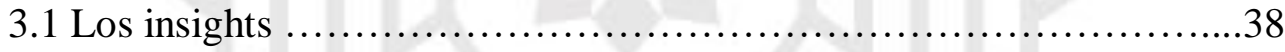

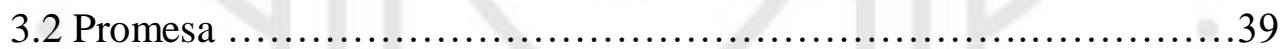

3.3 Posicionamiento deseado .........................................41

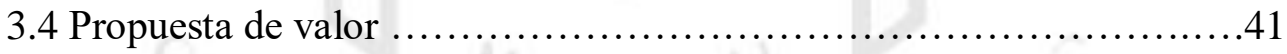

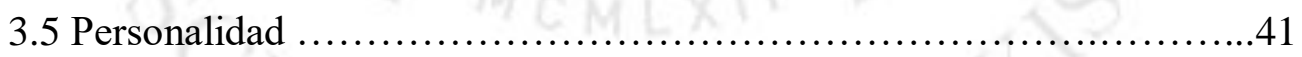

3.6 Tono de la comunicación .......................................41

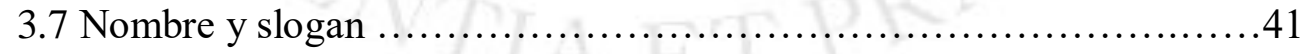

3.8 Identidad visual de la marca ......................................42

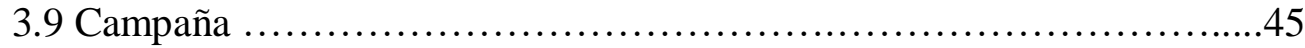

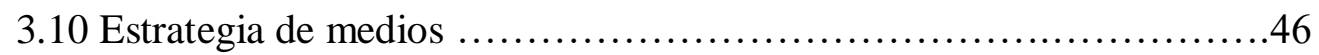

3.10.1 ATL................................................... 47

3.10.2 PR ..................................................56

3.10 .3 BTL ................................................57

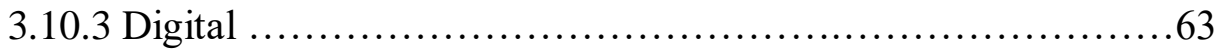


4. RESUMEN DE INVERSIÓN DE PRESUPUESTO .81

5. CONCLUSIONES Y RECOMENDACIONES 82

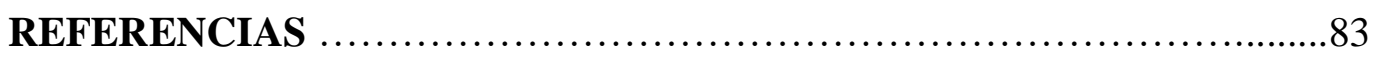

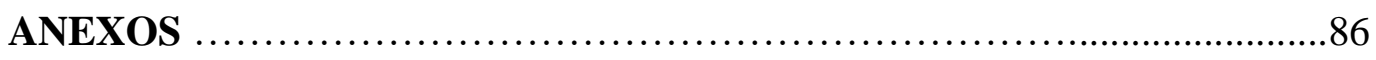


Dirección web de las piezas y producciones de comunicación parte del trabajo

https://drive.google.com/drive/folders/1Ih2X1x98wV-

5tVlliinNWU29wZOJgYuA?usp=sharing 


\section{LISTA DE TABLAS}

Tabla 1: Perfil del limeño por zonas de Lima 2019 - Ipsos

Tabla 2: Características de las viviendas en Lima - Tipo de vivienda - Ipsos

Tabla 3: Estructura socioeconómica 2018 - CPI

Tabla 4: Ingreso medio por NSE - Elaboración propia

Tabla 5: Tamaño de mercado - Elaboración propia

Tabla 6 - Códigos de colores - Elaboración propia

Tabla 7: Etapas de campaña - Elaboración propia

Tabla 8: Guión técnico de spot publicitario - Elaboración propia

Tabla 9: Presupuesto por palabra clave - Google Keyword Planner

Tabla 10: Previsión de métricas - Google Keyword Planner

Tabla 11: Distribución de presupuesto publicitario - Elaboración propia 


\section{LISTA DE FIGURAS}

Figura 1: Comportamiento de la Economía Peruana en el Segundo Trimestre de 2019. INEI

Figura 2: Los parques de Villa el Salvador - Inmobiliaria Viva

Figura 3: Paseo La Campiña - Facebook Inmobiliaria Arteco

Figura 4: Gorriones 3 - Facebook Grupo Toscana

Figura 5: Las Palmas Chorrillos Condominio Ecoamigable - Besco

Figura 6: Las Palmas Chorrillos Condominio Ecoamigable 2 - Besco

Figura 7: Interés de compra de un departamento - BBVA

Figura 8: Embudo de ventas - Elaboración propia

Figura 9: Conocimiento del Nuevo Crédito MiVivienda - Elaboración propia

Figura 10: Conocimiento del Bono Verde - Elaboración propia

Figura 11: Atleta embajador de marca - Elaboración propia

Figura 12: Nombre de condominio - Elaboración propia

Figura 13: Isotipo - Elaboración propia

Figura 14: Prisma de kapferer - Elaboración propia

Figura 15: Búsquedas de Villa Panamericana vs. Villa de Atletas - Google Trends

Figura 16: Panel en Av. Mariano Pastor - Villa El Salvador. Fuente: JMT

Figura 17: NSE de usuarios del Metropolitano - Efectimedios Perú

Figura 18: Ruta alimentador Sur - Efectimedia

Figura 19: Demo de dindeles alimentador Sur - Efectimedia

Figura 20: Lima Digital 20181 - CPI

Figura 21: Lima Digital 2018 2- CPI

Figura 22: Lima Digital 2018 3- CPI

Figura 23: Segmentación por zona - Facebook

Figura 24: Mapa de temperatura Facebook Global Engagement - Rockcontent

Figura 25: Avarege Organic Reach - Social Bakers

Figura 26: Distribución de presupuesto publicitario - Elaboración propiaLANA 


\section{LISTA DE ILUSTRACIONES}

Ilustración 1 - Isotipo Opción 1 - Elaboración propia

Ilustración 1 - Isotipo Opción 2 - Elaboración propia

Ilustración 3: Isotipo explicación - Elaboración propia

Ilustración 4: Isotipo explicación 2 - Elaboración propia

Ilustración 5: Isotipo explicación 3 - Elaboración propia

Ilustración 6: Logotipo + descriptor - Elaboración propia

Ilustración 7: Storyboard - Elaboración propia

Ilustración 8: Diseño de valla publicitaria 1 - Elaboración propia

Ilustración 9: Diseño de valla publicitaria 2 - Elaboración propia

Ilustración 10: Demo de stand en feria - Elaboración propia

Ilustración 11: Ejemplo 1 publicación en Facebook - Elaboración propia

Ilustración 12: Ejemplo 2 publicación en Facebook - Elaboración propia 


\section{RESUMEN EN ESPAÑOL}

En este trabajo se desarrollará una campaña de comunicación para la venta de los departamentos de la Villa Panamericana ubicados en Villa el

Salvador. Se trata de un condominio con infraestructura moderna, ecoamigable, segura y con áreas comunes a un precio accesible para las familias del NSE C y D de Lima Sur que se preocupan por su estabilidad en el futuro. Para este análisis se abarcaron estrategias ATL, BTL, digitales y de relaciones públicas.

Palabras clave: departamentos, ecoamigable, publicidad, inmueble, panamericanos

\section{RESUMEN EN INGLÉS}

This paper develops a communication campaign for the sale of the departments of the Villa Panamericana located in Villa el Salvador, a condominium with modern infrastructure, eco-friendly, safe, with common areas at affordable price for the families of the socioeconomic level $C$ and

$D$ of South Lima who care about their stability in the future. ATL, BTL, digital and public relations strategies were covered.

Keywords: Apartments, Ecofriendly, Advertising, Property, Panamericanos 


\section{INTRODUCCIÓN}

El condominio "Villa Panamericana", ubicado en el distrito de Villa el Salvador, fue construido para acoger a las diversas delegaciones participantes de los últimos Juegos Panamericanos, organizados en

Lima en el año 2019. Los departamentos que conforman este condominio serán puestos en venta al público a partir de enero de 2020. Los departamentos se caracterizan por contar con un diseño moderno, infraestructura ecoamigable, personal de seguridad, áreas verdes, zonas de juegos para niños y serán financiados a través del Nuevo Crédito MiVivienda y Bono Verde. El área de comunicación del Ministerio de Vivienda, Construcción y Saneamiento será el encargado de la campaña de comunicación. Para el desarrollo de la campaña se busca resaltar los insights hallados combinándolos con los beneficios de los departamentos y las modalidades de financiamiento.

La propuesta de la campaña se comunicará en ATL, OOH, BTL, Digital y PR en dos etapas: (i) Lanzamiento y (ii) Mantenimiento, cuyas estrategias nos permitirán llegar a nuestro público objetivo y lograr la venta de la totalidad de los departamentos en un periodo máximo de 6 meses. 


\section{ANÁLISIS ESTRATÉGICO}

\section{CAPÍTULO 1}

\subsection{Definición del producto}

El Condominio Villa Panamericana está ubicado en el distrito de Villa el Salvador, 5to Sector, área zonal 26 en el Complejo Biotecnológico Mz A. El condominio está compuesto por 4 torres de 20 pisos, y 3 torres de 19 pisos. En cada nivel se encuentran 8 departamentos cuyas áreas están comprendidas entre 70 y 75 metros cuadrados. Las viviendas constan de 3 dormitorios, sala, comedor, cocina y dos baños. En total, la Villa tiene 1,096 departamentos, de los cuales 336 han sido diseñados exclusivamente para el fácil acceso de personas con discapacidad, siendo que algunas de las zonas cuentan incluso con el sistema de lectura braile. El condominio cuenta con áreas comunes tales como sala de usos múltiples, juegos para niños, zona de parrillas y amplias áreas verdes. La entidad encargada de la promoción y venta de los departamentos será el Ministerio de Vivienda, Construcción y Saneamiento.

El consorcio Beso-Besalco fue quien ganó la licitación de la obra y estuvo a cargo de la ejecución de la Villa Panamericana. En una entrevista para el diario El Comercio, Carlos Neuhaus, presidente del Comité Organizador de los Juegos Panamericanos de 2019 mencionó que "Besco está hace 20 años en el Perú y ha construido más de 8,500 departamentos, entre ellos el Complejo de Collique (Comas), que se asemeja a lo que van a construir." Por lo tanto, la construcción de los departamentos contó con el respaldo del Estado y una de las más reconocidas y prestigiosas inmobiliarias del país.

El Estado regaló un departamento a cada deportista que obtuvo una medalla de oro, plata y/o bronce en los Juegos Panamericanos y Parapanamericanos 2019. En total fueron 54 deportistas los que ganaron y cumplieron su sueño de la casa propia. Por lo tanto, queda un total de 1042 departamentos para ser vendidos a partir de enero de 2020.

El precio de los departamentos, tanto de aquellos de 70 como de 75 metros cuadrados, será de S/. 186,000.00 (Ciento Ochenta y Seis Mil con 00/100 Soles). En el presente análisis, se determinó que correspondía mantener este precio en ambos tipos de 
departamentos a fin de contar con un precio competitivo para la zona. Se venderán solo a través del Nuevo Crédito MiVivienda (NCMV) y MiVivienda Verde, lo cual significa que los departamentos incluyen características en su diseño y construcción de ahorro y cuidado para el medio ambiente como tecnología para el tratamiento de aguas residuales. Las viviendas tienen sistemas de iluminación de bajo consumo y ahorro de agua, que permiten la reducción del consumo hasta en un 30\%. Asimismo, de acuerdo a la certificación de MiVivienda Verde, estos departamentos cuentan con el Grado 2, por lo que cuentan con un bono adicional del $4 \%$ que se calcula al valor del financiamiento, además del Bono del Buen Pagador del NCMV.

Las personas interesadas en comprar podrán acceder al Bono del Buen Pagador del Nuevo Crédito MiVivienda (S/. 13,000), Bono Verde (S/. 5,938.46) y deberán pagar una cuota inicial (10\%) a la entidad financiera. El financiamiento final será de S/. 148,461.54 y las instituciones financieras por las que se podrá acceder a este crédito son: BCP, Interbanck, BBVA, Scotiabank, Pichincha, Banco del Comercio, Banbif, Banco GNB, CMAC Sullana, CMAC Ica, CMAC Tacna, CMAC Maynas, CMAC Huancayo, CMAC Sullana, CMAC Cusco, CRAC Raíz, Edpyme Mi Casita Hipotecaria, Financiera TFC, Financiera Efectiva.

Según la evaluación realizada con el Banco Interbank en una simulación para estimar las cuotas de la hipoteca de dicho departamento correspondería al pago mensual de S/. 1,300, luego del pago de la cuota inicial. Esto está sujeto al historial crediticio de la persona, el número de años que se solicite el préstamo y la entidad financiera.

De acuerdo a la visita que realizamos a la Villa Panamericana, pudimos observar que el condominio está ubicado cerca de las principales vías de acceso (Av. Mariano Pastor Sevilla y Av. El Sol), así como a bodegas, mercados, farmacias, centros de estudios, iglesias, gasolineras, estaciones de buses, grifos, bancos, restaurantes, entre otros.

Específicamente, entre los centros de estudios cercanos están el SENATI Villa El Salvador, la Universidad Autónoma del Perú y UTP, y algunos colegios, entre los que destacan Trilce y Saco Oliveros. Asimismo, los mercados y supermercados cercanos son el Mercado Virgen de Cocharchas, el Mercado Mayorista Plaza Unicachi Sur, mayoristas Makro, minimarket Mass, centros comerciales como el MegaPlaza Villa el Salvador II y Centro Comercial Miramar. Asimismo, los comercios predominantes son los car wash, ferreterías, alquiler de maquinaria pesada, venta de materiales de construcción, andamios, puertas de garaje, estructuras metálicas, consultorio dental, entre otros. 
Además de los comercios, a unas pocas cuadras se encuentra el Polideportivo Villa El Salvador y el Parque Zonal Huayna Capac, el cual cuenta con un pequeño zoológico y campos de fútbol para actividades en familia. En la Av. Mariano Pastor Sevilla se encuentra el Hospital de Solidaridad de Villa el Salvador "SISOL SALUD" y, en la Av. el Sol (donde se encuentra la Villa Panamericana), hay una salida directa a la Panamericana Sur.

\subsection{Contexto}

\subsubsection{Económico, político y legal}

El Perú, a pesar del enfrentamiento entre el Poder Ejecutivo y el Legislativo, así como los conflictos sociales, no ha dejado de crecer económicamente. En agosto de 2019, el Ministerio de Economía y Finanzas (MEF) bajó su estimado de crecimiento al 3\% frente al 4.2\% proyectado en abril. (Semana Económica, 2019)

Sin embargo, la economía se mantiene en crecimiento. "En el segundo trimestre del año 2019 el Producto Bruto Interno (PBI), a precios constantes de 2007, registró un crecimiento de $1,2 \%$, impulsado por la evolución favorable de la demanda interna $(2,1 \%)$, registrando 40 trimestres de crecimiento ininterrumpido.” (Inei, 2019). El MEF estima el crecimiento de 4\% para el año 2020 (El Comercio, 2019), lo cual representaría una oportunidad para la venta de los departamentos en el primer semestre de 2020. La información descrita se consolida en el siguiente gráfico: 


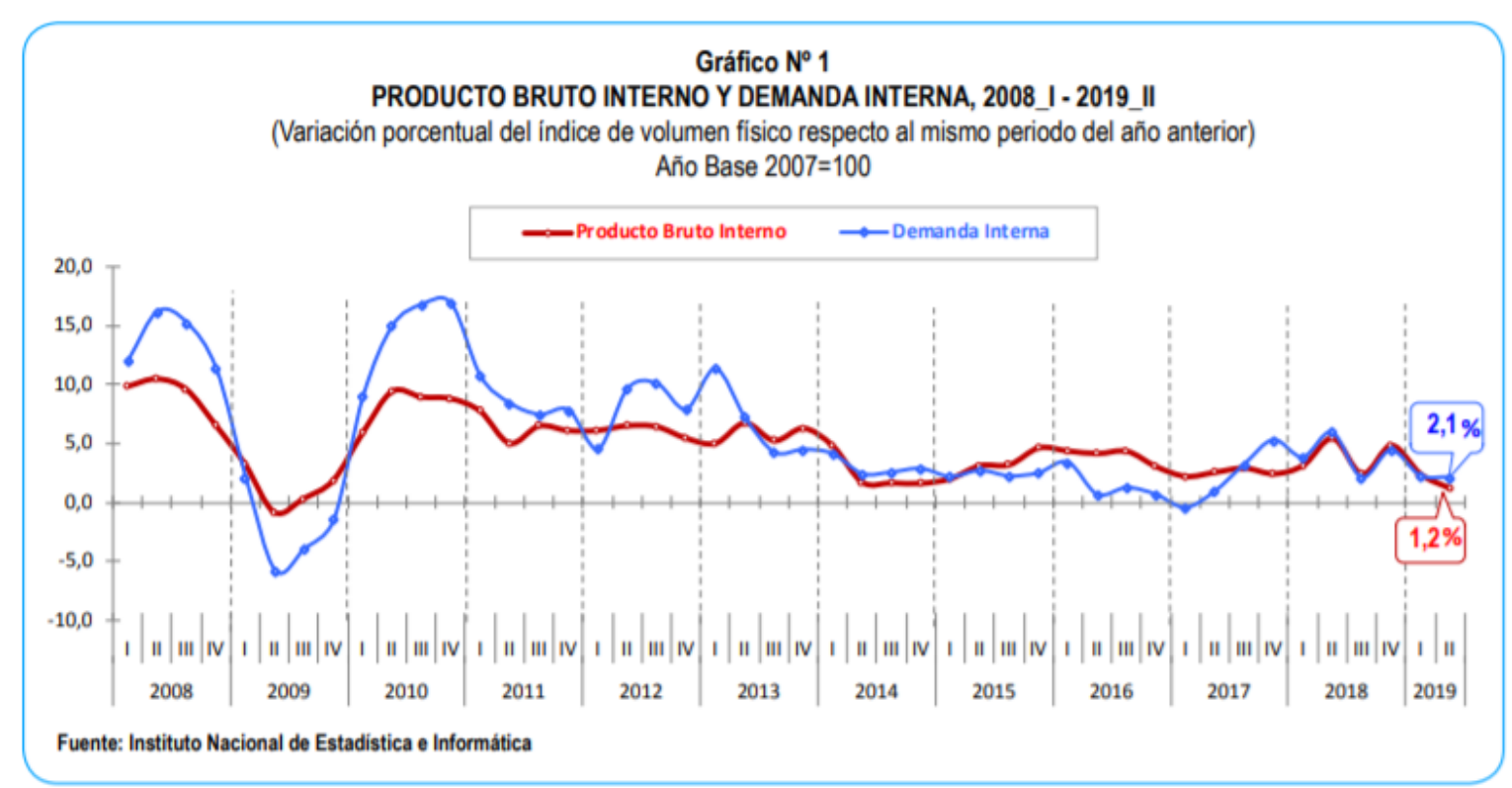

Figura 1: Comportamiento de la Economía Peruana en el Segundo Trimestre de 2019. INEI.

\section{MiVivienda}

"El Nuevo Crédito MiVivienda es un crédito hipotecario financiado por el Fondo MiVivienda, el cual te permite financiar la compra de una vivienda, construir en terreno propio o aires independizados y mejorar tu vivienda" (MiVivienda, s.f.)

En el caso de la compra de un inmueble, "el valor de la vivienda debe oscilar entre S/. 58,800 hasta S/. 419,600 en un plazo de 5 a 20 años de pago. Los requisitos que deben cumplir para acceder a este crédito son: ser mayor de edad, ser calificado por la entidad financiera a través de la cual se hará el préstamo, no tener ningún crédito pendiente de pago con el FMV, no ser propietario o copropietario de otra vivienda a nivel nacional y contar con una cuota inicial mínima de 10\% del valor total de la vivienda" (MiVivienda, s.f.)

"MiVivienda Verde es un programa del Fondo MiVivienda para impulsar y promocionar la compra de viviendas sostenibles. Una vivienda verde es aquella que incorpora criterios de sostenibilidad en su diseño y construcción como contar con sistemas de iluminación, griferías y sanitarios de bajo consumo, con los cuales se puede ahorrar hasta el $30 \%$ mensual en los consumos de agua y luz" (MiVivienda, s.f.) 
“E1 Fondo MiVivienda otorga el Bono Mivivienda Verde como un porcentaje (3\% o 4\%) del valor del financiamiento según el grado de sostenibilidad para la adquisición de una vivienda verde en un proyecto certificado." (MiVivienda, s.f.)

\subsubsection{Sociocultural}

\section{Hogares limeños}

Según el estudio "Perfiles socioeconómicos de Lima" (Ipsos, 2019), el 38\% de hogares en Lima son nucleares, es decir, viven los padres y los hijos. El 38\% es ampliado, es decir, la familia nuclear más otros familiares o no familiares. Los hogares por vivienda son 1.4.

El número de miembros por hogar en promedio dentro del NSE C es 3.9 miembros, del NSE D es de 3.7 miembros. Esto representa que el promedio de familias limeñas del sector C y D pueden habitar cómodamente en un departamento de 3 habitaciones.

Sólo el 55\% de hogares limeños tiene una vivienda totalmente pagada. El 71\% vive en una casa independiente frente al $21 \%$ que vive en departamento.

En promedio, los hogares limeños cuentan con 3.7 ambientes, 2.4 habitaciones y 1.5 baños, composición que es superada por los departamentos de la VILLA PANAMERICANA.

\section{Hogares en Lima Sur}

Según el informe "Estadística poblacional 2019" (Ipsos, 2019), el 41\% de la población en Lima Sur es soltera, el $25 \%$ es casada y el $26 \%$ es conviviente, por lo que vemos que el $51 \%$ de las personas viven en pareja y, en parte, ya formaron una familia. Como dato adicional, $4 \%$ es separado, $3 \%$ es viudo y $1 \%$ es divorciado. La información descrita se consolida en el siguiente gráfico: 


\begin{tabular}{|l|c|c|c|c|c|c|c|}
\hline \multicolumn{1}{|c|}{ Religión } & Lima Met. & Callao & Centro & Este & Moderna & Norte & Sur \\
\hline \hline Soltero/a & $41 \%$ & $40 \%$ & $43 \%$ & $41 \%$ & $41 \%$ & $41 \%$ & $41 \%$ \\
\hline \hline Conviviente & $23 \%$ & $24 \%$ & $20 \%$ & $28 \%$ & $10 \%$ & $26 \%$ & $26 \%$ \\
\hline \hline Casado/a & $26 \%$ & $26 \%$ & $26 \%$ & $23 \%$ & $37 \%$ & $25 \%$ & $25 \%$ \\
\hline \hline Separado/a & $4 \%$ & $5 \%$ & $4 \%$ & $5 \%$ & $3 \%$ & $4 \%$ & $4 \%$ \\
\hline Viudo/a & $4 \%$ & $4 \%$ & $5 \%$ & $3 \%$ & $5 \%$ & $3 \%$ & $3 \%$ \\
\hline \hline Divorciado/a & $2 \%$ & $1 \%$ & $2 \%$ & $1 \%$ & $4 \%$ & $1 \%$ & $1 \%$ \\
\hline
\end{tabular}

Tabla 1: Perfil del limeño por zonas de Lima 2019 - Ipsos

Según el tipo de vivienda, en Lima Sur predominan las casas independientes, siendo estas el $88 \%$ del total de viviendas. Dentro de Lima Metropolitana, la zona con menos departamentos es Lima Sur. En Lima Moderna, por el contrario, predominan los departamentos. En ese sentido, en nuestro análisis hemos identificado la oportunidad de vender el estilo de vida aspiracional de Lima Moderna a Lima Sur. La información descrita se consolida en el siguiente gráfico:

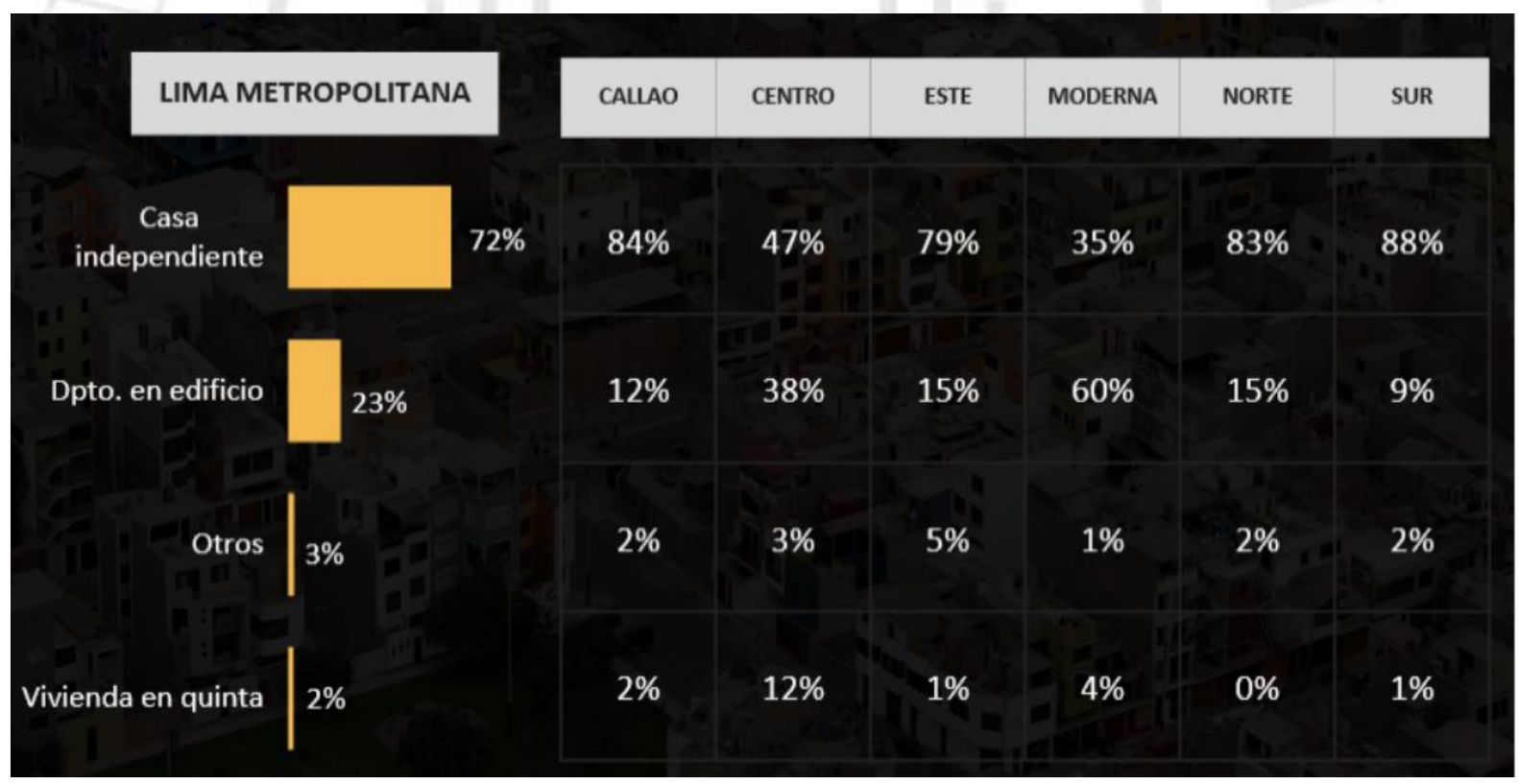

Tabla 2: Características de las viviendas en Lima - Tipo de vivienda - Ipsos

De acuerdo con el informe Perfiles zonales Lima Metropolitana 2019 (Ipsos 2019), el $17.8 \%$ de la población limeña reside en esta zona, siendo el distrito más habitado Villa María del Triunfo, seguido por Villa el Salvador, donde se encuentra la Villa Panamericana. 
La composición del hogar promedio es de 3.9 miembros. Hay 1.3 hogares por vivienda. El $35 \%$ son hogares nucleares y el $29 \%$ está en etapa de desmembramiento.

\section{Perfil del jefe del hogar Lima Sur (Ipsos, 2019)}

- Existen 476 mil jefes del hogar.

- $\quad$ El $66 \%$ es hombre, el $33 \%$ es mujer.

- Predomina el rango de edad entre 40 a 54 años (39\%)

- El $46 \%$ tiene educación secundaria completa, el 34\% tiene educación escolar incompleta.

- $37 \%$ es casado, $30 \%$ es conviviente.

\section{Perfil del adulto joven en Lima Sur (Ipsos, 2019)}

- Existen 486 mil adultos jóvenes.

- La edad promedio es 28 años.

- $35 \%$ es conviviente, $31 \%$ es soltero sin pareja, $27 \%$ es soltero con pareja.

- El 53\% tiene hijos, 1 en promedio.

- El 56\% tiene un trabajo dependiente. El 19\% tiene un trabajo independiente.

- Principales diversiones fuera de casa: Ir al parque, (55\%), hacer deporte (46\%) e ir al cine $(40 \%)$.

\subsubsection{Sector inmobiliario}

Villa el Salvador, así como sus distritos vecinos, San Juan de Miraflores, Villa María del Triunfo o Lurín, carecen de una oferta inmobiliaria y programas de vivienda social, ya que es costumbre en estos lugares la autoconstrucción o la ampliación de la casa familiar. (Empresa Peruana de Servicios Editoriales S. A. EDITORA PERÚ, 2019)

El mercado inmobiliario limeño es dinámico y con mucho potencial. "Se estima que hay 190.000 familias que pueden adquirir viviendas solo en esta ciudad, mientras que hay una oferta constante de 20.000 unidades al mes. Esta demanda debería originar este 
incremento de precios" afirma Diego Abarca, gerente comercial de Paz Centenario. (E1 Comercio, 2019).

Según el Diario Gestión (2019), "El crecimiento de los préstamos MiVivienda gana dinamismo en el año, pese a la desaceleración económica". Entre enero y junio del 2019 se registraron 6,758 créditos entre el Nuevo Crédito MiVivienda y Programa Techo Propio, lo cual representa un aumento del $43.5 \%$ en comparación al mismo periodo del año 2018. El precio promedio de las viviendas sociales disminuyó $4.2 \%$ este año.

El metraje promedio en las viviendas ha disminuido y con ello el precio de los inmuebles. El promedio de área construida por vivienda en Lima es $63.4 \mathrm{~m} 2$. En Villa el Salvador, el promedio de área construida es 60.82 metros cuadrado (Gestión, 2019), tamaño superado por los departamentos en Villa Panamericana, los cuales tienen 70 y 75 metros cuadrados de área.

La construcción de la Villa Panamericana le costó al Estado S/ 405 millones que desembolsó al Consorcio Besco - Besalco. Solo para recuperar lo invertido, se tendrían que vender los departamentos de 75 metros cuadrados a 370 mil soles. Sin embargo, para tener un precio competitivo, se tendría que valorar el de 75 metros cuadrados en S/ 202 mil soles. (Gestión 2019).

En Villa el Salvador, "las familias buscan pisos bajos por temor a los sismos, así como al temor de problemas con ascensores que obliguen a subir escaleras por largos tramos", afirma Marco del Río, presidente de la Asociación de Desarrolladores Inmobiliarios del Perú (Gestión, 2019). También explica que las familias que se muden a la Villa Panamericana deben estar en capacidad de cubrir los costos de mantenimiento que implica vivir en una torre de departamentos, tales como el mantenimiento de ascensores y jardines, limpieza de áreas comunes y servicio de seguridad. 


\subsubsection{Análisis de la competencia}

Se realizó una investigación de las inmobiliarias que cuentan con viviendas en venta que se financien con el Nuevo Crédito Mivivienda y/o Mi Vivienda Verde, y que se encuentren principalmente en los distritos de Lima Sur.

\section{1. "Los Parques de Villa EI Salvador II"}

La inmobiliaria VIVA que pertenece a Graña y Montero cuenta con un proyecto en venta denominado "Los

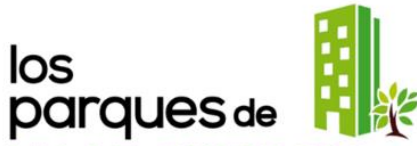

VILLA EL SALVADOR II

condominios Parques de Villa El Salvador II" ubicado en la Av. Algarrobos cruce con Calle Los Cedros, Villa el Salvador. Este condominio recibe financiamiento del Nuevo Crédito Mivivienda sus precios van desde S/. viva 130,000 con áreas desde $58.56 \mathrm{~m} 2$. Tiene 14 edificios, 5 pisos por edificio, un total de 280 departamentos y 93

estacionamientos. Además, cuenta con áreas comunes:

- $1,400 \mathrm{~m} 2$ de áreas verdes interiores

- 2 porterías para control de ingreso peatonal y/o vehicular

- Parque con zonas recreativas

- Club House: Sala de usos múltiples, 01 local comercial y terraza

La propuesta de valor de esta vivienda se basa en ofrecer una alternativa innovadora en el sector inmobiliario enfocada en el bienestar para sus clientes y el acceso igualitario a condiciones de vivienda saludable y seguras. Además, cuentan con un programa de beneficios como el Programa Referidos, Programas de Financiamiento, Programa Ayni para incentivar la buena convivencia entre las familias, y Eco Viva, el cual consiste en el tratamiento de aguas grises, un sistema de reutilización del agua de las duchas, cocina y lavandería para utilizarla en el riego de las áreas verdes. 


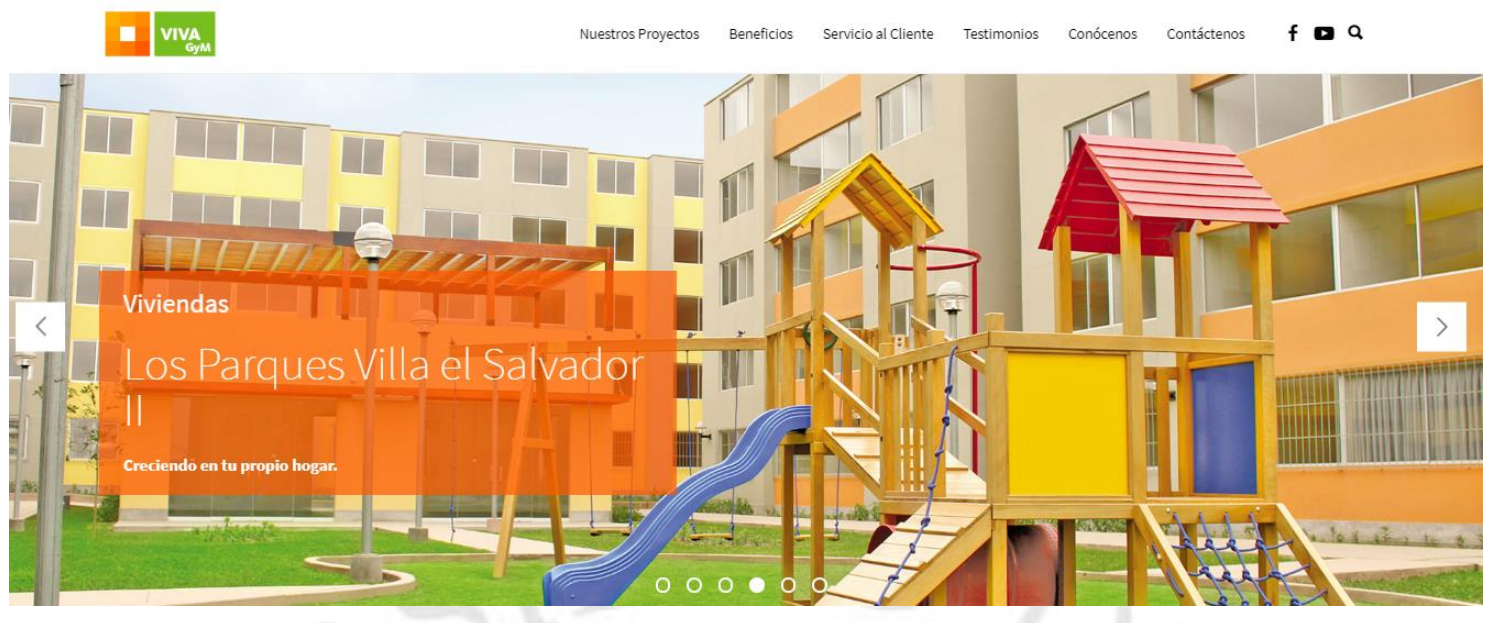

Figura 2: Los parques de Villa el Salvador - Inmobiliaria Viva (http://www.vivagym.com.pe/nuestros-proyectos/proyecto/lpdvillaelsalvadorii)

\section{- Comunicación:}

- La inmobiliaria cuenta con una página web donde presenta sus proyectos en venta, brinda información sobre las características de cada inmueble, los acabados, y la información legal. Además, colocan un formulario donde se puede consultar información sobre el proyecto o solicitar que se comuniquen vía teléfono/correo electrónico.

- La inmobiliaria tiene un Fanpage en el siguiente enlace: https://www.facebook.com/VIVA.GyM/

- La página tiene 111.053 likes.

- La mayoría de sus publicaciones presentan sus distintos inmuebles que se encuentran en venta donde colocan una fotografía atractiva del espacio.

- Algunas publicaciones se enfocan en brindar distintos tips sobre cómo organizar el departamento o de reciclaje.

\section{Proyecto "Paseo La Campiña V"}

La inmobiliaria Arteco tiene el proyecto en venta "Paseo La Campiña V" en Av. Faisanes 356 Urb. La Campiña - Chorrillos. Su precio es desde S/. 201,700 con un área total de $44.50 \mathrm{~m} 2$ hasta $69.10 \mathrm{~m} 2$. Los departamentos son sostenibles y cuentan con el certificado 
de Mi Vivienda Verde por lo que cuentan con el Bono Verde de 3\%, tasa de interés $6.99 \%$ y el financiamiento se realiza con el banco Interbank.

- Departamentos de 3 dormitorios y 2 baños distribuidos en 3 torres con ascensor de última generación

- Áreas comunes como zona de juego para niños, parque interior, zona de parrillas, gimnasio equipado, centro de lavado, salón de usos múltiples, sala de internet

- Condominio con ingreso peatonal y vehicular, acceso controlado y portería las 24 horas del día

La propuesta de valor de la vivienda es ofrecer un "Depa+Club" cerca de todo, con una buena ubicación, excelentes acabados, tecnología ecoamigable, seguridad, diversas áreas comunes y el Bono del 3\% con MiVivienda Verde.

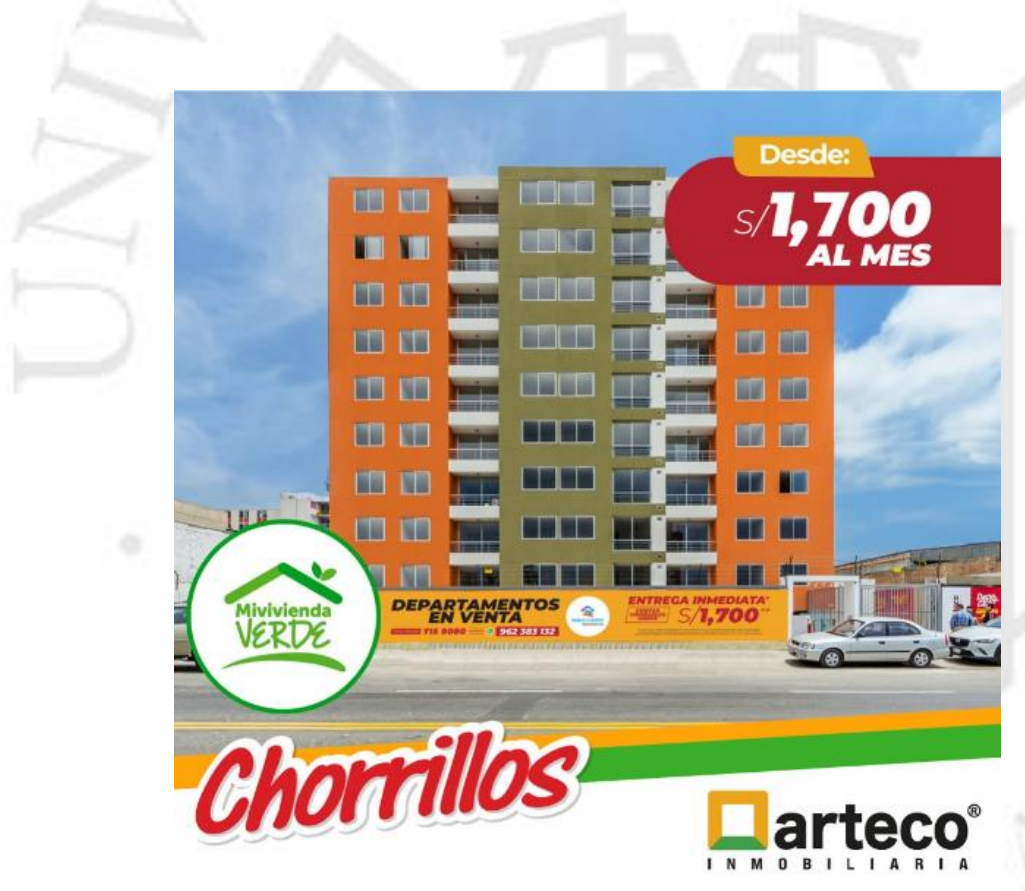

Figura 3: Paseo La Campiña - Facebook Inmobiliaria Arteco

https://www.facebook.com/artecoperu/photos/a.206508992812486/1571464692983569/ ?type $=3 \&$ theater

\section{- Comunicación:}


- Arteco Inmobiliaria tiene una página web en el que colocan toda la información (fotos, videos, brochure) de sus viviendas en los diferentes distritos de Lima y Trujillo.

- También señalan los beneficios que le ofrecen a sus clientes: financiamiento de cuota inicial, asesoría legal, seguridad y áreas comunes

- La red social que utilizan con mayor frecuencia es Facebook y cuenta con 343.011 likes.

- Sus últimas publicaciones son acerca de su presencia en la Feria Nexo Inmobiliaria que se realizó en el Jockey Club y las viviendas que tienen en venta en Chorrillos, Breña, Lince, Huachipa y Trujillo.

\section{Proyecto "Gorriones 3"}

La inmobiliaria Grupo Toscana tiene el proyecto en venta "Gorriones 3" ubicado en Calle Ontario esquina con Avenida El Sol, La campiña - Chorrillos. Los departamentos tienen un precio desde S/. 262,800 desde $71 \mathrm{~m} 2$. Los departamentos pueden financiarse con el Nuevo Crédito MiVivienda y con la entidad financiera BCP.

- 3 bloques de 8 pisos cada uno, siendo en total 117 departamentos, 45 estacionamientos para automóviles y 3 estacionamientos para motocicletas.

- Moderno diseño arquitectónico, elegante lobby de ingreso, amplio estacionamiento, juegos para niños, ambientes para compartir, áreas verdes, gimnasio, estacionamiento para bicicletas, sala de eventos, cámaras de seguridad, vigilancia las 24 horas, cerco eléctrico, zona de parrillas.

- Cerca de centros comerciales, colegios, fácil acceso. 


\section{(T) Grupo Toscana \\ 11 de julio $\cdot(1) \cdot(9)$}

¿Sabías que nuestro edificio \#Gorriones3 tiene múltiples espacios para que pases grandes momentos? ¡Descúbrelos por aqui!

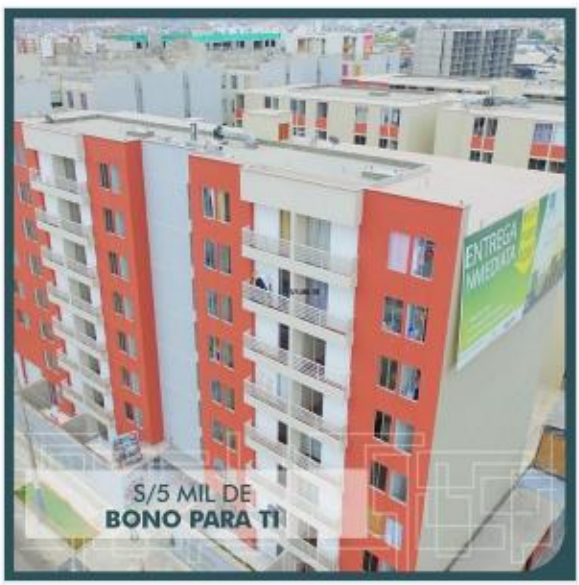

Múltiples espacios para que pases grandes momentos I Gorriones 3

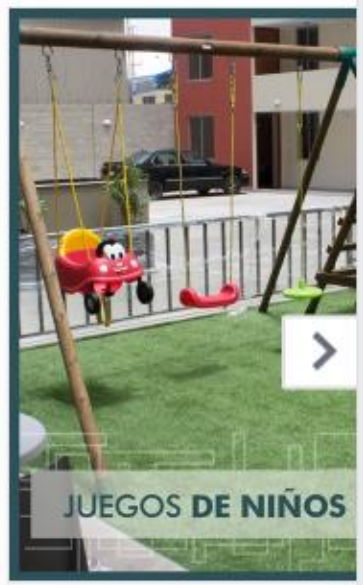

Múltiples espacios para que $\mathrm{p}$ momentos I Gorriones 3

Figura 4: Gorriones 3 - Facebook Grupo Toscana

https://www.facebook.com/pg/grupotoscana/posts/?ref=page_internal

\section{- Comunicación:}

- Grupo Toscana cuenta con una página web donde coloca sus proyectos en venta, terminados y próximos proyectos.

- Cada proyecto está detallado con los ambientes que cuenta, además se incluyen fotos y videos referenciales del edificio y de las zonas comunes.

- Su página de Facebook cuenta con 6,285 likes.

- Sus publicaciones son cada 3 días aproximadamente y su última publicación fue el 12 de setiembre.

- Sus últimas publicaciones son acerca de sus dos inmuebles que se encuentran a la venta en el distrito de Chorrillos: Gorriones 3 y Gorriones 4.

\section{Proyecto "Las Palmas"}


La inmobiliaria Besco cuenta con un proyecto que está próximo a concluir en los siguientes meses. Las Palmas Chorrillos Condominio Ecoamigable se encuentra en Av. Faisanes 345, Chorrillos, el cual tiene departamentos desde 70m2 y precios desde S/. 233.700. Además, cuenta con el Bono Verde de MiVivienda. Las características de este proyecto son:

- 1 edificio de 10 pisos con 100 departamentos, 1 edificio de 10 pisos con 76 departamentos y 1 edificio de 10 pisos con 58 departamentos, haciendo un total de 334 departamentos y 165 estacionamientos techados.

- Departamentos de 2 y 3 dormitorios, ecoamigable, ahorro hasta $30 \%$ en tarifas de agua y luz.

- Cámaras de seguridad, zonas de parrillas, Casa Club, alameda central, circuito deportivo, redes internas para gas, salas de juegos infantiles.

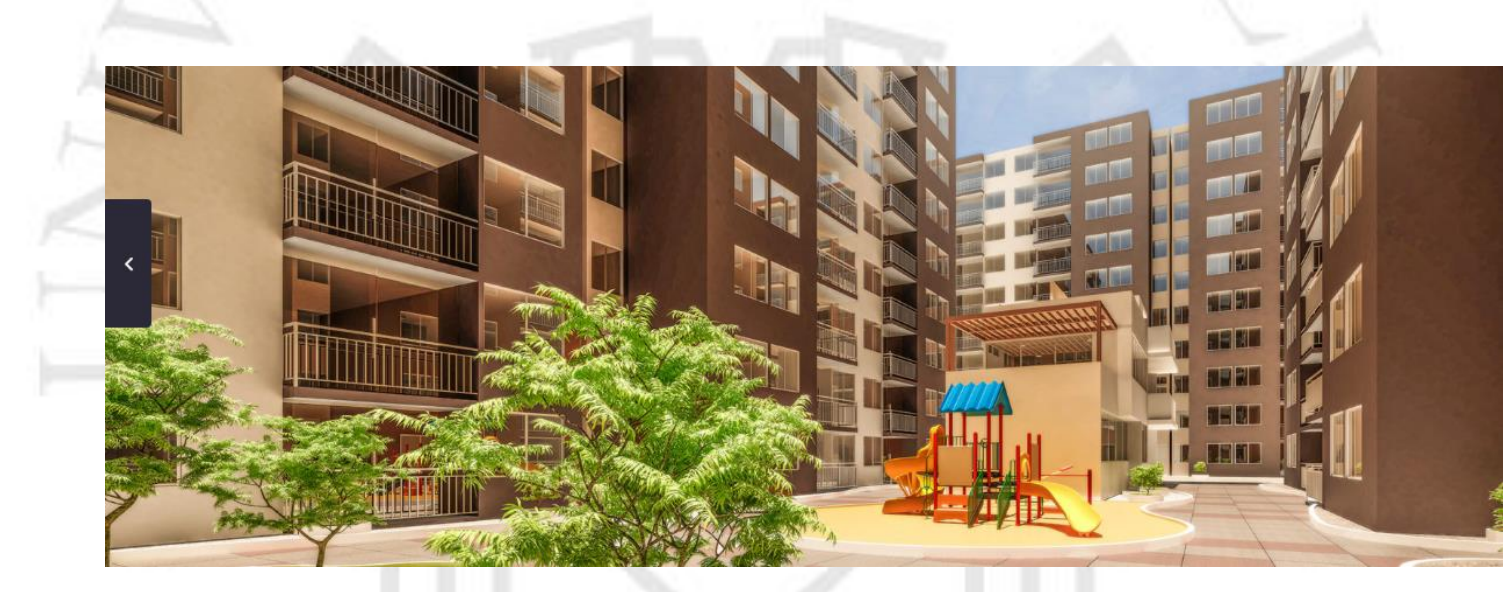

Figura 5: Las Palmas Chorrillos Condominio Ecoamigable - Besco (https://www.besco.com.pe/properties/las-palmas-chorrillos/)

\section{- Comunicación:}

- Besco cuenta con una página web donde brinda información de sus próximos proyectos y los que se encuentran en venta, además indican los beneficios que ofrecen a las familias que deciden adquirir una vivienda con ellos como el Club de Beneficios, Socio Referido y Wasi. Este último es un programa de acompañamiento social de Besco para el desarrollo de la buena convivencia.

- Todos sus proyectos cuentan con los planos de las plantas del inmueble, un tour virtual, fotos y videos de los departamentos 
- Su página de Facebook cuenta con 100.524 likes.

- https://web.facebook.com/BescoPeru/

- Realizan una publicación por día y principalmente son publicaciones sobre la venta de uno de sus proyectos o anunciando uno de sus beneficios Besco al comprar una vivienda. Todas sus publicaciones tienen como imagen a la reconocida actriz Mayella Lloclla.

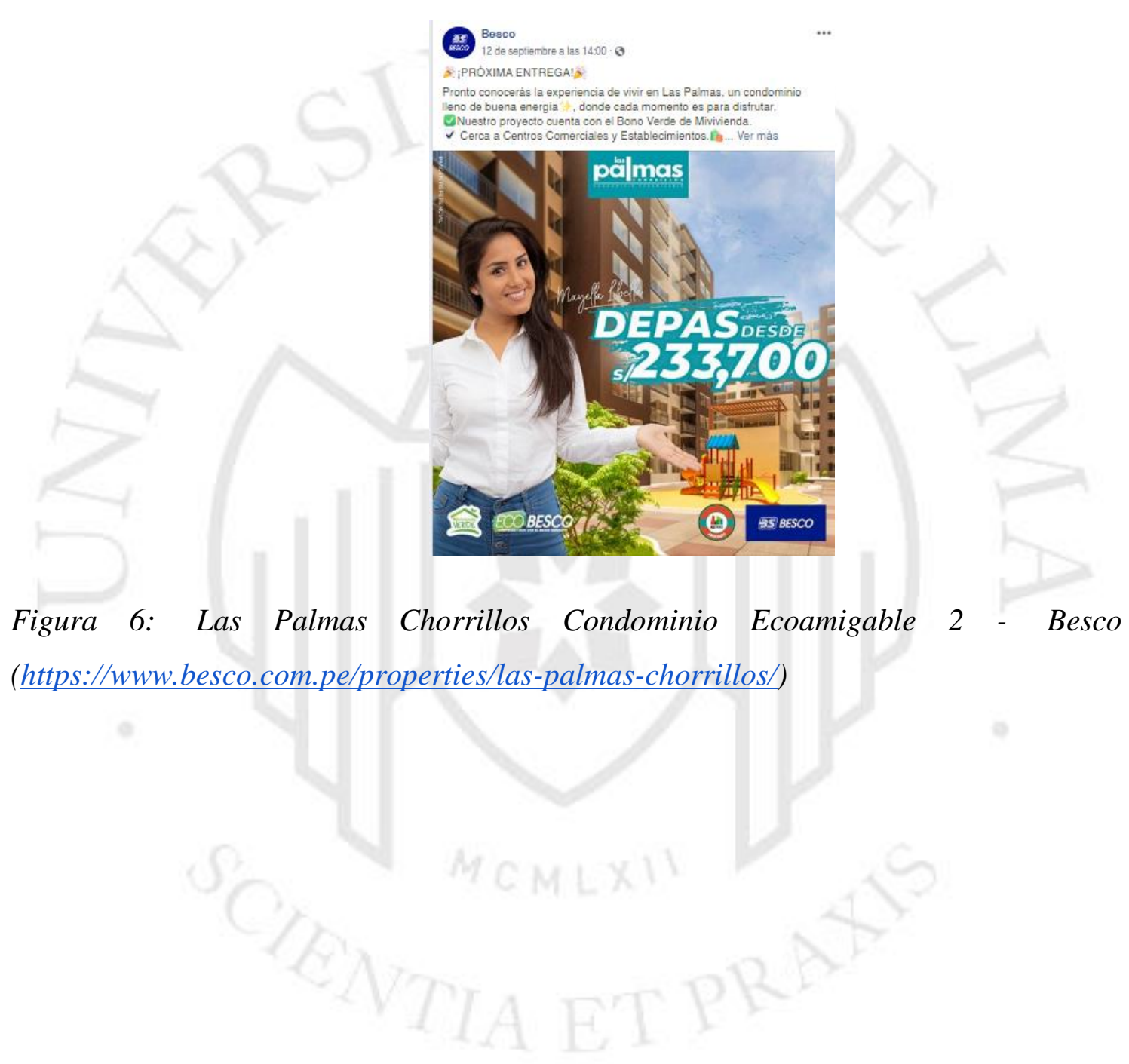




\section{PÚBLICO OBJETIVO}

\subsection{Público objetivo}

La campaña está dirigida a jóvenes y adultos de 25 años a 45 años, pertenecientes al NSE C y NSE D de Lima Sur en búsqueda de comprar una vivienda.

Buyer Persona: Jose Quispe es un hombre de 35 años, casado con 3 hijos, que vive en Villa El Salvador con su familia en un departamento alquilado. Sus hijos tienen 2, 5 y 7 años. Trabaja de manera independiente como dueño de una tienda que vende materiales de construcción. Su ingreso promedio familiar neto mensual es 4000 soles. Tiene secundaria completa, estudió en Villa el Salvador y su empresa se encuentra ubicada en ese distrito. Su esposa trabaja vendiendo menús a trabajadores de fábricas/construcciones, limpiando casas y lavando ropa.

\section{Intereses:}

-Le gusta ver fútbol y jugar partidos con sus amigos. Le gusta pasear en el parque, hacer ejercicios e ir al cine.

\section{Objetivos:}

-Asegurar el futuro de su familia contando con un inmueble propio.

-Independizarse y darle una mejor calidad de vida a su familia.

\section{Desafíos:}

-Encontrar un lugar seguro para que su familia pueda vivir tranquila.

-Ahorrar para poder realizar la compra del inmueble.

-Lograr que sus hijos puedan realizar una educación superior.

\section{¿Cómo podemos ayudar?:}

-Dándole una mejor calidad de vida en una vivienda segura, moderna y accesible. 


\subsection{Tamaño del mercado}

La campaña está dirigida a jóvenes y adultos de 25 años a 45 años, pertenecientes al NSE C y D de Lima Sur en búsqueda de comprar una vivienda.

El proyecto inmobiliario Villa Panamericana se encuentra en Villa El Salvador, distrito perteneciente a la zona Lima Sur, conformada también por los distritos Chorrillos, Lurín, Pachacamac, San Juan de Miraflores y Villa María del Triunfo. En esta zona, el segmento del NSE C conforma el 53.4\% y el NSE D conforma el 27.4\%. El NSE A/B suma $13.3 \%$ y el NSE E, 5.9\%. (CPI, 2019). La información descrita se consolida en el siguiente gráfico:

\begin{tabular}{|c|c|c|c|c|c|c|c|}
\hline \multicolumn{8}{|c|}{$\begin{array}{l}\text { Cuadro } N^{\circ} 11 \\
\text { Lima metropolitana 2019: Estructura socioeconómica de la poblaci }\end{array}$} \\
\hline \multirow[b]{2}{*}{ Zonas } & \multirow[b]{2}{*}{ Distritos } & \multicolumn{2}{|c|}{ Población } & \multicolumn{4}{|c|}{ Estructura socioeconómica (\% horizontal) } \\
\hline & & Miles & $\begin{array}{l}\% \text { sobre } \\
\text { total }\end{array}$ & AB & C & D & $\mathbf{E}$ \\
\hline LIMA NORTE & $\begin{array}{l}\text { Carabayllo, Comas, Independencia, Los Olivos, Puente } \\
\text { Piedra, San Martin de Porres }\end{array}$ & $2,627.6$ & 24.8 & 22.9 & 44.1 & 27.6 & 5.4 \\
\hline LIMA CENTRO & Breña, La Victoria, Lima, Rímac, San Luis & 828.4 & 7.8 & 33.1 & 43.3 & 20.2 & 3.5 \\
\hline LIMA MODERNA & $\begin{array}{l}\text { Barranco, Jesús Maria, La Molina, Lince, Magdalena } \\
\text { del Mar, Miraflores, Pueblo Libre, San Borja, San } \\
\text { Isidro, San Miguel, Santiago de Surco, Surquillo }\end{array}$ & $1,416.0$ & 13.4 & 76.8 & 17.4 & 4.5 & 1.3 \\
\hline LIMA ESTE & $\begin{array}{l}\text { Ate, Chaclacayo, Cieneguilla, El Agustino, Lurigancho, } \\
\text { San Juan de Lurigancho, Santa Anita }\end{array}$ & $2,616.4$ & 24.7 & 17.7 & 45.7 & 29.6 & 7.0 \\
\hline LIMA SUR & $\begin{array}{l}\text { Chorrillos, Lurin, Pachacamac, San Juan de Miraflores, } \\
\text { Villa el Salvador, Villa Maria del Triunfo }\end{array}$ & $1,839.8$ & 17.4 & 13.3 & 53.4 & 27.4 & 5.9 \\
\hline CALLAO & $\begin{array}{l}\text { Bellavista, Callao, Carmen de la Legua Reynoso, La } \\
\text { Perla, La Punta, Mi Perú, Ventanilla }\end{array}$ & $1,100.4$ & 10.4 & 21.7 & 45.9 & 23.6 & 8.8 \\
\hline BALNEARIOS & $\begin{array}{l}\text { Ancón, Pucusana, Punta Hermosa, Punta Negra, San } \\
\text { Bartolo, Santa María del Mar, Santa Rosa }\end{array}$ & 152.4 & 1.4 & 9.7 & 39.9 & 37.7 & 12.7 \\
\hline \multicolumn{2}{|c|}{ TOTAL LIMA METROPOLITANA } & $10,580.9$ & 100.0 & 27.7 & 42.6 & 24.1 & 5.6 \\
\hline
\end{tabular}

FUENTE: APEIM - Estructura socioeconómica 2018

FUENTE: APEIM - Estructura socioeconómica 2018

Tabla 3: Estructura socioeconómica 2018 - CPI

El estudio poblacional 2019 realizado por Ipsos (2019) indica que aproximadamente un $60 \%$ de Lima Sur se encuentra en el rango de edad al que apuntamos, 25 a 45 años.

De acuerdo al informe Perfiles zonales Lima Metropolitana 2019 (Ipsos 2019), existen 476 mil hogares en Lima Sur. El ingreso medio es de 4019 soles. 
Con este dato, determinamos que el NSE C y parte del D tiene la capacidad económica de endeudarse con la compra de un departamento en la Villa Panamericana. Se determinó el ingreso máximo, 6028.5 soles y el ingreso mínimo, 2009.5 soles.

Ingreso máximo: $4019 \times 1.5=6028.5$

Ingreso mínimo: $4019 \times 0.5=2009.5$

Luego, se realizó el cálculo de los ingresos en cuartiles. El ingreso máximo del NSE C es 4336.29 soles y el mínimo es 3701.71 soles. El primer cuartil del NSE D tiene el ingreso promedio de 3490.18 soles. Por lo tanto, entendemos que estos segmentos pueden asumir la deuda de un departamento en Villa Panamericana.

\begin{tabular}{|c|c|c|c|}
\hline NSE & Cuartil & Ingreso promedio del hogar (soles) & Media de ingreso en NSE \\
\hline \multirow[b]{4}{*}{ A } & 1 & 6028.50 & \multirow[b]{4}{*}{5711.21} \\
\hline & 2 & 5816.97 & \\
\hline & 3 & 5605.45 & \\
\hline & 4 & 5393.92 & \\
\hline \multirow[b]{4}{*}{ B } & 1 & 5182.39 & \multirow[b]{4}{*}{4865.11} \\
\hline & 2 & 4970.87 & \\
\hline & 3 & 4759.34 & \\
\hline & 4 & 4547.82 & \\
\hline \multirow[b]{4}{*}{ C } & 1 & 4336.29 & \multirow[b]{4}{*}{4019.00} \\
\hline & 2 & 4124.76 & \\
\hline & 3 & 3913.24 & \\
\hline & 4 & 3701.71 & \\
\hline \multirow[b]{4}{*}{ D } & 1 & 3490.18 & \multirow[b]{4}{*}{3172.89} \\
\hline & 2 & 3278.66 & \\
\hline & 3 & 3067.13 & \\
\hline & 4 & 2855.61 & \\
\hline \multirow[b]{4}{*}{$E$} & 1 & 2644.08 & \multirow[b]{4}{*}{2326.79} \\
\hline & 2 & 2432.55 & \\
\hline & 3 & 2221.03 & \\
\hline & 4 & 2009.50 & \\
\hline
\end{tabular}

Tabla 4: Ingreso medio por NSE - Elaboración propia.

Se puede ver el archivo de Excel en el siguiente link:

https://drive.google.com/file/d/1ElXU776A0BFNX005hiHZf9Osmf6hNklk/view? usp=sh aring 
Según el estudio Perú Situación Inmobiliaria 2017 de BBVA Research, existen 195 mil hogares en Lima que desean adquirir un departamento, sobre todo de precio medio bajo (entre S/. 150 mil y S/.240 mil), lo cual representa el 3,45\% del total de hogares de Lima.

Para obtener esta cifra primero se calculó el total de hogares de Lima considerados en este estudio.

$195000 \times 100 \% / 0,9 \%=2166000$ hogares

De acuerdo a la figura 7 mostrada más adelante, se indica que 74729 hogares están interesados en adquirir una vivienda con valor entre 150 mil y 240 mil soles.

Estos 74729 se dividen entre 2166000 hogares para obtener el 3,45\%

Este es el porcentaje de intención de compra de departamentos de precio medio bajo.

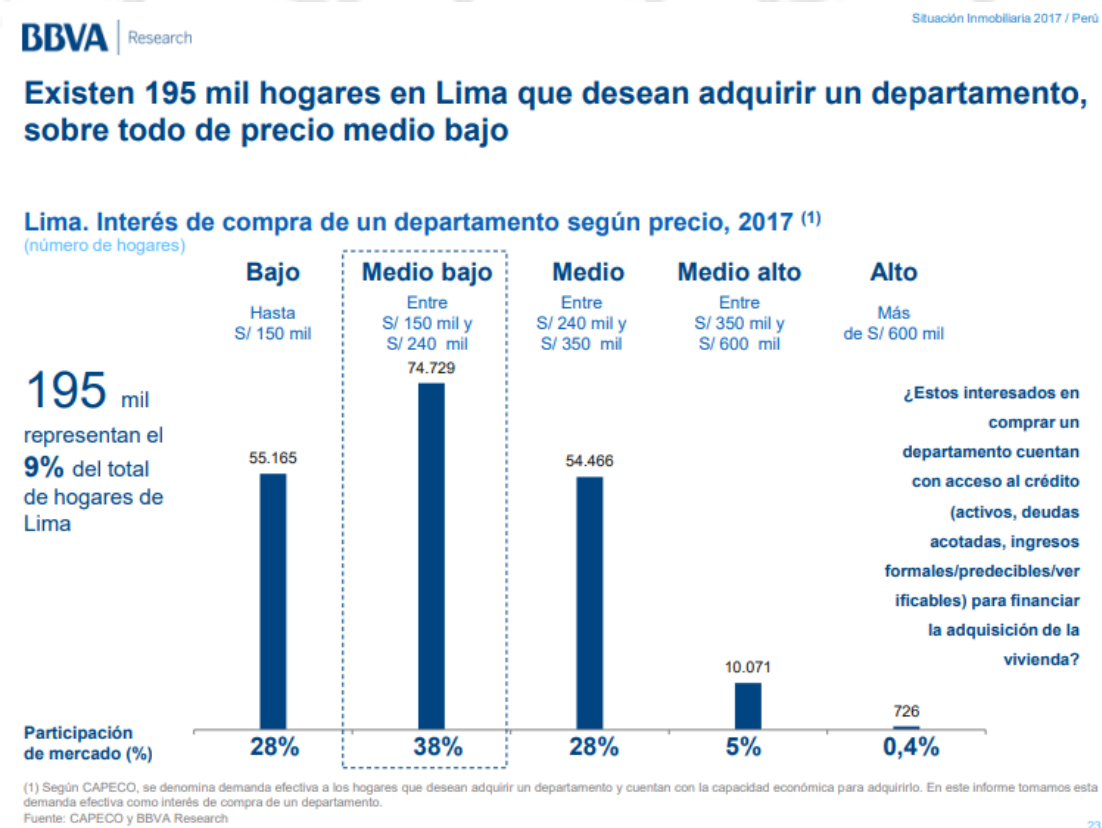

Figura 7: Interés de compra de un departamento - BBVA

Para determinar el tamaño de mercado, se identificó el tamaño de la población de Lima Sur del NSE C y D, cifra que corresponde al 81\% de la población de esta zona, 1490238 personas. Luego se identificó el 60\%, cifra que representa la población de 25 a 45 años. Por último, se calculó la tasa de intención de compra $(3,45 \%)$, dando como tamaño de mercado 35766 personas. El siguiente gráfico muestra los cálculos realizados: 


\begin{tabular}{|c|c|c|c|}
\hline Población Lima Sur & & 1.839 .800 & \\
\hline C & $\mathbf{5 3 , 4 0 \%}$ & & \\
\hline D & $\mathbf{2 7 , 4 0 \%}$ & & \\
\hline Total Población Cy D Lima Sur & $\mathbf{8 1 \%}$ & 1.490 .238 & \\
\hline 25 a 45 años & & & \\
\hline & $60 \%$ & 894.143 & \\
\hline Tasa de Intención & $3,45 \%$ & 30.848 & Tamaño de mercado \\
\hline & & & \\
\hline Total Departamentos a vender & 1042 & & \\
\hline Consultas necesarias por dpto. & 30 & & \\
\hline
\end{tabular}

\section{Tabla 5: Tamaño de mercado - Elaboración propia}

Se puede ver el archivo de Excel en el siguiente link: https://drive.google.com/file/d/1Y2Ub7GkxTVlOqqxW1CXTMmqYWGXzK3h1/view? us p=sharing

\subsection{Embudo de ventas}

El complejo de la Villa Panamericana comprende 1,096 departamentos en total, de los cuales 54 pertenecen a los medallistas de los Juegos Panamericanos, por lo que tenemos 1042 departamentos por vender.

\section{EMBUDO DE VENTAS}

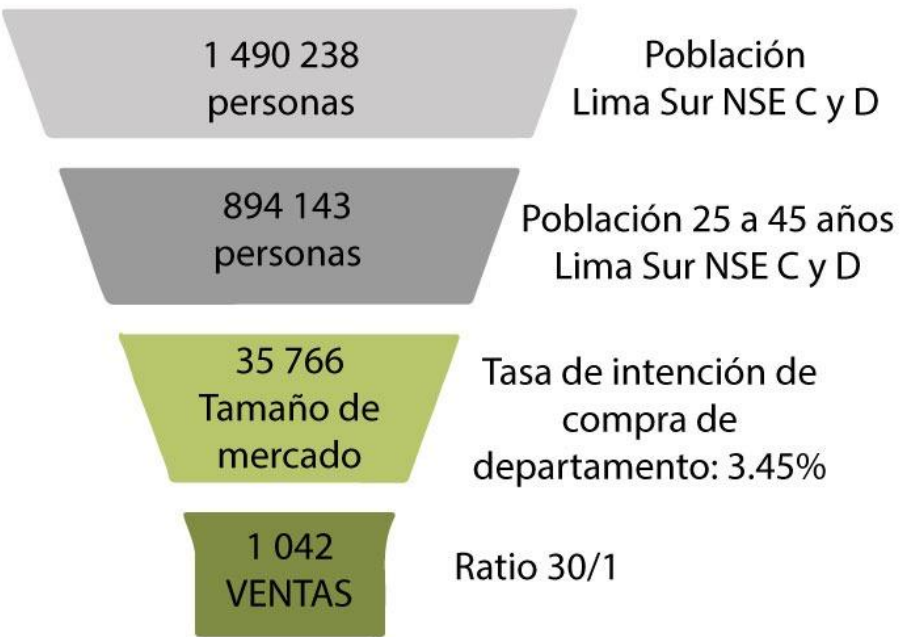

Figura 8: Embudo de ventas - Elaboración propia 
Considerando el tamaño de mercado (35 776 personas), necesitaríamos como mínimo una ratio de 30 personas interesadas por cada departamento disponible.

\subsection{Hallazgos claves}

Se realizaron 113 encuestas a personas de 25 a 50 años residentes de distritos de Lima Sur (Villa el Salvador, Villa María del Triunfo, Lurín, Pachacamac, San Juan de Miraflores y Chorrillos).

El $84.1 \%$ no conoce los beneficios del Nuevo Crédito Mi Vivienda, mientras que el $15.9 \%$ sí lo conoce.

Las personas que afirman conocer sobre el Nuevo Crédito MiVivienda tienen conceptos diferentes:

- Préstamo hipotecario

- Apoyo financiero

- Bono para reducir la cuota del financiamiento bancario

- Subsidio para la compra del primer inmueble

- Préstamo para la adquisición de una vivienda, o mejora de ella.

- Subsidio que ofrece el Estado para que las personas de bajos recursos accedan a créditos inmobiliarios. 


\section{¿Conoces acerca de los beneficios del Nuevo Fondo Mi Vivienda?}
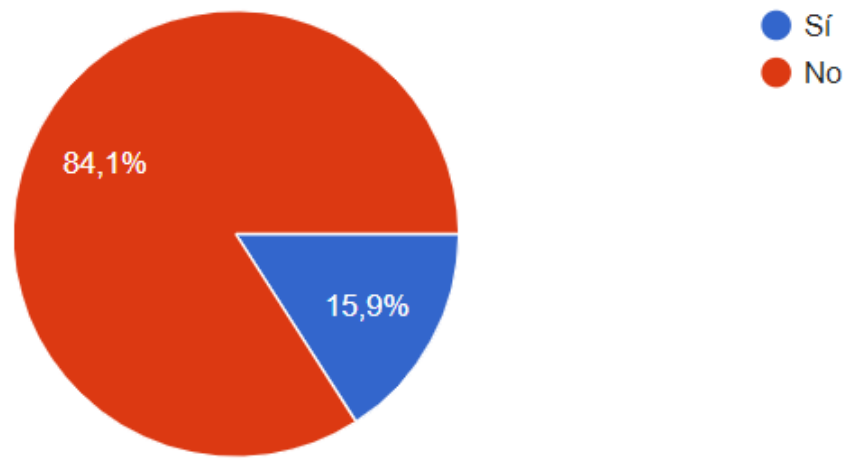

No

Figura 9: Conocimiento del Nuevo Crédito MiVivienda - Elaboración propia

El $87.6 \%$ de encuestados no conoce los beneficios del Bono Verde. El 12.4\% sí los conoce.

Entre lo que entienden los que afirman conocer sobre el Bono Verde está lo siguiente:

- Subsidio por parte del Estado a las instalaciones que cuenten con red interna para gas natural (habilitado).

- Si la propiedad tiene cierto porcentaje de áreas verdes en áreas comunes, el estado te ofrece un bono.

- Subsidio adicional que se otorga en caso el inmueble a adquirir cumpla con determinadas características ecológicas. 


\section{¿Conoces acerca de los beneficios del Bono Verde que ofrece el Estado al comprar}

un inmueble?

\section{3 respuestas}

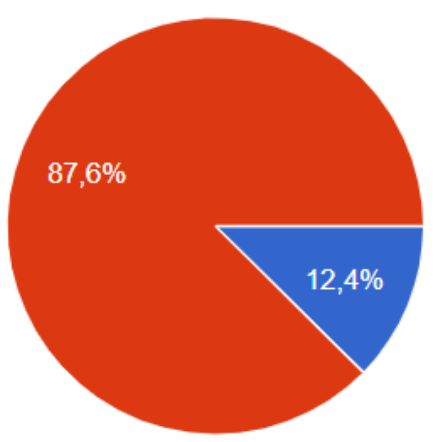

Figura 10: Conocimiento del Bono Verde - Elaboración propia

Podemos concluir, según esta encuesta, que existe poco conocimiento sobre el Nuevo Fondo Mi Vivienda y sobre el Bono Verde. Por lo tanto, la comunicación debe apuntar a explicar de forma clara estos beneficios que otorga el Estado.

Criterios importantes para la compra de una vivienda:

Se pidió a los encuestados que califiquen la importancia de los siguientes criterios para elegir una vivienda, siendo 1 no muy importante y 5 muy importante. Estos fueron los resultados:

1. Seguridad (4,3 de 5)

2. Dimensión del inmueble: número de habitaciones y baños $(3,8$ de 5)

3. Cercanía a centro de estudios y trabajo $(3,7$ de 5$)$

4. Instalaciones con sistema de ahorro de energía y agua (3,6 de 5)

5. Cercanía a paraderos y avenidas principales $(3,4$ de 5$)$

6. Cercanía a centros comerciales y tiendas (3,2 de 5)

7. Cercanía a parques y centros recreativos (3,1 de 5)

8. Áreas comunes: jardín, áreas recreativas, juegos para niños (3,05 de 5)

$\underline{\text { Recordación de Atletas }}$ 
Se preguntó ¿Qué atleta peruano representa para ti mejor la imagen del peruano luchador?

- Gladys Tejeda $92 \%$

- "Piccolo" Clemente 8\%

- Alexandra Grande 0\%

- Christian Pacheco 0\%

- Diego Elías 0\%

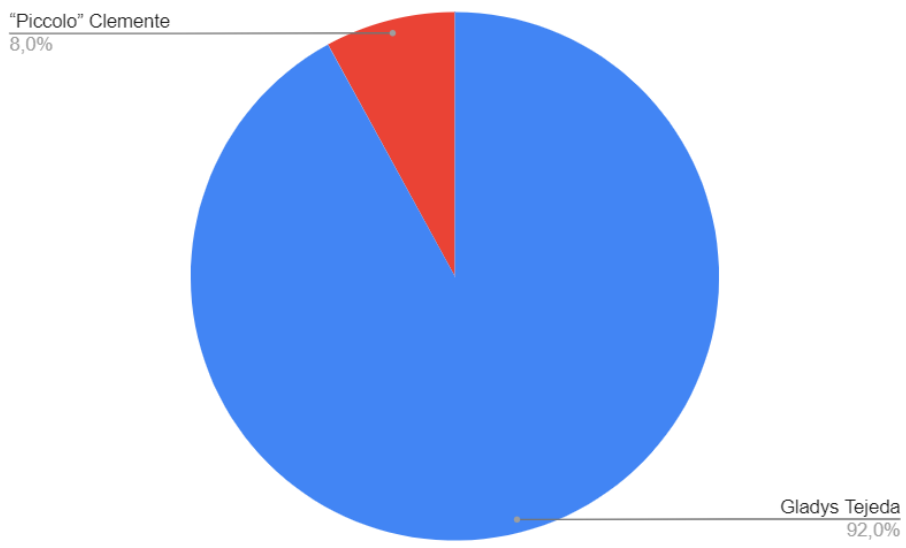

Figura 11: Atleta embajador de marca - Elaboración propia

$\underline{\text { Nombre del condominio }}$

Se colocó opciones para la pregunta ¿Con qué nombre relacionas el condominio que se construyó para hospedar a los atletas de los Juegos Panamericanos y Parapanamericanos en Lima del año 2019?

La gran mayoría seleccionó el nombre "Villa Panamericana".

- Villa Panamericana $98.2 \%$

- Villa de Atletas $1.8 \%$

- Villa de Campeones 0\%

- Villa Deportiva 0\% 


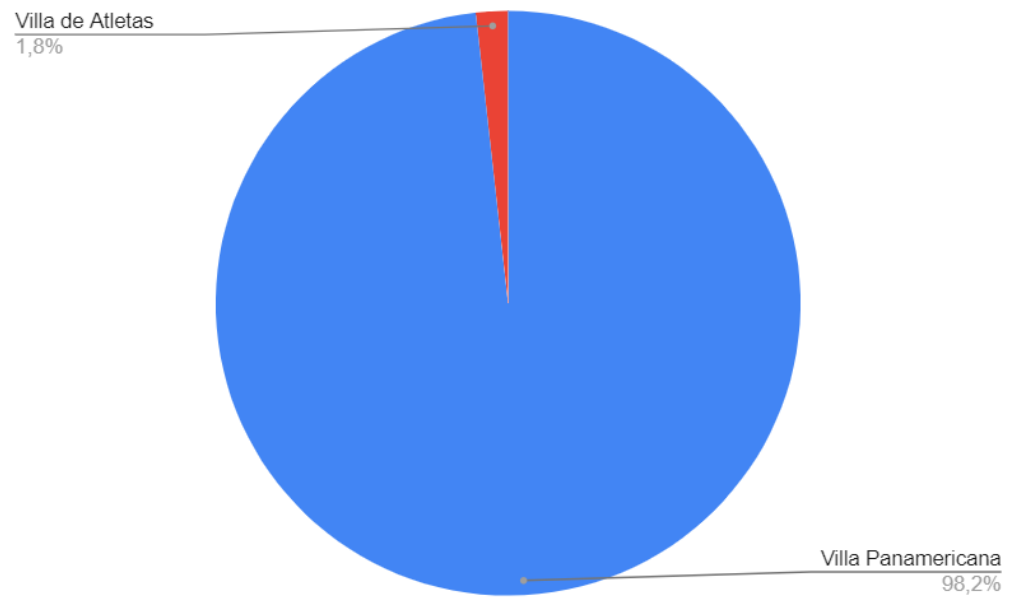

Figura 12: Nombre de condominio - Elaboración propia

\section{$\underline{\text { Isotipo }}$}

Se preguntó ¿Qué isotipo se relaciona más con el condominio donde se hospedaron los atletas para los juegos Panamericanos y Parapanamericanos?

Opción 1: 86,7\%

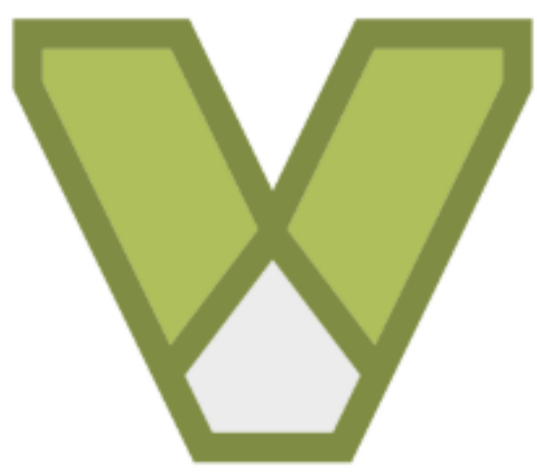

Ilustración 1 - Isotipo Opción 1 - Elaboración propia

Opción 1: 13,3\% 


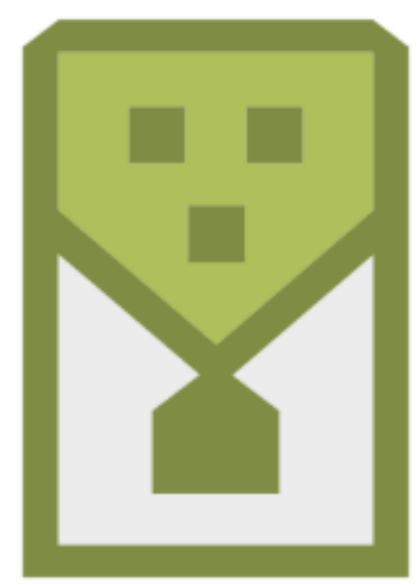

Ilustración 2 - Isotipo Opción 2 - Elaboración propia

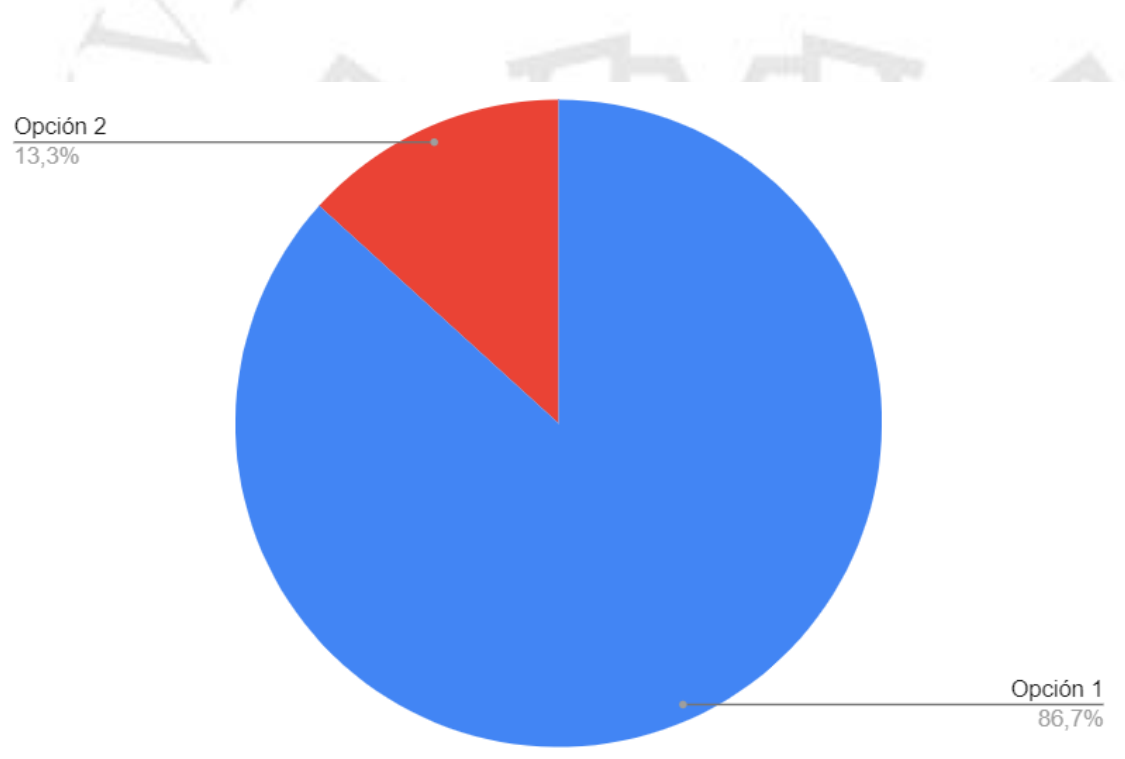

Figura 13: Isotipo - Elaboración propia

\section{Resultados de entrevistas}

Estas son las principales ideas obtenidas en entrevistas a especialistas en marketing del rubro inmobiliario

- Existe garantía por tratarse de un proyecto hecho por el estado y construido por un prestigioso grupo como Consorcio Besco - Besalco.

- El sector C y D es muy incrédulo ante la publicidad, ya que hay muchas estafas por departamentos. Se debe comunicar que es un complejo de viviendas bien construido. 
- Graña y Montero, constructora e inmobiliaria del principal competidor llamado "Los Parques de Villa el Salvador" tiene una crisis de reputación por el caso Odebrecht.

- Vivimos en una ciudad caótica y con mucho tráfico, las áreas verdes y espacios de esparcimiento son importantes para ofrecer tranquilidad cuando se está dentro del complejo.

- Se puede explotar que está en un complejo cerrado, seguro para los niños.

- Hay que comunicar el ahorro de agua y luz.

- Cuando buscas un departamento para vivir buscas avenidas principales, farmacias, clínicas y hospitales, restaurantes y tiendas.

- Se recomienda comenzar con múltiples canales a la vez, sobretodo radio y digital.

- Se recomienda ir a ferias inmobiliarias, ferias en entidades del Estado y ferias en bancos.

- En cada feria se acercan un aproximado de 100 personas a pedir información.

- El Metropolitano es un buen lugar para poner publicidad debido a la gran afluencia de personas que viajan todos los días.

- Llama más la atención colocar el monto mensual a pagar ya que es un número más pequeño que poner el monto final, un número que puede verse abrumador. 


\section{DESARROLLO DE LA CAMPAÑA}

\subsection{Los insights}

En base a las 113 encuestas realizadas a personas que son parte del público objetivo, se obtuvieron principalmente las siguientes respuestas:

- "Para elegir una vivienda lo primordial para mi es la seguridad de la zona".

- "Es muy importante que el lugar donde vivo tenga áreas verdes para pasear con mi mascota".

- "Creo que la ventaja de vivir en un condominio son las zonas comunes como un salón de usos múltiples y juegos para niños".

- "A mi parecer vivir en un condominio cerrado es más seguro porque cuenta con vigilancia".

- "Me interesa que haya vías de acceso y paraderos cerca a donde vivo si es que fuera a comprar una vivienda"

- "Me interesaría vivir en un edificio ecoamigable por el ahorro en energía y agua que significa”.

- "No me gustaría vivir en un piso muy alto por miedo a los temblores y a que se malogre el ascensor".

\subsection{Promesa}

\section{Qué:}

La Villa Panamericana te permite disfrutar de un estilo de vida moderno en un lugar seguro y accesible.

\section{La razón:}

Según el informe "Estadística poblacional 2019” (Ipsos, 2019), en Lima Sur predominan las casas independientes, siendo estas el $88 \%$ del total de viviendas, mientras que las viviendas en edificios representan el 9\%. Es la zona de Lima con menor cantidad de familias viviendo en edificios. Por otro lado, en Lima Moderna predominan los hogares que habitan en edificios, es la zona de Lima con mayor porcentaje de viviendas en edificios $(60 \%)$. 
Vivir en un condominio como el de Villa Panamericana representa un estilo de vida diferente al que predomina en Lima Sur. Un estilo de vida más moderno y cosmopolita, ya que se cuenta con seguridad para el control de entrada y salida de residentes y visitas, áreas verdes y áreas comunes como área de parrilla y juegos para niños en un espacio privado. La construcción de los edificios cuenta con avanzada tecnología ecoamigable que permite ahorrar en el consumo de agua y energía hasta en un 30\%, tiene luces Led y tratamiento de aguas residuales, siguiendo la tendencia del cuidado del medio ambiente a nivel mundial. Además, algunos departamentos cuentan con facilidades para personas con discapacidad y señalización braile. Estas son ventajas que una casa con puerta a la calle no tiene.

Gracias a las facilidades de financiación por el Nuevo Crédito MiVivienda y el Bono MiVivienda Verde, el precio de los departamentos en la VILLA PANAMERICANA es accesible para las familias del NSE C y parte del NSE D, siendo más económico que otros edificios con la misma tecnología y modernidad.

Es un condominio que cuenta con el respaldo de haber sido construido por encargo del Estado al Consorcio Besco-Besalco para un gran evento a nivel internacional: Juegos Panamericanos 2019. Se trata de una constructora seria y de gran prestigio. "Besco está hace 18 años en el Perú y ha construido más de 8,500 departamentos, entre ellos el Complejo de Collique (Comas), que se asemeja a lo que vamos a construir.", indicó Carlos Neuhaus. (El Comercio,2019)

\section{Cómo:}

La comunicación será racional, mostrando los aspectos beneficiosos de un estilo de vida en un condominio moderno y seguro, tomando como argumento las características mencionadas en el punto anterior y las facilidades de financiación. 


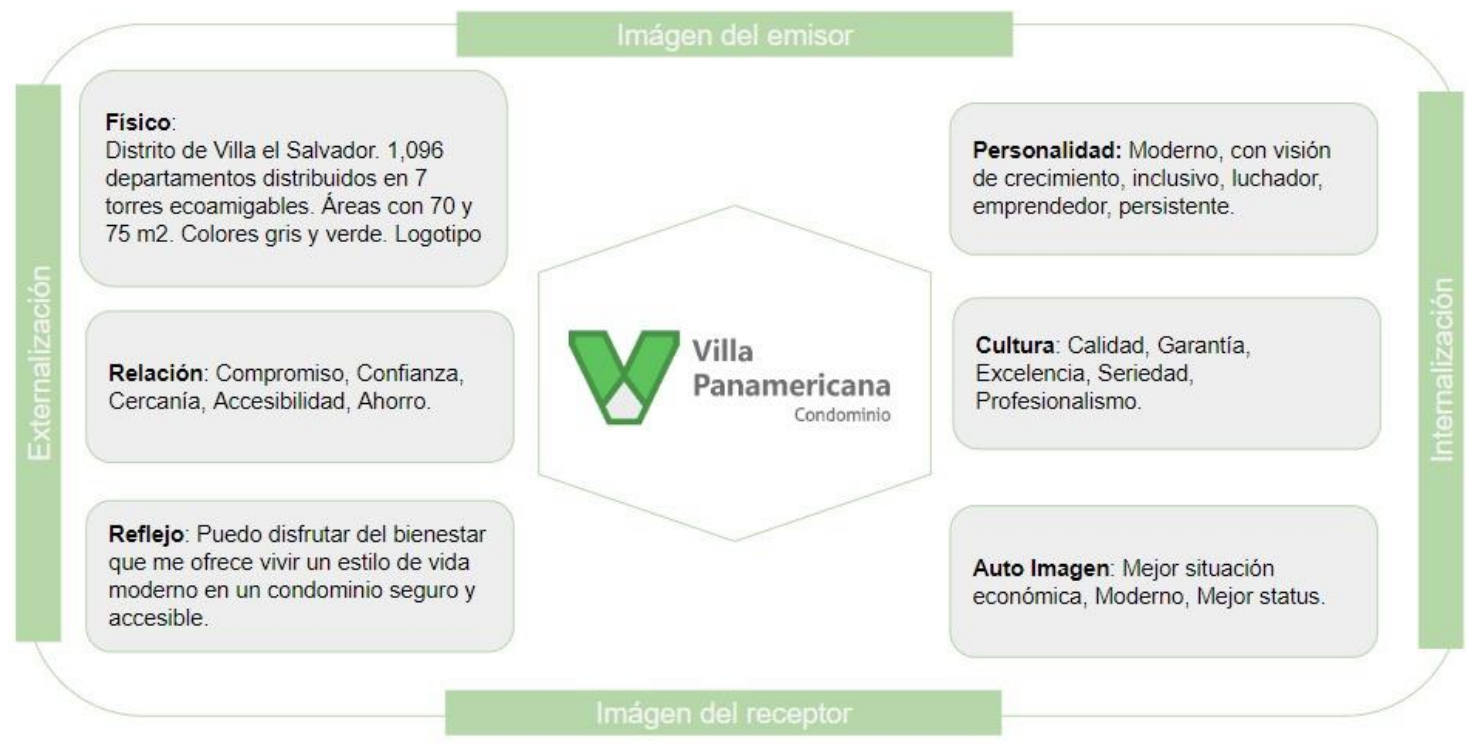

Figura 14: Prisma de Kapferer - Elaboración propia

\subsection{Posicionamiento deseado}

Villa Panamericana es un condominio moderno y seguro ubicado en el corazón de Villa El Salvador a un precio accesible.

\subsection{Propuesta de valor}

Villa Panamericana ofrece un estilo de vida moderno, seguro y accesible para las familias que buscan una vivienda propia en Villa El Salvador.

\subsection{Personalidad}

Moderno, luchador, empeñoso, con visión a futuro, persistente.

\subsection{Tono de la comunicación}

Un lenguaje sencillo, cercano, fácil de comprender y serio, ya que el producto que se ofrece implica una compra grande que va a influir en el resto de la vida del comprador.

\subsection{Nombre y Slogan}


Nombre: Se eligió el nombre "VILLA PANAMERICANA" ya que, según la encuesta realizada, una abrumadora mayoría afirma recordar ese nombre al hablar del condominio donde se hospedaron los deportistas de los Juegos Panamericanos y Parapanamericanos Lima 2019. Además, esta palabra ya tiene un posicionamiento orgánico en las búsquedas de internet más dinámico que "Villa de atletas".

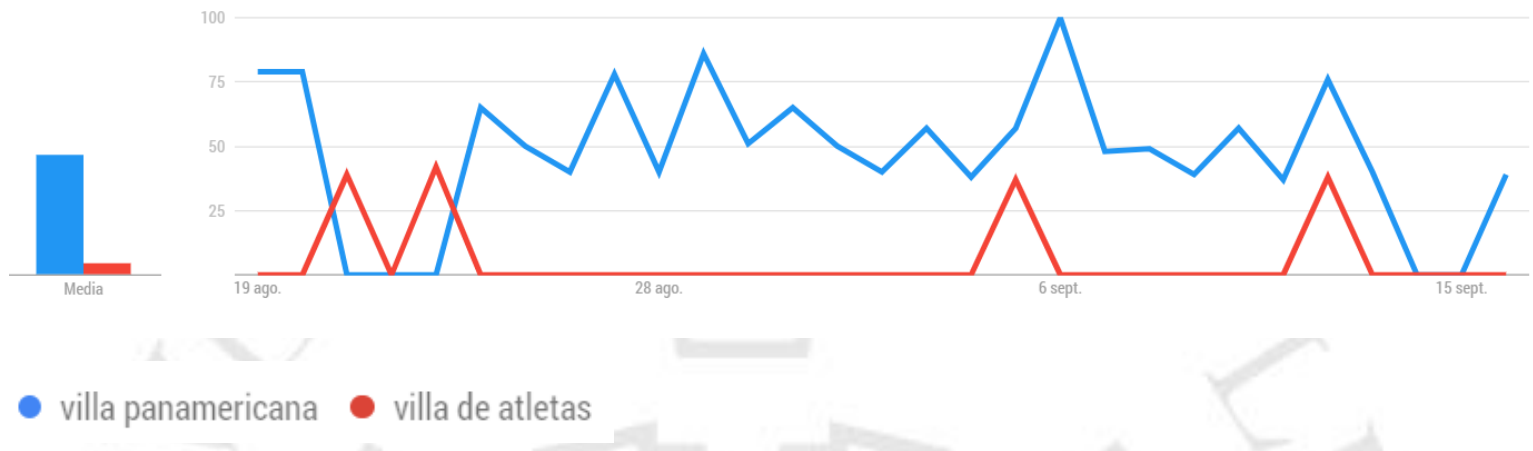

Figura 15: Búsquedas de Villa Panamericana vs. Villa de Atletas - Google Trends

Slogan: "El premio a tu esfuerzo"

Este slogan refuerza la imagen de peruanos luchadores que anhelan un estilo de vida moderno y se esfuerzan por cumplir esa meta. Además, se relaciona con el concepto de premio tanto a los deportistas como el premio que obtiene el comprador por su constante esfuerzo gracias a los beneficios del Nuevo Crédito MiVivienda y el Bono Verde.

\subsection{Identidad visual}

Los colores seleccionados para la marca son VERDE 5FC35D, VERDE 489447, GRIS EDEDED, GRIS 7A797Ay fondo BLANCO \#ffffff

\begin{tabular}{|l|l|}
\hline & Código 5FC35D \\
\hline & Código 489447 \\
\hline & Código EDEDED \\
\hline & Código 7A797A \\
\hline & Código \#fffff \\
\hline
\end{tabular}

Tabla 6 - Códigos de colores - Elaboración propia 
Los tonos de verde representan la característica eco amigable de la construcción, ya que este color evoca a la naturaleza. También representa la tranquilidad porque el verde connota relajación. (Ochoa, 2019).

Los tonos grises y el fondo blanco representan lo moderno, ya que "lo moderno está vinculado a blancos, grises y negros" (Ochoa, 2019). También representa la sobriedad del proyecto y el cemento.

Los tonos de verde se seleccionaron por tratarse de colores encendidos, coherente con el contexto de constructoras e inmobiliarias que, como se puede ver en el siguiente gráfico, usan colores encendidos combinados con colores neutros, como los grises que usamos.

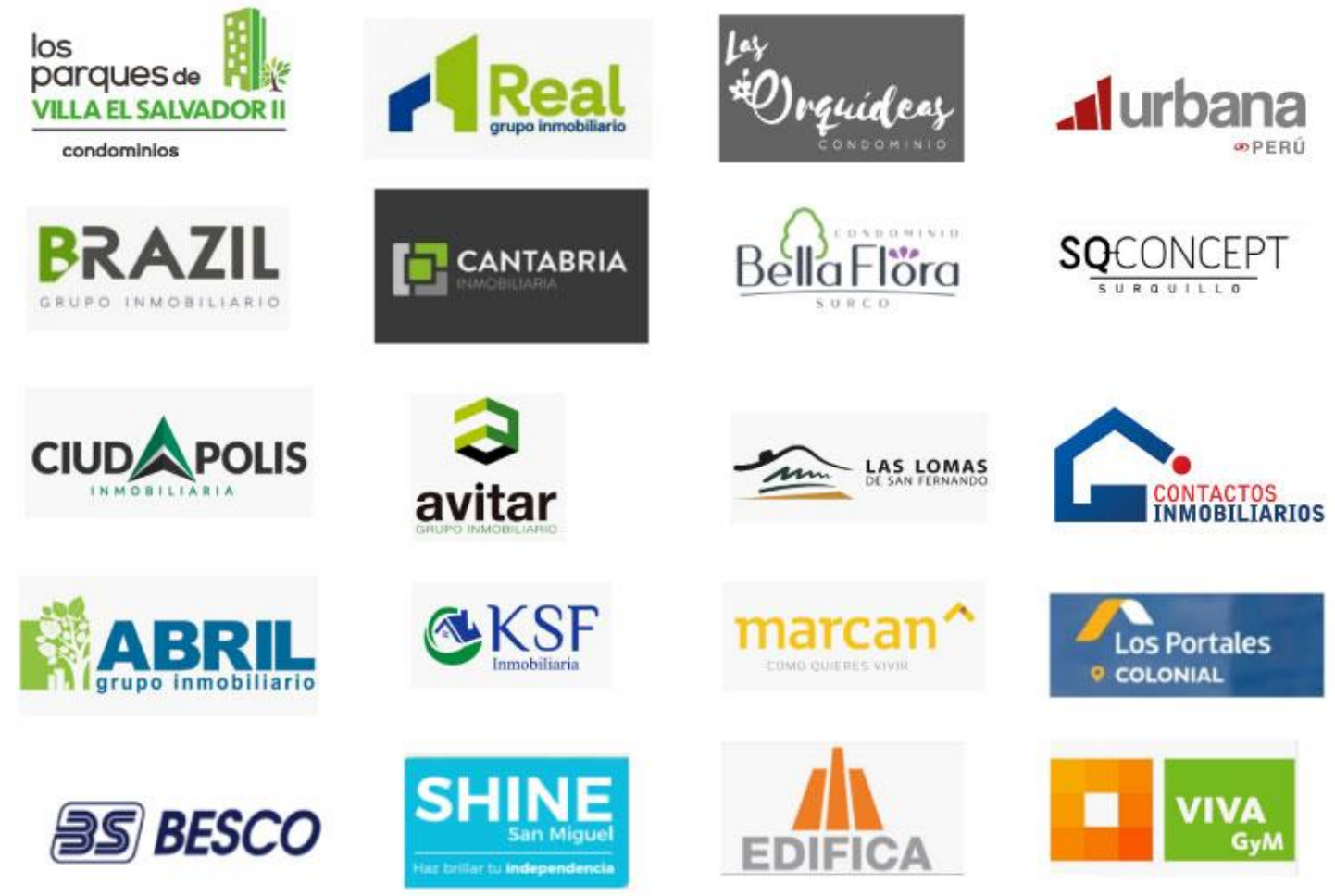

\section{Isotipo: Descripción del concepto}

Los conceptos que se utilizaron para el isologo fueron HOGAR, MEDALLA (éxito), TRATO (Seguridad de una buena compra).

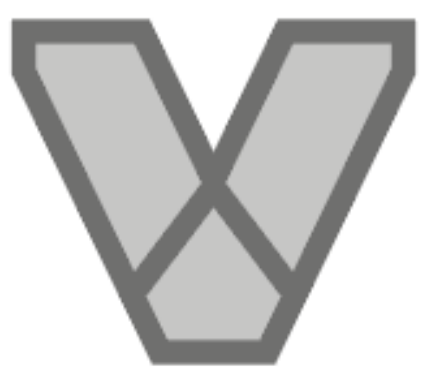




\section{Ilustración 3: Isotipo explicación 1 - Elaboración propia}

El logotipo utiliza las iniciales del proyecto Villa Panamericana, "V" como elemento dentro de su construcción; la forma de la "V" con la intersección al medio también nos remite a las medallas que cuelgan de los atletas ganadores o un apretón de manos al cerrar un trato. Gráficamente esto se relaciona al concepto de marca que hemos utilizado:
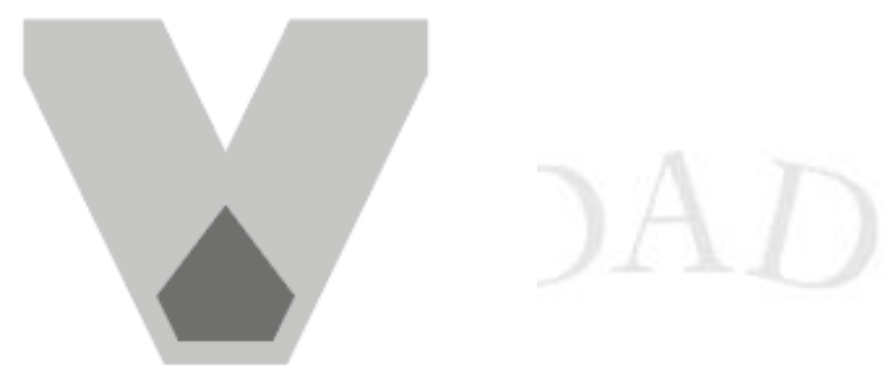

Ilustración 4: Isotipo explicación 2 - Elaboración propia

El vértice hacia arriba nos da paso a la formación de un elemento icónico relacionado al hogar, la casa, esto ayuda a fortalecer el concepto gráfico:
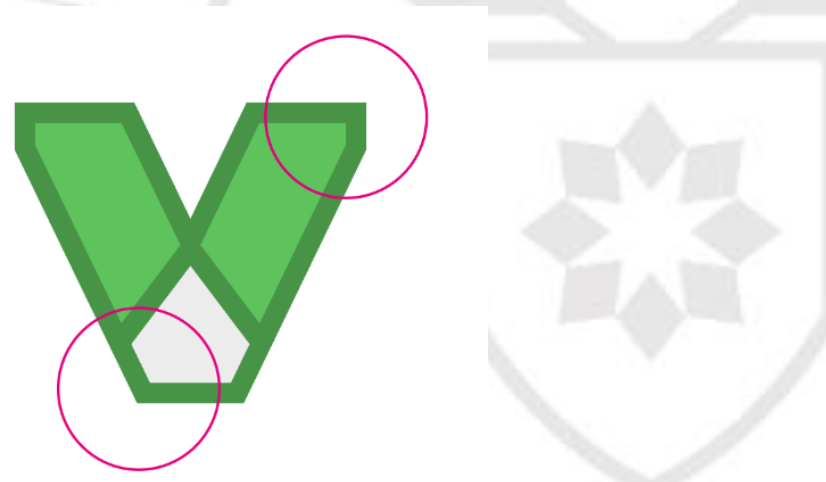

Ilustración 5: Isotipo explicación 3 - Elaboración propia

Las formas biseladas y los vértices son formas duras que se entienden mejor para el rubro de construcción e inmobiliaria además de la paleta de color que nos sugiere consideración por el ambiente. 


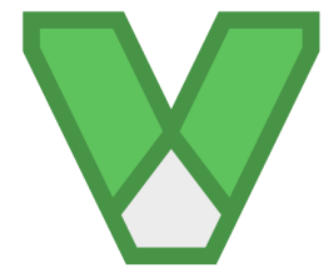

\section{Villa \\ Panamericana}

Condominio

Ilustración 6: Logotipo + descriptor - Elaboración propia

Se utilizó la tipografía "Microsoft yaheiv", una San Serif, la cual connota estabilidad, limpieza y modernidad (Logaster, 2018), además, las líneas rectas de las letras y su grosor connotan la solidez de una edificación.

\subsection{Campaña}

\section{Objetivo de marketing}

Lograr la venta del $100 \%$ de departamentos en el periodo máximo de los primeros seis meses del año 2020.

\section{Objetivo de comunicación}

- Dar a conocer el proyecto y sus características.

- Motivar al target a adquirir uno de los departamentos.

- Comunicar al target acerca de las modalidades de financiamiento a través del programa Mivivienda.

\section{Idea estratégica}

El concepto de nuestra campaña será "Villa Panamericana: el premio a tu esfuerzo", con el que queremos comunicar a nuestro público objetivo que obtener una vivienda moderna, segura y accesible no es lejano para ellos. En realidad, si continúan esforzándose y siendo 
perseverantes, ellos pueden llegar a la meta y obtener el tan ansiado premio: una vivienda propia.

\subsection{Estrategia de medios}

El lanzamiento de la campaña de marketing para la venta de los departamentos empezará el 6 de enero del 2020, esto debido a que el ambiente festivo de Navidad y Año Nuevo ya habrá terminado para ese momento. La fecha de finalización de la campaña será el 28 de junio de 2020.

Consideramos que no es necesario realizar una campaña de intriga, pues la existencia de los departamentos y su destino para venta al público en general ya es de conocimiento de la población a través de los medios de comunicación masiva gracias a la cobertura de los Juegos Panamericanos y Parapanamericanos Lima 2019.

La campaña tendrá dos etapas: (i) Lanzamiento y (ii) Mantenimiento. La primera etapa de Lanzamiento que durará las primeras 8 semanas del año se anunciará la venta de los departamentos a un precio de S/. 186,000.00 donde se buscará abarcar principalmente los medios masivos como televisión, radio y prensa para comunicar el precio por etapa de lanzamiento. En la etapa de Mantenimiento, se buscará generar recordación de marca e incentivar la venta de los departamentos que no se vendieron en la etapa de lanzamiento, la cual se apalancará sobretodo en medios digitales y BTL.

\begin{tabular}{|l|l|l|}
\hline Etapa & Lanzamiento & Mantenimiento \\
\hline Fecha & 6 de enero a 1 de marzo & 2 de marzo a 28 de junio \\
\hline Objetivo & $\begin{array}{l}\text { Generar awareness sobre la venta de los } \\
\text { departamentos y el concepto de la } \\
\text { campaña. }\end{array}$ & $\begin{array}{l}\text { Generar recordación de marca e } \\
\text { incentivar la venta del total de } \\
\text { departamentos que no se vendan en } \\
\text { la etapa de lanzamiento. }\end{array}$ \\
\hline
\end{tabular}




\begin{tabular}{|c|c|c|}
\hline Descripción & $\begin{array}{l}\text { Dar a conocer el lanzamiento de la } \\
\text { venta de departamentos en la Villa } \\
\text { Panamericana y las facilidades de } \\
\text { financiamiento de Nuevo Crédito } \\
\text { MiVivienda y el Bono Verde. }\end{array}$ & $\begin{array}{l}\text { Reforzar principalmente los } \\
\text { beneficios de los departamentos: } \\
\text { modernidad, seguridad y } \\
\text { accesibilidad. }\end{array}$ \\
\hline Medios & ATL, OOH, PR, DIGITAL & ATL, BTL, DIGITAL \\
\hline
\end{tabular}

Tabla 7: Etapas de campaña - Elaboración propia

\subsubsection{ATL}

\section{Televisión}

Se eligió invertir en televisión porque es un medio masivo que cuenta con gran alcance, y que es capaz de transmitir emociones en el receptor a través de una pantalla. Además, según Frutos Torres (2018) "los medios audiovisuales se caracterizan básicamente por la imagen, el sonido, el movimiento en la reproducción del mensaje, que otorgan mayor realismo en la transmisión de los mensajes y son fácilmente procesados”.

Según el informe de Ipsos: Hábitos y actitudes hacia los medios tradicionales (2017), el televidente limeño del NSE C y D representa el 69\% del total de televidentes. Entre los tipos de programas que suelen ver están los noticieros/informativos, películas, deportivos, y telenovelas, mientras que el momento del día en que ven más televisión es al inicio de la noche (8 p.m. - 10 p.m.), siendo el 45\% del NSE C y el 51\% del NSE D. Además, cabe resaltar que América TV es el canal más visto por el NSE C (68\%) y D $(72 \%)$.

El spot de televisión tendrá una duración de 30 segundos, en el cual tendremos como protagonista a nuestra embajadora principal de la campaña: Gladys Tejeda, reconocida deportista y medallista de oro en los Juegos Panamericanos 2019. Ella narrará cuáles son los principales beneficios de vivir en la Villa Panamericana y el financiamiento que se puede obtener con el Nuevo Crédito MiVivienda y el Bono Verde.

\section{Guión técnico}




\begin{tabular}{|c|c|}
\hline Descripción & Audio \\
\hline $\begin{array}{l}\text { Escena 1: Plano Busto de Gladys Tejeda y Plano } \\
\text { General de los edificios de la Villa Panamericana } \\
\text { Texto: Gladys Tejeda - Atleta Olímpica Peruana. }\end{array}$ & $\begin{array}{l}\text { ¿Sabes qué significa para mí } \\
\text { vivir en la Villa } \\
\text { Panamericana? }\end{array}$ \\
\hline $\begin{array}{l}\text { Escena 2: Plano General de Gladys Tejeda, su madre } \\
\text { su hermano y su perro abrazados con el fondo de la } \\
\text { Villa Panamericana. }\end{array}$ & $\begin{array}{l}\text { Darle tranquilidad a mi familia } \\
\text { de vivir en un lugar seguro. }\end{array}$ \\
\hline Escena 3: Primer Plano de un foco led encendiéndose. & $\begin{array}{l}\text { Poder ahorrar hasta un } 30 \% \text { en } \\
\text { nuestras tarifas de luz y agua. }\end{array}$ \\
\hline $\begin{array}{l}\text { Escena 4: Primer Plano de las manos lavándose en el } \\
\text { caño }\end{array}$ & $\begin{array}{l}\text { Ya que los departamentos } \\
\text { cuentan con infraestructura } \\
\text { eco amigable. }\end{array}$ \\
\hline $\begin{array}{l}\text { Escena 5: Plano General de tiendas, restaurantes, } \\
\text { MegaPlaza, Makro. }\end{array}$ & $\begin{array}{l}\text { Estar a un paso de muchas } \\
\text { tiendas, restaurantes y centros } \\
\text { comerciales. }\end{array}$ \\
\hline $\begin{array}{l}\text { Escena 6: Plano Medio de Gladys Tejeda paseando } \\
\text { por las áreas verdes del Condominio }\end{array}$ & 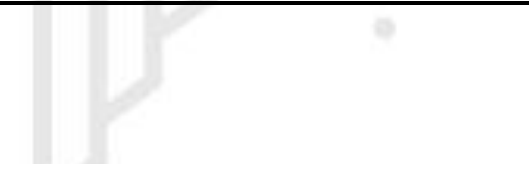 \\
\hline $\begin{array}{l}\text { Escena 7: Plano General de Gladys Tejeda manejando } \\
\text { bicicleta en ciclo vía dentro del Condominio }\end{array}$ & y la naturaleza. \\
\hline $\begin{array}{l}\text { Escena 8: Plano General de niños corriendo en los } \\
\text { juegos del condominio Villa Panamericana }\end{array}$ & $\begin{array}{l}\text { Es pensar en el futuro de mi } \\
\text { familia. }\end{array}$ \\
\hline $\begin{array}{l}\text { Escena 9: Primer Plano de una mano entregando las } \\
\text { llaves a otra mano. }\end{array}$ & $\begin{array}{l}\text { Villa Panamericana... es el } \\
\text { premio a tu esfuerzo. }\end{array}$ \\
\hline $\begin{array}{l}\text { Escena 10: Gladys Tejeda plano busto, } 3 / 4 \text { dentro de } \\
\text { una sala de estar. }\end{array}$ & $\begin{array}{l}\text { Múdate a un precio accesible } \\
\text { gracias al financiamiento del }\end{array}$ \\
\hline
\end{tabular}




\begin{tabular}{|l|l|}
\hline $\begin{array}{l}\text { Aparece en pantalla el logo de Nuevo Crédito } \\
\text { MiVivienda y logo de Bono MiVivienda Verde. }\end{array}$ & $\begin{array}{l}\text { Nuevo Crédito MiVivienda y } \\
\text { el Bono Verde. }\end{array}$ \\
\hline $\begin{array}{l}\text { Escena 11: Aparece en pantalla el Logo Villa } \\
\text { Panamericana y Texto: Encuentra más información } \\
\text { en www.villapanamericana.gob.pe o llamando al }\end{array}$ & iCorre por tu depa! \\
0800-11800. & \\
\hline
\end{tabular}

Tabla 8: Guion técnico de spot publicitario - Elaboración propia

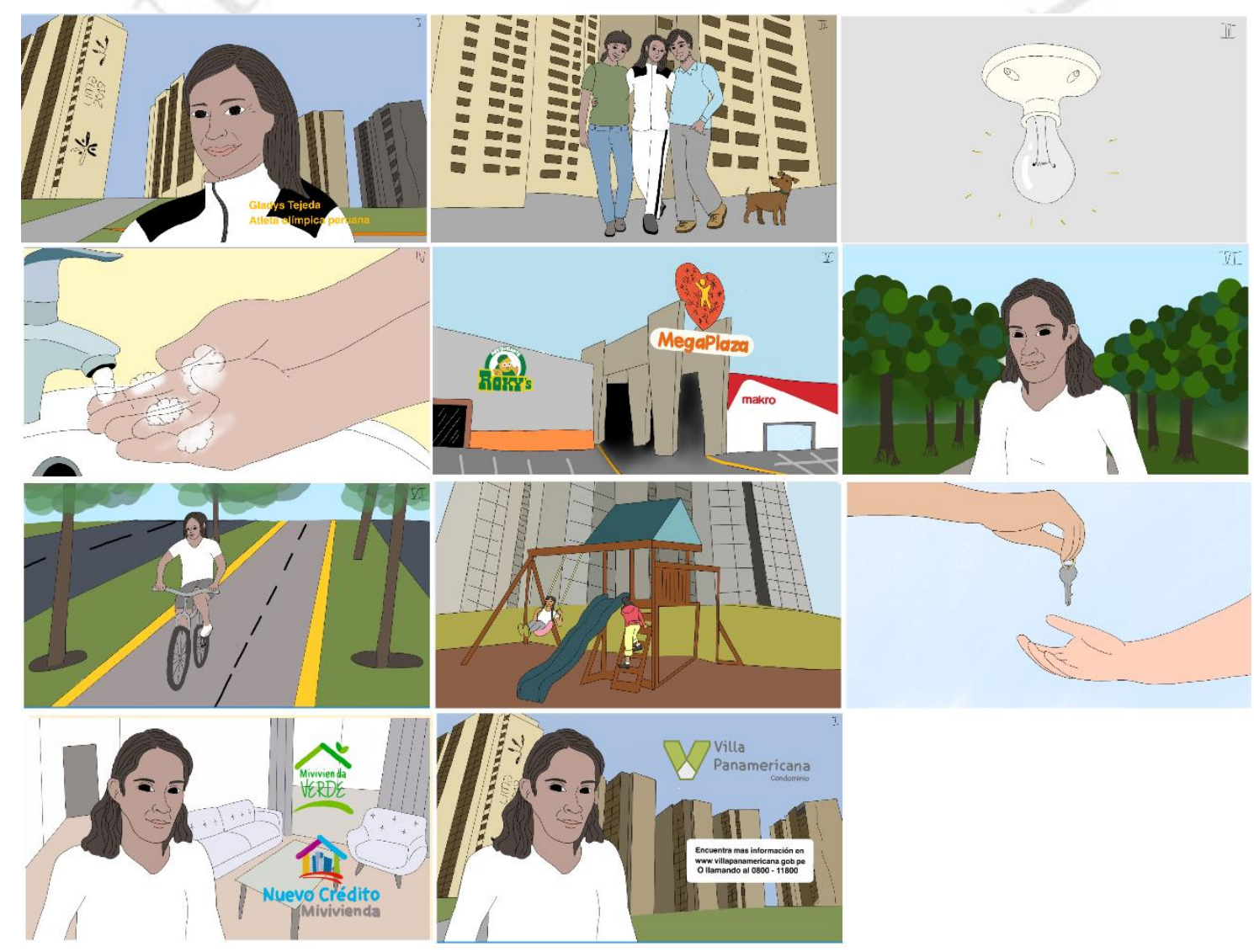

Ilustración 7: Storyboard - Elaboración propia

El spot publicitario se publicaría en señal de América Televisión, en horario súper prime, en la sección de comerciales de los programas "América Noticias Edición Central Noche" y "Fútbol en América" Dichos programas son los que cuentan con mayor alcance para 
nuestro público objetivo. Por otro lado, al ser un proyecto a manos del Estado, se podrá colocar en el canal Tv Perú, ya que es el canal donde se da la mayor cobertura informativa del país y se difunden sus proyectos.

De igual manera, realizaremos "product placement" en la novela "En la piel de Alicia", la cual se transmite de lunes a viernes de 9:30 p.m. a 10:30 p.m. y cuenta con el mayor rating en su horario en el segmento NSE C, D y E según TV Data. Además, está ambientado en la actualidad, a diferencia de la otra telenovela líder en América TV, "De vuelta al Barrio", la cual se ambienta en el pasado.

Se presentará el condominio Villa Panamericana como parte del capítulo final de la telenovela. El personaje Richi quiere sorprender a su enamorada Alicia con un departamento que será su nueva vivienda juntos. Él y su hermano van a visitar la Villa Panamericana, donde un agente de ventas les muestra el condominio, las áreas comunes, la moderna infraestructura. Luego, en casa de Alicia, él le dice que ha comprado un departamento, y le comenta que lo pagará en cuotas gracias al financiamiento del banco, el Nuevo Crédito MiVivienda y el Bono Verde. Finalmente, se les ve caminando por las áreas verdes del condominio y decorando su nuevo departamento.

\section{Inversión total Televisión: S/. 213458.41 (Doscientos Trece Mil Cuatrocientos} Cincuenta Y Ocho con 41/100 Soles).

\section{Radio}

Según el informe de Ipsos: Hábitos y actitudes hacia los medios tradicionales (2017), el radioyente limeño del NSE C y D representa el $68 \%$ del total de radio oyentes. Según Frutos Torres (2018), "los receptores lo perciben como un medio cercano, fomentado por la intimidad que se establece entre el locutor y el oyente". A través de este medio, buscamos acercarnos a nuestro target a través de una comunicación sencilla, cercana y fácil de comprender.

En la etapa de Lanzamiento, la cual tendrá como duración las primeras ocho semanas de la campaña, el spot destinado para la radio tendrá una duración de 20 segundos y será grabado con la voz de la deportista Gladys Tejeda, se busca crear awareness sobre el 
lanzamiento de la venta de los departamentos de la Villa Panamericana y dar a conocer que existen los beneficios del financiamiento del Nuevo Crédito MiVivienda y El Bono Verde, esta información se brindará gracias al call to action hacia la página web o el número telefónico.

La etapa de Mantenimiento tendrá como duración nueve semanas de la campaña desde abril a mayo. El spot de radio de 20 segundos tendrá como protagonista a Jorge Arcela, medalla de plata en los Juegos Parapanamericanos, quien transmitirá y reforzará en esta etapa los mensajes claves de seguridad, modernidad y accesibilidad de los departamentos. Las emisoras que se seleccionaron de acuerdo al público objetivo que nos dirigimos son las siguientes:

- RPP (FM): Es la radio informativa líder en el Perú y cuenta con la mayor cantidad de radio oyentes en Lima. (CPI, 2018) La elegimos porque es la que cuenta con mayor credibilidad y seriedad, por lo que es ideal para comunicar la venta de los departamentos en la primera etapa.

- Karibeña: Se eligió esta radio porque es la tercera con más radio oyentes en Lima y tiene más afinidad al target que nos dirigimos que se encuentra en los NSE C y D. Además, es una radio donde colocan música cumbia, uno de los géneros más escuchados por nuestro público objetivo. (Ipsos, 2017)

- Panamericana: Es una emisora emblemática que tiene gran audiencia y apunta a hombres y mujeres de 26 a 50 años. Los géneros que transmiten son salsa, bachata y tropicales, por lo que es acorde al público que buscamos llegar.

\section{Guion de radio}

\section{(Voz: Gladys Tejeda)}

"Hola, soy Gladys Tejeda. ¿Aún no encuentras el depa de tus sueños? ¡El condominio

Villa Panamericana tiene todo lo que necesitas! Aprovecha los beneficios del Nuevo

Crédito MiVivienda y el Bono Verde. La Villa Panamericana es el premio a tu esfuerzo ¡Corre por tu depa!

Encuentra más información en villapanamericana punto gob punto pe o llama al 080012200. 


\section{(Voz: Jorge Arcela)}

"Soy Jorge Arcela, medalla de plata Para Tiro de 10 metros en los Juegos Parapanamericanos. Desde que vivo en la Villa Panamericana tengo la tranquilidad de estar en un lugar seguro, moderno y con diversas áreas comunes. ¡Premia tu esfuerzo y múdate tú también!"

Encuentra más información en villapanamericana punto gob punto pe o llama al 080012200.

Inversión total Radio: S/. 79,060.00 (Setenta Y Nueve Mil Sesenta con 00/100 Soles).

\section{OOH}

Se eligió este medio, ya que es de gran alcance y de bajo costo, por lo que se puede aprovechar en colocar publicidad en puntos estratégicos cerca de la zona y distritos aledaños a la Villa Panamericana. Según el estudio de Ipsos: Hábitos y actitudes hacia los medios de comunicación alternativos (2015), el 61\% de personas del NSE C que viven en Lima Metropolitana van mirando la publicidad en las calles cuando se transportan, en el NSE D, corresponde al $71 \%$.

Según la data proporcionada por la empresa GPO Vallas, el tiempo de atención visual de un usuario regular en transporte público es en promedio de 0.96 segundos con un máximo de 3.43 segundos. En el caso de copiloto, el promedio de atención visual es de 0,4 segundos con un máximo de 1,7 segundos.

En la etapa de Lanzamiento, se colocarán paneles comunicando la venta de los departamentos, una referencia de las cuotas mensuales, y un call to action para que puedan ingresar a la página web o llamar al teléfono de ventas donde podrán encontrar mayor información. Se colocarán en la zona Lima Sur, principalmente en los distritos de Villa El Salvador, San Juan de Miraflores, Villa María del Triunfo y Lurín. En Villa El Salvador, colocaremos un panel en la Avenida Mariano Pastor, la cual se encuentra a dos cuadras de la Villa Panamericana. Esta avenida es un punto que cuenta con elevado nivel 
de tránsito, ya que se encuentra a unas pocas cuadras de la carretera Panamericana Sur, UTP, Universidad Autónoma del Perú y Makro.

Asimismo, aprovecharemos en colocar publicidad en paneles en distritos aledaños como San Juan de Miraflores (Av. Los Héroes, Puente Atocongo) y Villa María del Triunfo (Av. Pachacutec cruce con Av. 26 de Noviembre). Ambos se encuentran en zonas cerca a centros comerciales y zonas comerciales con gran tránsito. Además, colocaremos un panel en Lurín, ya que es una ubicación donde se encuentra una gran cantidad de fábricas, por lo que podemos llegar a los trabajadores de esa zona.

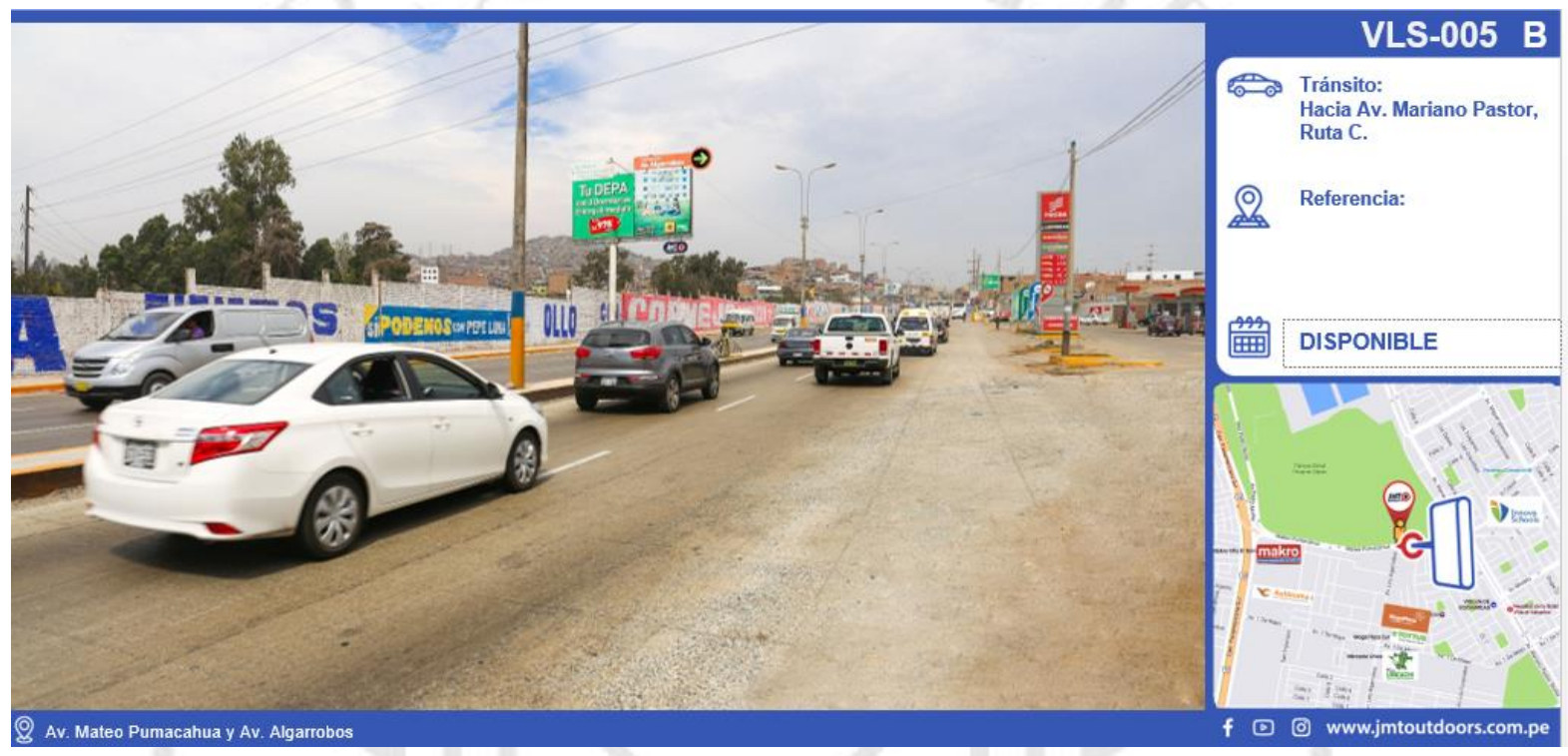

Figura 16: Panel en Av. Mariano Pastor - Villa El Salvador. Fuente: JMT

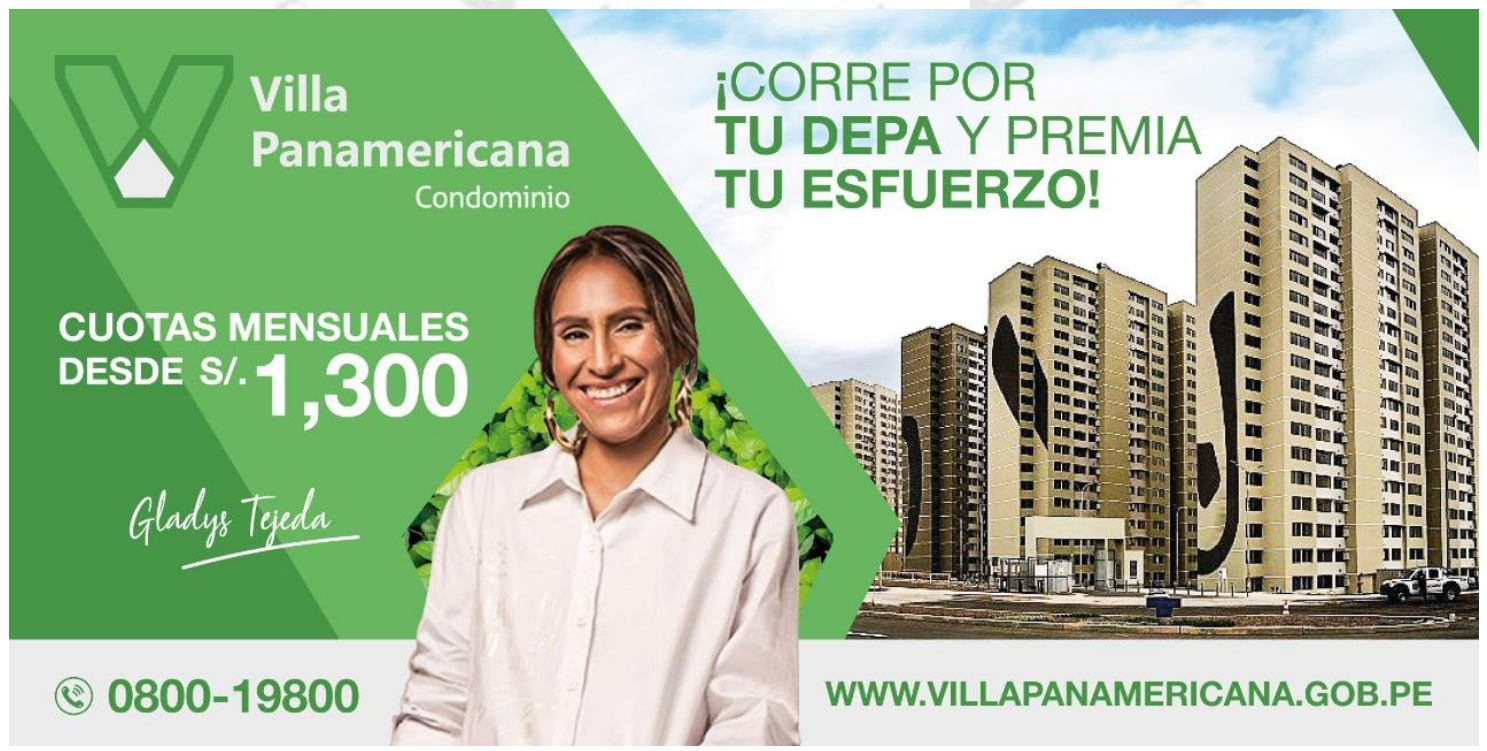




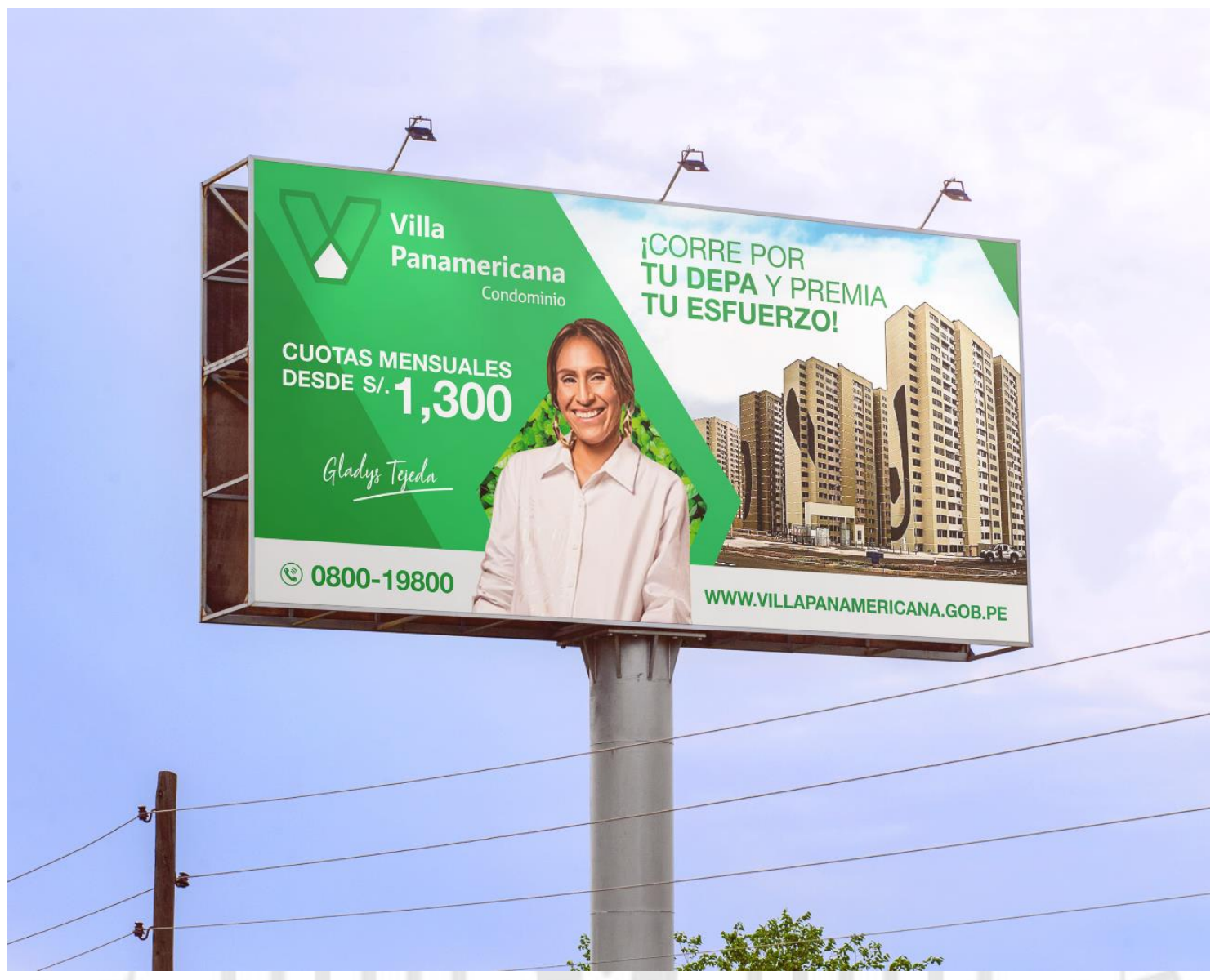

Ilustración 9: Diseño de valla publicitaria 2 - Elaboración propia

\section{OOH - Metropolitano}

La empresa Efectimedios Perú es la encargada de administrar la publicidad en el Metropolitano de Lima, medio de transporte de alta afluencia de público que se transporta de Lima Sur a las demás zonas de Lima.

Afirman en su brochure que el tiempo de espera de los pasajeros para abordar el transporte permite que estos aprecien mejor los mensajes de la publicidad. El $41 \%$ de su público objetivo es del NSE C, el 3\% es del NSE D. El 57\% son trabajadores, es decir, pertenecen a la población económicamente activa. 


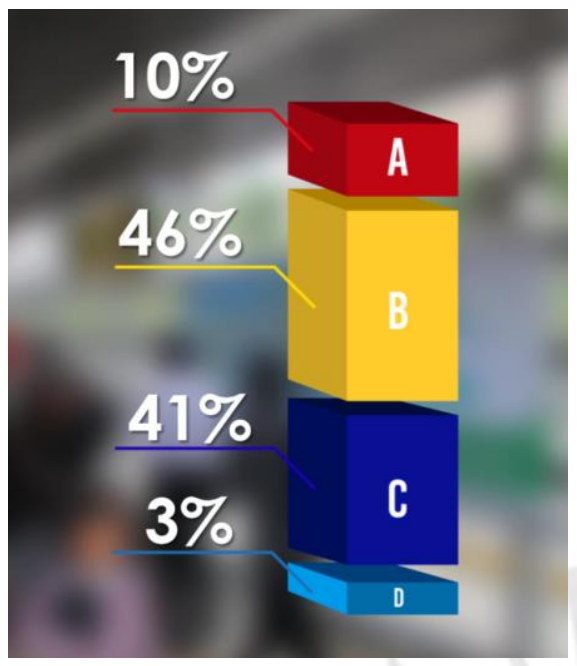

Figura 17: NSE de usuarios del Metropolitano - Efectimedios Perú

\section{Alimentador Lima Sur Metropolitano}

Se colocará publicidad en los dinteles del alimentador de Lima Sur, zona en la que se encuentra la Villa Panamericana. Se publicará en este espacio por los meses de la etapa de mantenimiento de campaña de abril a junio. En esta etapa, se reforzarán los mensajes claves de seguridad y modernidad, colocando imágenes de áreas comunes o zona de juegos en la que una familia está disfrutando con los edificios de fondo, con el logo de la Villa Panamericana y el texto “ $; C$ Corre por tu depa! Seguridad y modernidad a tu alcance”, indicando la dirección de la página web y teléfono.

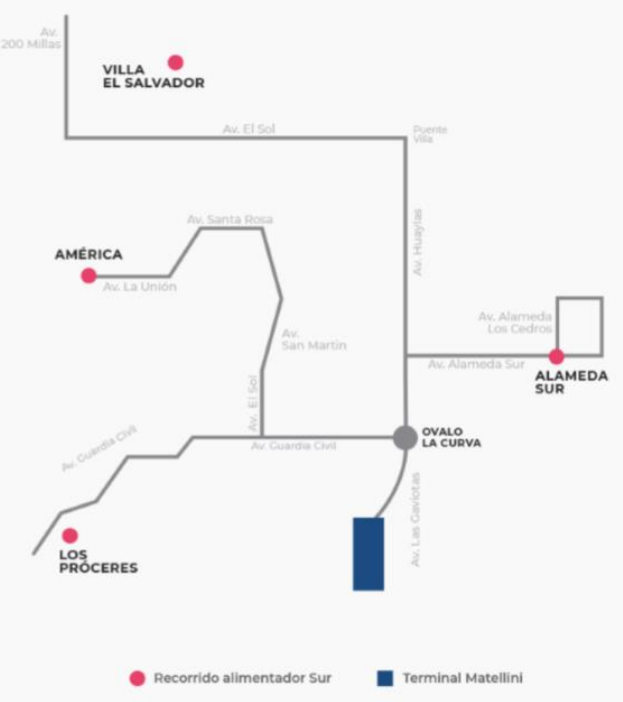

Figura 18: Ruta alimentador Sur - Efectimedia 


\section{DINTELES}

- 02 dinteles laterales

- 02 dinteles laterales

01 dintel frontal
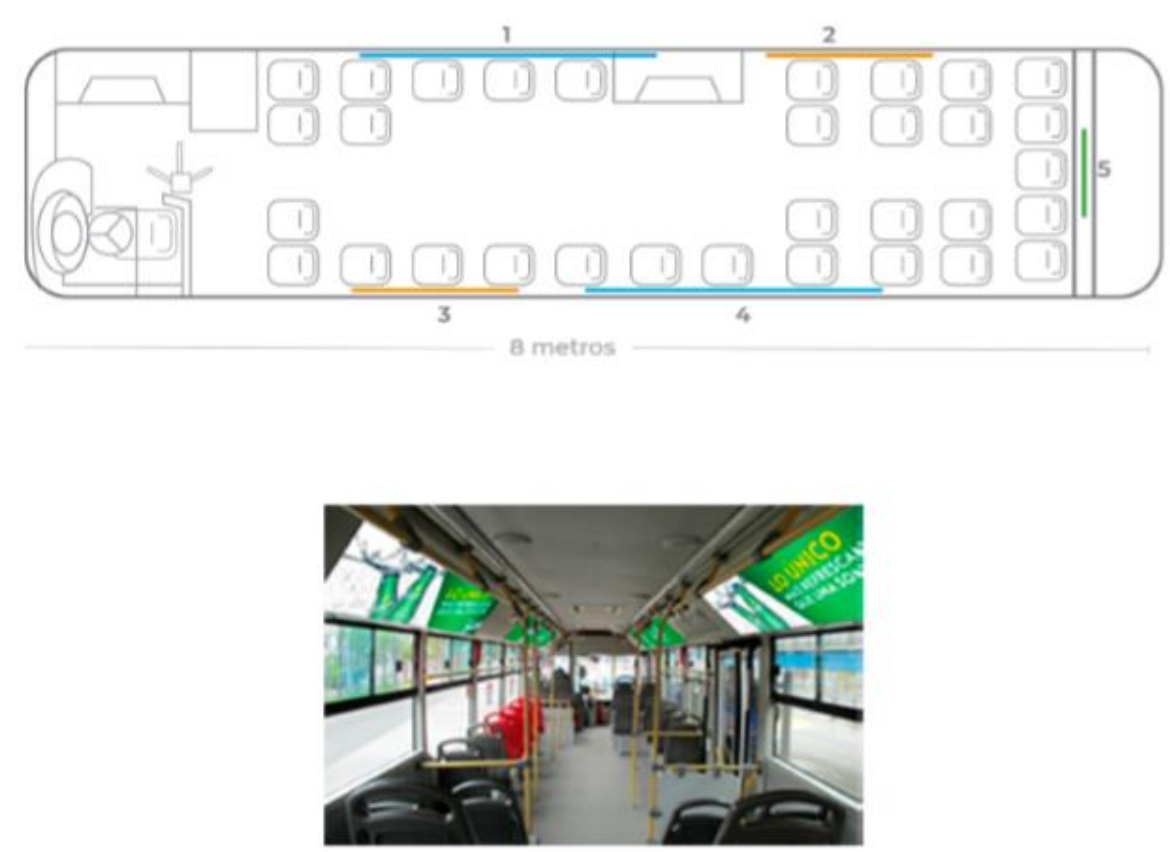

Figura 19: Demo de dindeles alimentador Sur - Efectimedia

Inversión total OOH: S/. 30 226.88 (Treinta Mil Doscientos Veinte Y Seis con 88/100 Soles).

\subsubsection{PR}

Las acciones de relaciones públicas abarcaran la etapa de lanzamiento y los dos primeros meses de la etapa de mantenimiento. Estas tienen como objetivo crear una buena imagen de la marca con los públicos de interés a través de una comunicación adecuada con los aliados estratégicos. Se contará con la participación de Rodolfo Yañez, Ministro de Vivienda, Construcción y Saneamiento, con los embajadores de la marca Gladys Tejeda y Jorge Arcela, y con los deportistas ganadores de los Juegos Panamericanos y Parapanamericanos como Vania Torres, Alexandra Grande, Alonso Wong, Marcela 
Castillo, Kimberly García, Christian Pacheco, Daniella Rosas, Rimas Hilario, Carlos Felipa, entre otros.

\section{Ceremonia de lanzamiento}

Dentro de las acciones de relaciones públicas, se realizará una ceremonia de lanzamiento el viernes 10 de enero de 2020, dentro del complejo de la Villa Panamericana.

Por tratarse de un evento organizado por el Ministerio de Vivienda, Construcción y Saneamiento, los invitados de honor serán el Presidente de la República, el Ministro de Vivienda, Construcción y Saneamiento, y los embajadores de nuestra campaña: Gladys Tejeda y Jorge Arcela. Asimismo, se invitarán a todos los atletas medallistas de los Juegos Panamericanos y Parapanamericanos, así como a los medios de comunicación para la cobertura del evento. Dentro de nuestras estrategias de comunicación estará difundir una nota de prensa sobre este evento de lanzamiento oficial de los departamentos de Villa Panamericana, en la que se dé a conocer el precio de los departamentos y las facilidades de financiamiento a través del Nuevo Crédito Mi Vivienda y Bono Verde. Además, en las siguientes semanas se coordinarán entrevistas con el Ministro de Vivienda, Construcción y Saneamiento para programas dominicales como "Cuarto Poder", "Día D”, "Punto Final" y "Panorama”, y programas de radio en la emisora RPP con el objetivo de difundir sobre el lanzamiento de la venta de los departamentos y los beneficios de financiamiento que está ofreciendo el Ministerio a través del Nuevo Crédito Mivivienda y Bono Verde para que más personas puedan acceder a una vivienda propia.

Durante la etapa de Mantenimiento, se pactarán notas para los programas de televisión como "Domingo al Día", "Día D”, "Reporte Semanal”, "Cuarto Poder", “América Noticias", entre otros noticieros y dominicales, con los embajadores de la campaña: Gladys Tejeda y Jorge Alcedo, con los que se realizará una nota en la Villa Panamericana para que puedan contar cómo es la convivencia con sus compañeros y mostrar cómo son los departamentos resaltando los principales atributos de modernidad, seguridad y accesibilidad. Asimismo, se difundirán notas de prensa con reseñas sobre los testimonios de ambos embajadores acerca de su experiencia en la Villa Panamericana.

En estas dos etapas, con dichas acciones, se estima tener un gran impacto en medios de televisión, escritos y digitales, con los que se logrará un gran alcance.

\section{Inversión total PR: 14,000.00 soles (Catorce Mil con 00/100 Soles)}




\subsubsection{BTL}

Las actividades BTL complementarán las acciones ATL dirigiéndose de forma más cercana al público objetivo.

Se realizará una activación en el Metropolitano, pues como mencionamos, es un medio de transporte de alta afluencia de público que se transporta de Lima Sur a las demás zonas de Lima.

También se irá a ferias inmobiliarias Nexo Inmobiliario, Urbania, ferias en entidades del Estado y en bancos. Estos canales serán altamente efectivos ya que las personas que acuden a pedir información ya tienen un interés en comprar un inmueble.

\section{Activación en el Metropolitano}

Se realizará una activación en la Estación Central del Metropolitano como parte de la etapa de mantenimiento el lunes 02 de marzo.

La duración de la activación será de dos horas (6:30 a 8:30 a.m.)

Esta consistirá en lo siguiente:

- Lentes de realidad virtual para apreciar el interior de los departamentos.

- Persona disfrazada de Milco (mascota de los Juegos Panamericanos) repartiendo USBs en forma de Milco con información sobre la Villa Panamericana grabada y flyers informativos impresos en papel reciclado para reforzar el concepto de cuidado del medio ambiente.

- Banner con información.

- Stand de 0.5 x 1 metro decorado con plantas artificiales.

- El paquete que se contratará con la empresa Efectimedios, encargada de dar los permisos del metropolitano, también incluye una ayudante y un supervisor. 


\section{Ferias inmobiliarias}

Se plantea alquilar stand en dos ferias inmobiliarias: Expo Urbania y Nexo Inmobiliario, ambas ferias se realizan en el Jockey Club, lugar con fácil acceso desde la Avenida Panamericana Sur, por lo que es accesible a nuestro público objetivo. Se alquilará en cada evento un stand de 6 metros cuadrados.

No se seleccionó la feria AdondeVivir, ya que se realiza en San Miguel, distrito muy alejado a la zona de Lima Sur.

La feria Expo Urbania se llevará a cabo en marzo de 2020 y la feria Nexo Inmobiliario, en abril del 2020.

En las ferias se implementarán los siguientes elementos:

- Plantas artificiales en las paredes.

- Letrero en relieve con el logo de la Villa Panamericana.

- 1 panel mostrando las áreas comunes.

- 1 panel con fotos de un departamento amoblado.

- 1 panel con una infografía sobre el Bono Verde.

- 1 panel con una infografía sobre el Nuevo Crédito MiVivienda.

- 2 lentes de realidad virtual para mostrar el interior de los departamentos.

- 1 ruleta con premios de electrodomésticos para los que separan su departamento.

- Electrodomésticos por el valor de 2000 soles.

- 1 carrito de helado para invitar a las personas que se acerquen a pedir información. Tendríamos una alianza con D’onofrio para que el gasto por los helados y el servicio de servirlos sea asumido por dicha empresa. En definitiva, Dónofrio se beneficiaría al tener presencia en las ferias y, nosotros, al atraer visitantes a pedir información.

- 2 asesores de ventas.

- 1 anfitrión disfrazado de Milco.

- 2000 flyers informativos en papel reciclado para reforzar el concepto de cuidado al medio ambiente del Bono Verde. 


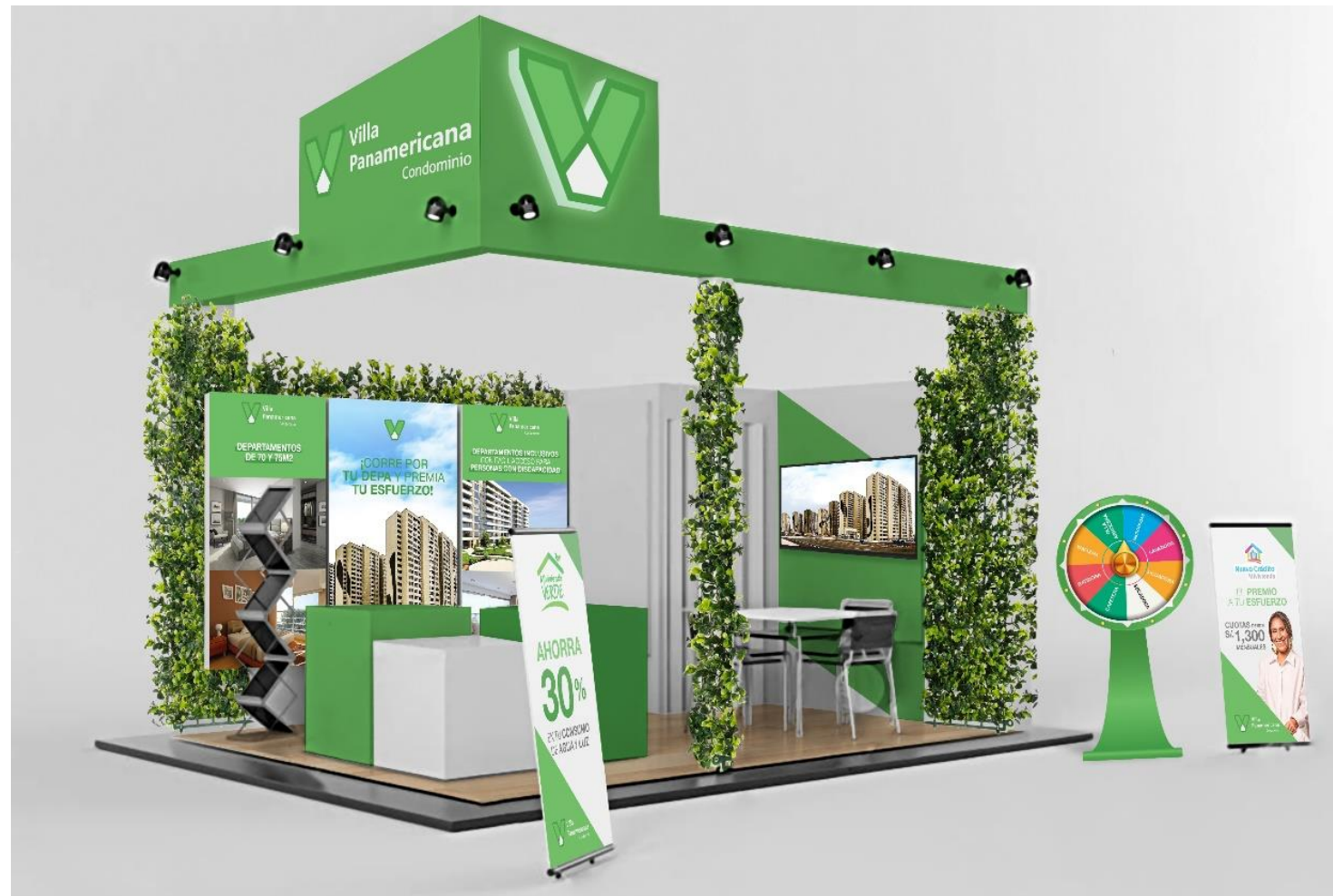

Ilustración 10: Demo de stand en feria - Elaboración propia

\section{Ferias en entidades del Estado}

Al ser nosotros parte del Ministerio de Vivienda, Construcción y Saneamiento, podemos participar de forma gratuita en las ferias que realizan los ministerios para sus colaboradores. La ventaja de estas ferias es que las personas que se acercan a pedir información ya tienen interés en el proyecto, pues los datos de este se envían por la intranet o por correo electrónico antes del evento.

La producción en la feria consistirá con un stand, 2 asesores de ventas, banner informativo, flyers de papel reciclado y USBs en forma de Milco con información del condominio Villa Panamericana grabado.

La lista de los Ministerios en los que se realizará la feria es la siguiente:

1. Ministerio de Agricultura

2. Ministerio de Energía y Minas 
3. Ministerio de Educación

4. Ministerio de Economía y Finanzas

5. Ministerio de Defensa

6. El Ministerio de Comercio Exterior y Turismo

7. El Ministerio del Interior

8. Ministerio de Justicia

9. Ministerio de la Mujer

10. Ministerio de la Presidencia

11. Ministerio de la Producción

12. Ministerio de Relaciones Exteriores

13. Ministerio de Salud

14. Ministerio de Trabajo

15. Ministerio de Transportes y Comunicaciones

16. Ministerio de Vivienda, Construcción y Saneamiento

La fecha de participación en las ferias dependerá de la disponibilidad de cada entidad del Estado.

\section{Ferias en bancos}

Los bancos también realizan pequeñas ferias para promover marcas entre sus colaboradores. Participar en estas ferias no tiene costo y podemos acceder a ellas gracias a las alianzas con estas instituciones financieras, quienes se benefician cuando el comprador de un departamento lo financia por medio de un préstamo bancario. Será una buena vitrina para el condominio Villa Panamericana, ya que, al igual que en las ferias de los ministerios, las personas que piden información ya están interesadas pues se anuncia en la intranet o el correo electrónico detalles sobre las marcas participantes antes del evento.

La producción será similar a la de las ferias en entidades del Estado: un stand, 2 asesores de ventas, banner informativo, flyers de papel reciclado y USBs en forma de Milco con información del condominio Villa Panamericana grabado. 
Los bancos donde se realizarán ferias serán todos los que trabajen con el Nuevo Crédito MiVivienda y Villa Panamericana:

- $\mathrm{BCP}$

- Interbank

- BBVA

- Scotiabank

- Pichincha

- Banco del Comercio

- BanBif

- Banco GNB

La fecha de participación en las ferias dependerá de la disponibilidad de cada entidad financiera.

\section{Alianza con bancos y cajas municipales}

Estas instituciones se verán beneficiadas si una persona decide financiar su vivienda en la Villa Panamericana con ellos. Por lo tanto, se propondrá una alianza que consistirá en trípticos y banners informativos en sus locales de Lima Sur. El Ministerio de Vivienda, Construcción y Saneamiento les facilitará los diseños del banners y trípticos mientras que las instituciones aliadas se harán cargo de la impresión y producción.

Inversión total BTL: 53 965.67 soles (Cincuenta Y Tres Mil Novecientos Sesenta Y Cinco con 67/100 Soles). 


\subsubsection{Digital}

\section{Consumo de redes sociales}

Según el informe de CPI, "Lima Digital 2018” (CPI, 2019), los usuarios de redes sociales en Lima son el $80 \%$ de la población. En el NSE C, el 76.6\% usa redes sociales y en el NSE D, el 75.6\% usa redes sociales. Estas cifras han aumentado en los últimos años gracias a diversos factores como el acceso a la compra de smartphones, las ofertas de operadores móviles que brindan servicios de datos a bajos costos y la necesidad de las personas por encontrar información y entretenimiento de su interés.

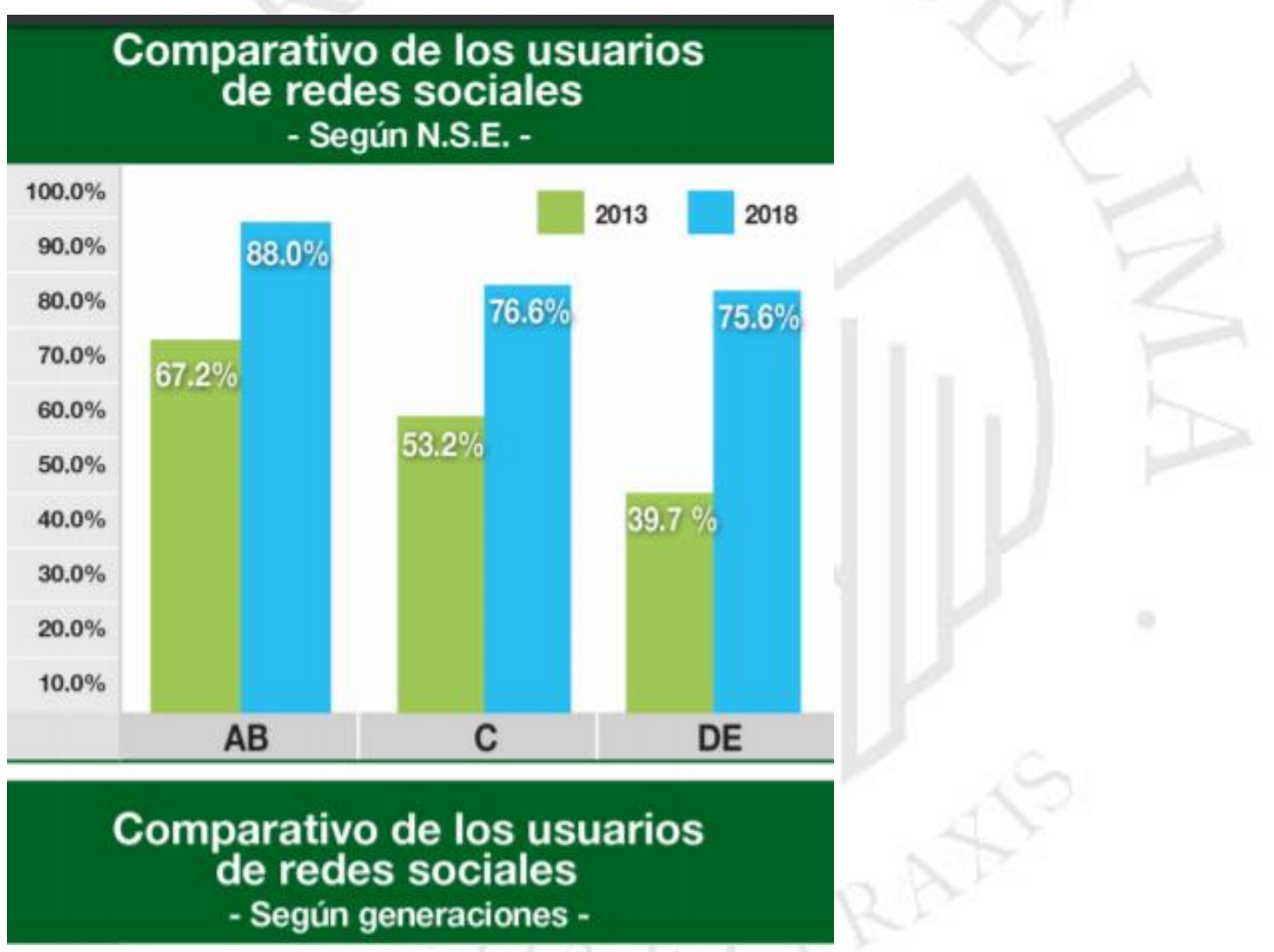

Figura 20: Lima Digital 2018 1- CPI

La generación X (nacidos entre 1961 y 1979) y los Baby Boomers (nacidos entre 1946 y 1964) han aumentado su participación en redes sociales, acortando la distancia con los millenials (nacidos entre 1981 y 1996). 


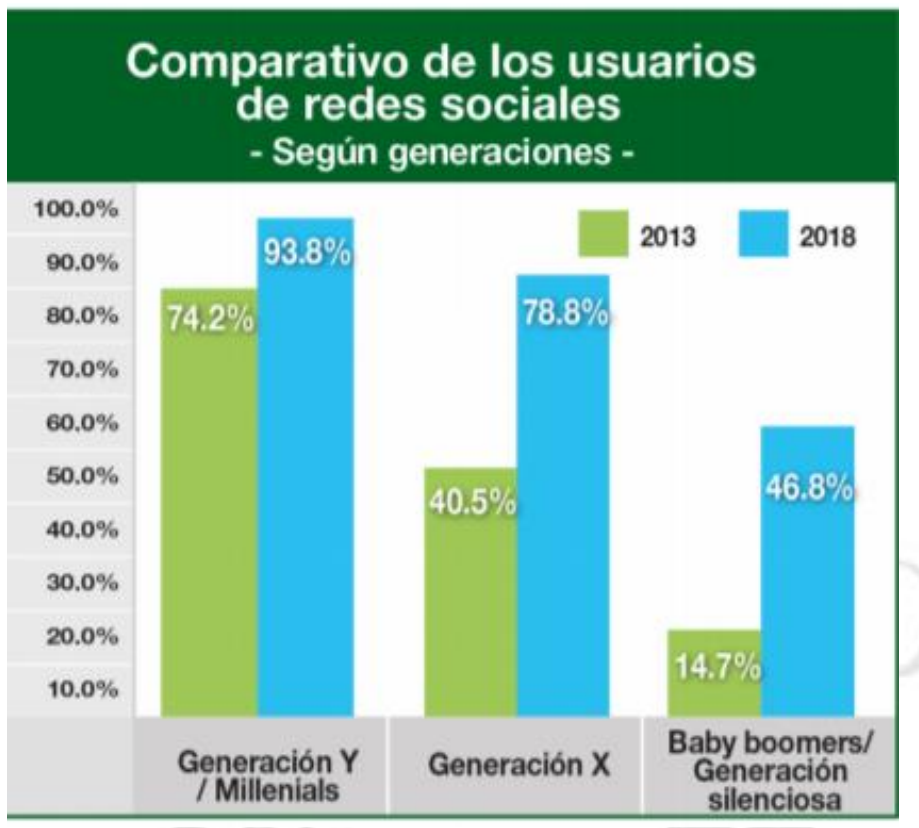

Figura 21: Lima Digital 2018 2- CPI

Las redes sociales más utilizadas por los limeños son Facebook (72.7\%) y Whatsapp $(68.6 \%)$. En menor medida se utiliza Instagram (25\%) y Twitter (12.7\%), entre otros.

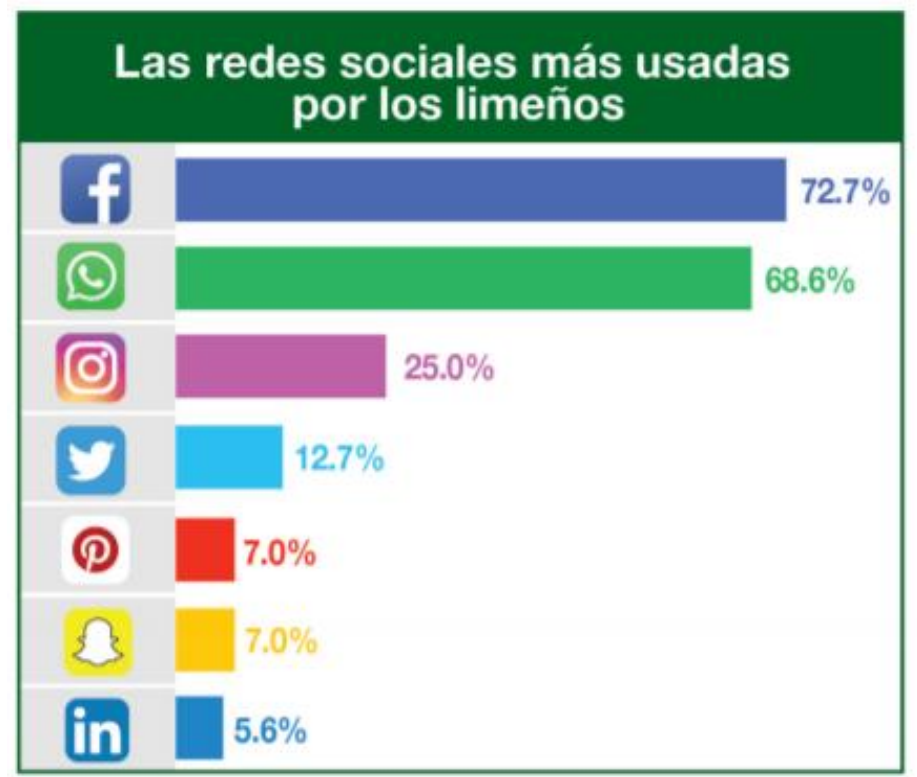

Figura 22: Lima Digital 20183 - CPI 


\section{Facebook}

La red social utilizada para esta campaña será Facebook, por tratarse de la red social más utilizada por los limeños según el informe "Lima Digital 2018” (CPI, 2019). Para administrar la red social y hacer los diseños de las publicaciones se contratará a un Community Manager por los 6 meses de la campaña. La grabación, producción y edición de videos, así como la sesión de fotos será realizado por una productora.

Las fotografías que se usarán serán de sesiones que aplicarán tanto para Facebook, página web, materiales ATL y BTL.

Según Inmobiliaria Marketing (2019), una de las claves para una exitosa campaña de marketing digital para inmobiliarias es el Marketing de Contenido.

Sin dejar de brindar información sobre los beneficios de la Villa Panamericana y las facilidades de financiamiento, también se brindará por Facebook una serie de videos, infografías e imágenes con contenido de utilidad para los internautas y posibles clientes.

El uso de Facebook es importante para la campaña, ya que está comprobado que este medio atrae potenciales clientes a la sala de ventas. Se debe mantener este medio constantemente actualizado para brindar una seria imagen de marca que brinda información de relevancia a los potenciales clientes. (Del Valle, Guillén, Muroya y Quino, 2017)

Segmentación

Sexo: Todos

Edad: 25 a 45 años

Lugares: Se seleccionó con el marcador geográfico la Villa Panamericana y $10 \mathrm{~km}$ a la redonda. 
(-12.2039, -76.9576) + 10km

\section{Agrega lugares}

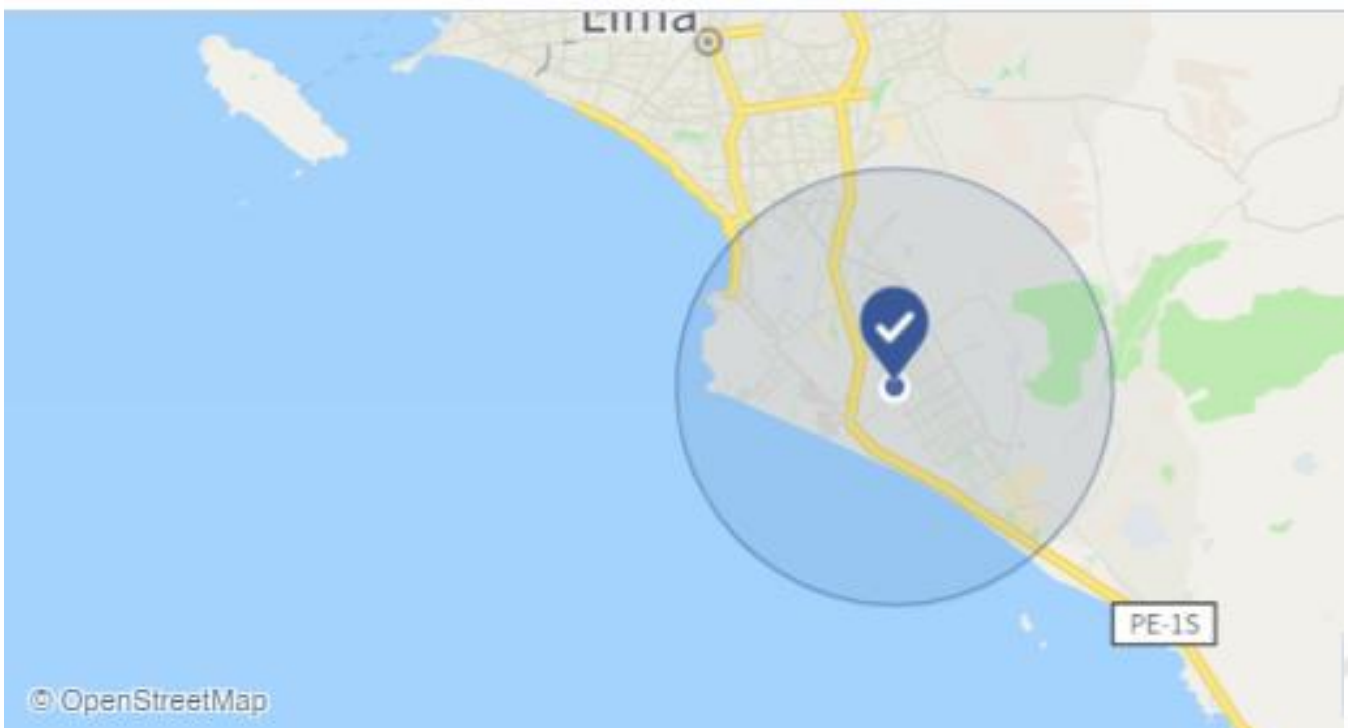

Figura 23: Segmentación por zona - Facebook

Intereses (Incluir personas que coinciden con):

- Agentes inmobiliarios.

- Apartamentos.

- Inversiones inmobiliarias.

- Propiedades.

- Vivienda.

- Espíritu empresarial: Este término se seleccionó ya que, según el Perfil del Jefe del Hogar Peruano, el 68\% de jefes del hogar se considera emprendedor (Ipsos, 2018).

El tamaño del público potencial: 380000 personas.

En pauta se invertirá 30000 soles por los 6 meses. La mitad en los dos meses de lanzamiento, etapa en la que el objetivo será el awareness. La segunda mitad del presupuesto se destinará a la etapa de mantenimiento y tendrá el objetivo de engagement 
Con esta inversión se podrá lograr un alcance de entre 21.000 y 62.000 personas al día en la etapa de lanzamiento y entre 12.000 y 35.000 personas al día en la etapa de mantenimiento.

\section{Frecuencia de publicaciones}

Según Rockcontent, los días con más tráfico en Facebook son los miércoles y jueves, seguido por los martes en los horarios desde las 10 a.m. hasta las 3 p.m. Por lo tanto, se publicará tres veces a la semana en esos días y en ese rango de horario.

\section{Facebook Global Engagement}

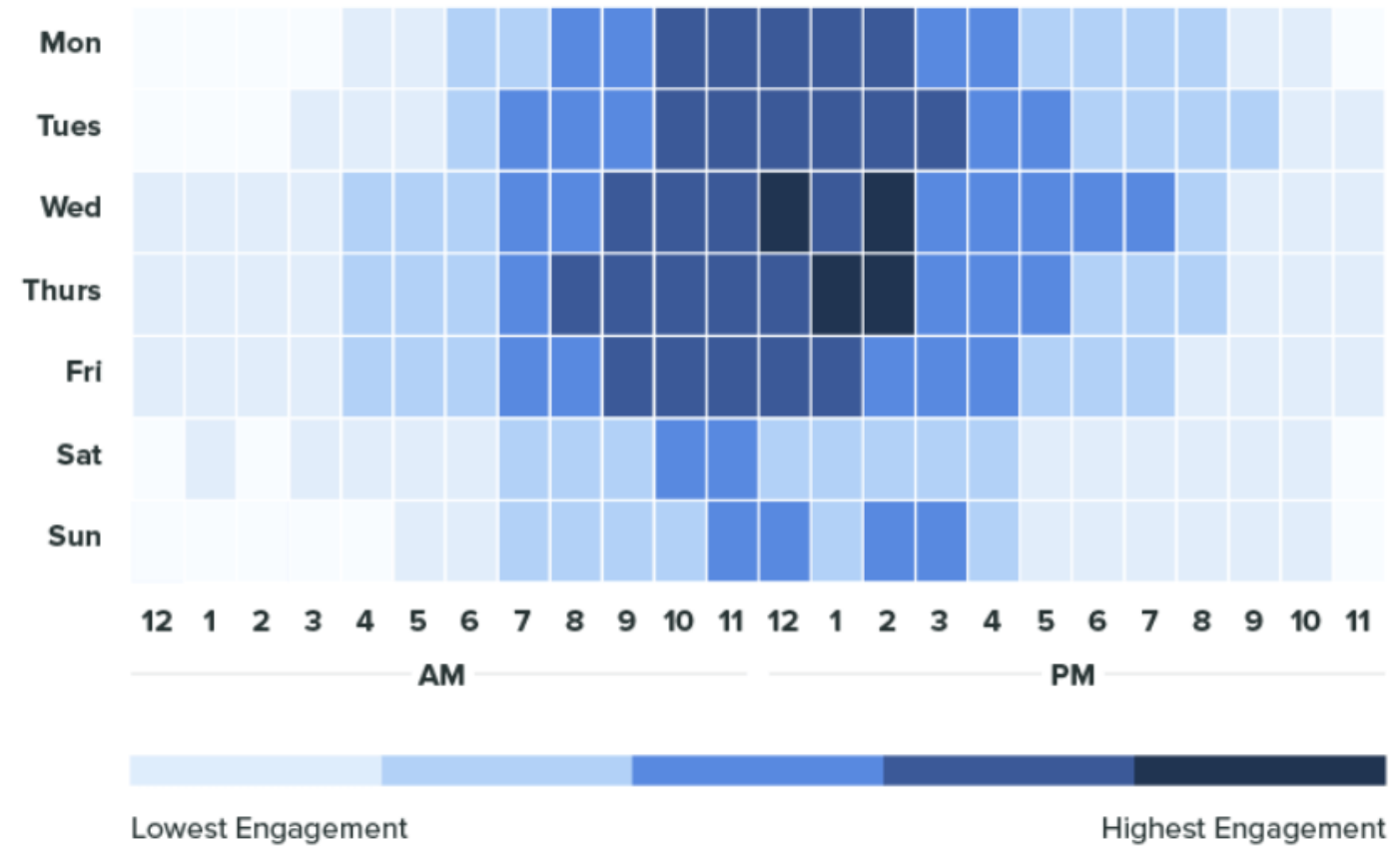

Figura 24: Mapa de temperatura Facebook Global Engagement - Rockcontent

- $\quad$ Page Video Ads

Según Social Bakers, el alcance orgánico de videos supera al de otros tipos de publicaciones en Facebook. (Social Bakers, 2015). 


\section{Average Organic Reach}

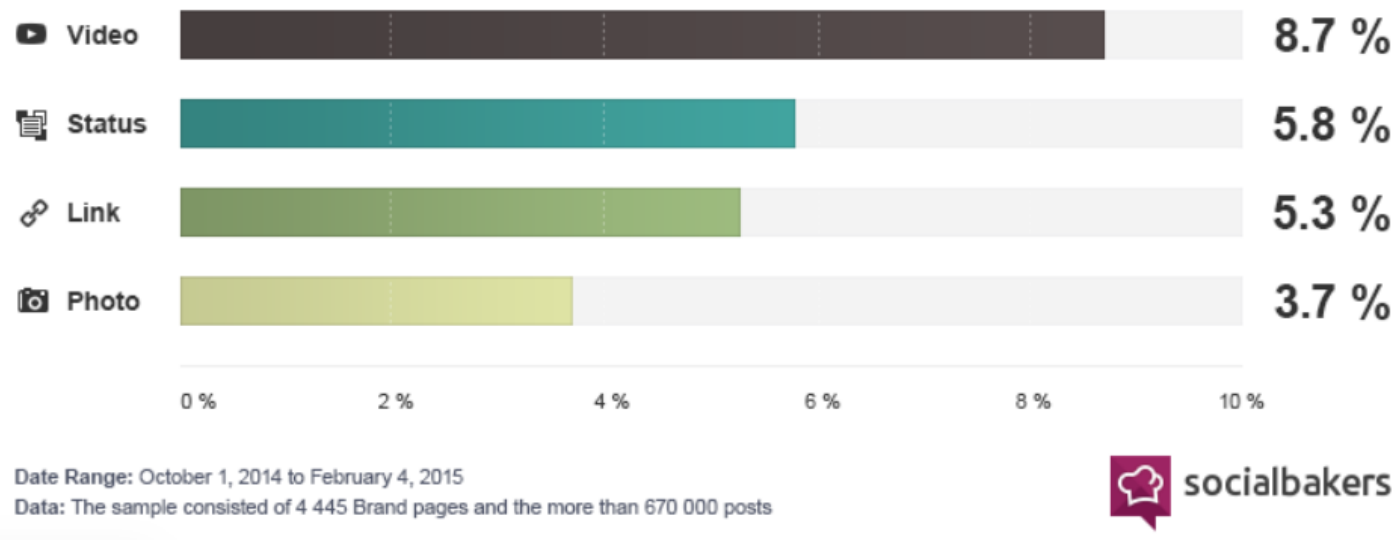

Figura 25: Avarege Organic Reach - Social Bakers

Videos de Lanzamiento

- Video 1: Video de 50 segundos que presente a Gladys Tejeda mostrando los atractivos de vivir en la Villa Panamericana y el precio especial por lanzamiento.

- Video 2: Video de 1 minuto mostrando a Jorge Arcela (Ganador de Tiro: Mix. 10m Rifle de Aire Tendido) mostrando las características de su departamento en la Villa Panamericana, construido con facilidades para personas discapacitadas. Se eligió a este atleta ya que se moviliza en silla de ruedas, lo que permitirá mostrar las facilidades que le ofrece el departamento para desplazarse.

- Video 3: Video de 30 segundos presentado por Gladys Tejeda donde explica por qué vivir en un condominio cerrado como la Villa de Atletas le da tranquilidad y seguridad frente a vivir en una casa con puerta a la calle.

- Video 4: Video de 10 segundos presentando a los vigilantes de la Villa Panamericana diciendo la frase "Quédate tranquilo en la Villa".

- Video 5: Video de 20 segundos con animaciones y voz en off explicando las facilidades de pago con el Nuevo Crédito MiVivienda.

- Video 6: Video de 30 segundos mostrando tomas de las instalaciones de la Villa Panamericana explicando cómo se ahorra energía, agua y cómo se 
tratan las aguas residuales. Factores que permiten ahorrar en los pagos mensuales del hogar y además ahorrar $4 \%$ del valor de la vivienda.

- Video 7: Video de 20 segundos con animaciones y voz en off explicando el beneficio financiero con el Bono Verde.

- Video 8: Video de 10 segundos con voz en off mostrando tomas de las áreas comunes y áreas verdes de la Villa Panamericana.

- Video 9: Video de 10 segundos con voz en off mostrando tomas del exterior de la Villa Panamericana, las avenidas aledañas y los lugares de interés en los alrededores (Como Makro, Mega Plaza, SiSol, bancos, farmacias y restaurantes).

Videos de mantenimiento:

- Video 10: Video de 1 minuto con entrevista a Javier Salazar, gerente general de la inmobiliario Besco (empresa encargada de construir la Villa Panamericana) donde explica por qué la construcción es segura y con garantía.

- Video 11: Video de 10 segundos en cámara rápida mostrando un travelling por todo un departamento amueblado de 70 metros cuadrados.

- Video 12: Video de 15 segundos en cámara rápida mostrando un travelling por todo un departamento inclusivo, amueblado acondicionado para personas con discapacidad.

- Video 13: Video de 15 segundos con animación y voz en off simulando el financiamiento de un departamento de 70 metros cuadrados con un banco, ya que los bancos ofrecen menores tasas de interés que las cajas financieras (Gestión, 2019).

- Video 15: Video de 20 segundos donde se muestre a los deportistas Vania Torres, Alexandra Grande, Alonso Wong, Marcela Castillo, Kimberly García, Christian Pacheco, Daniella Rosas, Rimas Hilario, Carlos Felipa y Jorge Arcela haciendo uso de las áreas comunes.

- Video 16: Video de 15 segundos con tips para ahorrar espacio en tu departamento.

- Video 17: Video de 15 segundos con tips para decorar tu departamento con objetos reciclados. 
- Video 18: Video de 15 segundos con tips para ahorrar energía.

- Video 18: Video de 15 segundos con tips para ahorrar agua.

- Video 19: Video de 15 segundos con tips para cuidar tus plantas dentro de tu departamento.

\section{- $\quad \underline{\text { Photo Ads }}$}

Las imágenes reforzarán los mensajes transmitidos en los videos.

Photo Ads Lanzamiento:

- Photo Ad 1: Fotografía de Gladys Tejeda partiendo en una carrera con el texto "Arrancaron las ventas".

- Photo Ad 2: Secuencia de imágenes mostrando el interior de un departamento de 70 metros cuadrados.

- Photo Ad 3: Secuencia de imágenes mostrando el interior de un departamento con facilidades para discapacitados.

- Photo Ad 4: Secuencia de imágenes mostrando áreas verdes.

- Photo Ad 5: Secuencia de imágenes mostrando sala de usos múltiples.

- Photo Ad 6: Secuencia de imágenes mostrando juegos para niños.

- Photo Ad 7: Secuencia de fotografías de Jorge Arcela dentro de su departamento mostrando las facilidades para personas con discapacidad.

- Photo Ad 8: Secuencia de fotos de la vista desde un departamento en el piso 20 .

- Photo Ad 9: Infografía sobre las condiciones y beneficios de adquirir el departamento en la Villa Panamericana con el Nuevo Crédito MiVivienda.

- Photo Ad 10: Infografía explicando el Bono MiVivienda Verde.

- Photo Ad 11: Fotografía de un vigilante de la Villa Panamericana con la frase "Quédate tranquilo en la Villa".

Photo Ads Mantenimiento:

- Photo Ad 12: Imagen con las cuotas mensuales a pagar por departamento 
- Imagen en alianza con Makro, mostrando la fachada de Makro en Villa el Salvador con el texto "A un paso de la Villa Panamericana”.

- Photo Ad 13: Imagen en alianza con Mega Plaza Villa el Salvador II, mostrando su fachada con el texto "A un paso de la Villa Panamericana".

- Photo Ad 14: Imagen en alianza con Universidad Tecnológica del Perú mostrando su fachada y el texto "A un paso de la Villa Panamericana".

- Photo Ad 15: Imagen en alianza con Universidad Autónoma del Perú mostrando su fachada con el texto "A un paso de la Villa Panamericana".

- Photo Ad 16: Imagen en alianza con Sisol, mostrando su fachada con el texto "A un paso de la Villa Panamericana".

- Photo Ad 17: Imagen en alianza con Mass, mostrando su fachada con el texto "A un paso de la Villa Panamericana”.

- Photo Ad 18 al 27: 9 fotografías de deportistas Vania Torres, Alexandra Grande, Alonso Wong, Marcela Castillo, Kimberly García, Christian Pacheco, Daniella Rosas, Rimas Hilario, Carlos Felipa y Jorge Arcela en los distintos ambientes interiores y exteriores de la Villa Panamericana con frases:

- “Villa Panamericana: El premio a tu esfuerzo.

- “Corre por tu depa."

- "Un lugar tranquilo y seguro para tu familia."

- "La mejor vista panorámica de Villa el Salvador."

- "Con el Fondo MiVivienda es más fácil tener tu depa en la Villa Panamericana."

- "Ahorra hasta 30\% en tus tarifas mensuales de luz y agua con la tecnología eco amigable de la Villa Panamericana."

- "Un lugar para disfrutar."

- "El condominio con más áreas verdes."

- "Comodidad y modernidad en el corazón de Lima Sur."

- Photo Ad 28: Infografía con los logos de los bancos y financieras con las que se puede financiar un departamento en la Villa Panamericana.

- Photo Ad 29: Infografía sobre programa de integración para la buena convivencia en el condominio.

- Photo Ad 30 al 36: Infografías con consejos:

- Consejo para cuidar agua 
- Consejo para ahorrar energía

- Consejo para reciclar botellas

- Consejo para ahorrar espacio

- Consejo para iluminar mejor tus ambientes

- Consejo para tener plantas en casa

- Consejo para organizar tu cocina

- Photo Ad 37 al 64: Invitación a activación en Metropolitano, feria Urbania, feria Nexo Inmbiliario, 8 ferias en bancos y 17 ferias en entidades del Estado.

- Photo Ad 65 a 93: Álbumes de la activación en Metropolitano, feria Urbania, feria Nexo Inmbiliario, 8 ferias en bancos y 17 ferias en entidades del Estado.

\section{- Links y Canvas}

Se compartirán los links y canvas del siguiente material:

- Link a 15 notas de las notas de prensa en los diferentes medios de comunicación.

- Tour virtual en página web propia: Departamento $70 \mathrm{~m} 2$

- Tour virtual en página web propia: Departamento 75 m2

- Tour virtual en página web propia: Área de parrillas.

- Tour virtual en página web propia: Área de juegos para niños.

- Tour virtual en página web propia: Sala de usos múltiples.

- Página web propia: Página explicativa de MiVivienda y Bono Verde.

- Página web propia: Simulador de financiamiento (Formulario dinámico).

\section{- $\quad$ Alianzas en Facebook}

Para aumentar el alcance de las publicaciones, se formarán alianzas con marcas que se beneficiarán con la mudanza de un gran número de familias a la Villa Panamericana por tener locales en la zona. Estas marcas compartirán algunas de las publicaciones del Facebook de Villa Panamericana en sus perfiles. 
Las marcas seleccionadas para realizar alianzas son:

- Makro - 557.146 seguidores

- Mega Plaza - 1.735.197 seguidores

- Universidad Tecnológica del Perú - 186.023 seguidores

- Universidad Autónoma del Perú - 152.384 seguidores

- $\quad$ SiSol - 39.524 seguidores

- Mass - 1.776 seguidores

También se formarán alianzas con los bancos y cajas municipales que se beneficiarán con la Villa Panamericana al dar los créditos a las familias que adquieran un departamento. Estas marcas también replicarían en sus plataformas algunas publicaciones del Facebook de la Villa Panamericana en sus perfiles, así como crear publicaciones propias promoviendo los beneficios de vivir en este condominio. La cantidad de seguidores de cada entidad financiera es la siguiente:

- $\quad$ BCP - 1.540.801 seguidores

- Interbank - 1.975.731 seguidores

- BBVA - 5.518.029 seguidores

- Scotiabank - 972.078 seguidores

- Pichincha - 109.621 seguidores

- Banco del Comercio - 79.593 seguidores

- BanBif - 297.323 seguidores

- Banco GNB - 42.114 seguidores

- CMAC Sullana - 48.503 seguidores

- CMAC Ica - 22.961 seguidores

- CMAC Tacna - 20.626 seguidores

- CMAC Maynas - 15.251 seguidores

- CMAC Huancayo - 63.641 seguidores

- CMAC Cusco - 313.861 seguidores

- CRAC Raíz - 15.130 seguidores

- Edpyme Mi Casita Hipotecaria - 1.920 seguidores

- Financiera TFC - 26.032 seguidores

- Financiera Efectiva - 44.566 seguidores 
Por otro lado, el Ministerio de Vivienda tiene una página de Facebook (286.733 seguidores) donde también compartirán el contenido publicado en el perfil de Villa Panamericana.

Por último, nuestros embajadores de marca Gladys Tejeda (150.242 seguidores) y Jorge Alceda (811 seguidores) también compartirán las publicaciones donde salgan ellos, lo cual los beneficia al generar más contenido para sus seguidores.

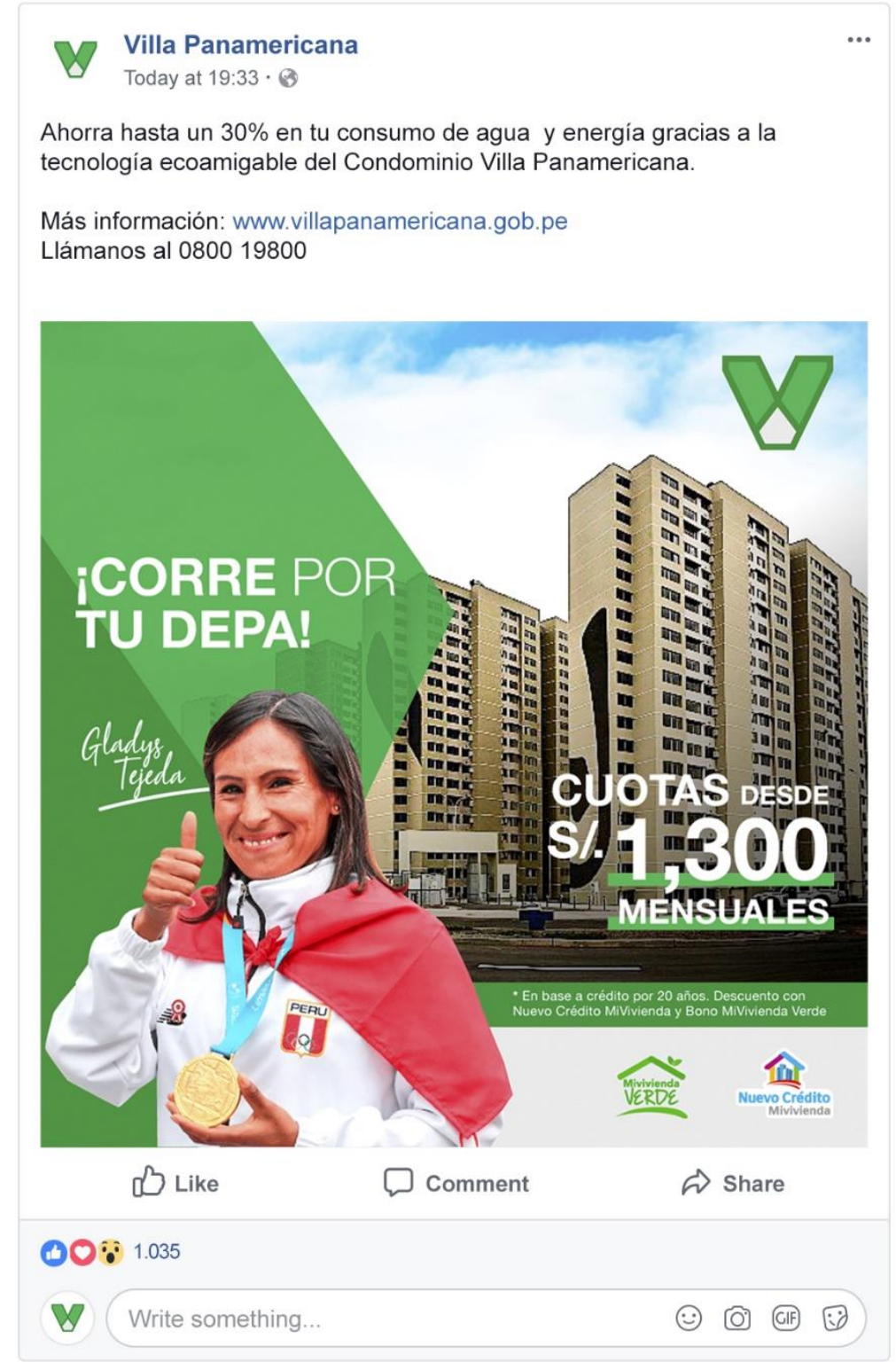

Ilustración 11: Ejemplo 1 publicación en Facebook - Elaboración propia 


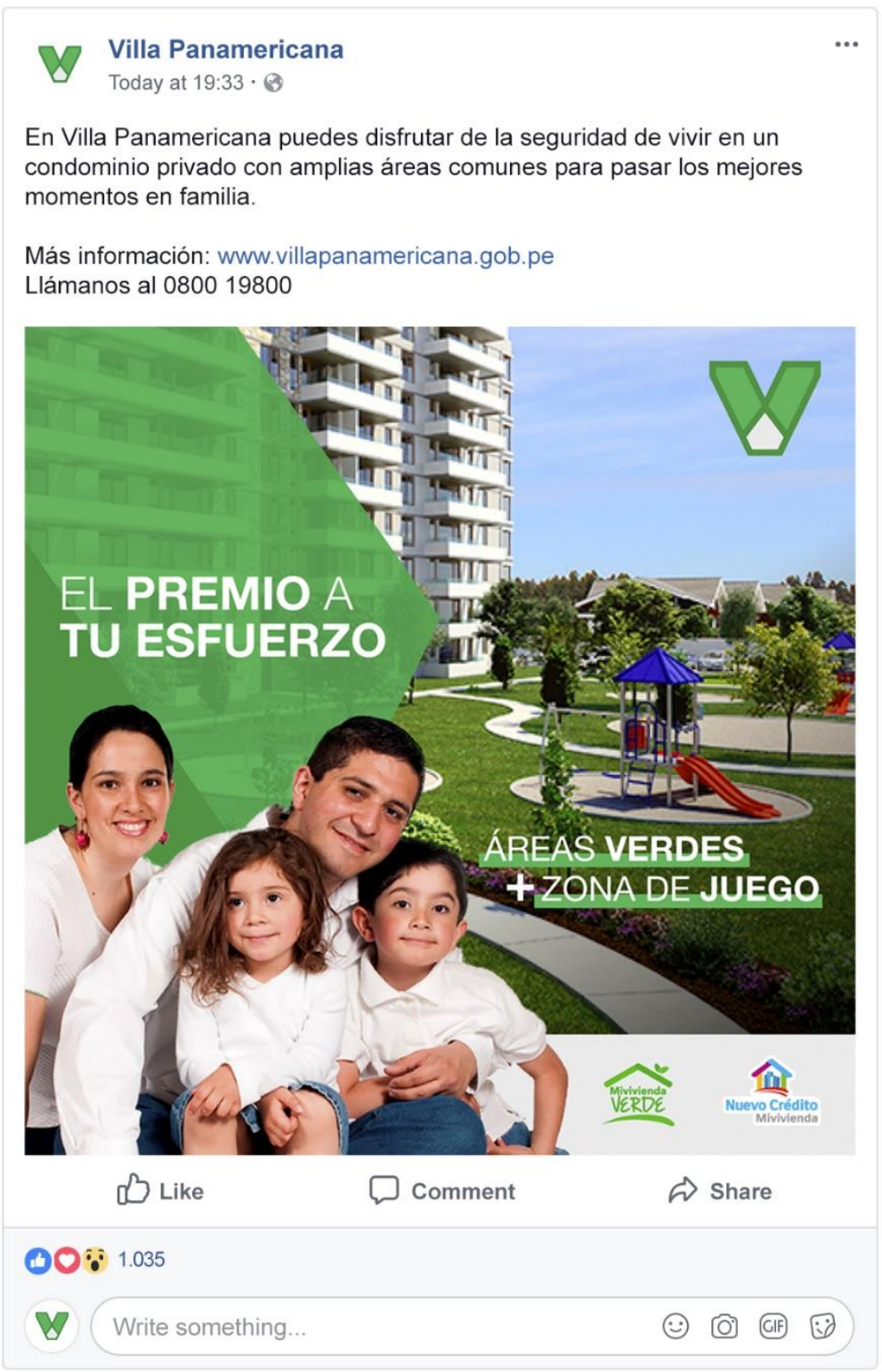

Ilustración 12: Ejemplo 2 publicación en Facebook - Elaboración propia

\section{Alianza Mailing}

Como parte de la alianza con bancos y financieras, cada institución mandará una campaña de mailing a sus clientes promocionando las ventajas de la Villa Panamericana. Ellos se benefician al brindar los préstamos a las personas interesadas en comprar un departamento.

Página Web, landing page y Google Ads. 
Se construirá una página web informativa mostrando las características del proyecto, así como un landing page para dirigir desde Google Ads.

Según Inmobiliaria Marketing (2017), "El medio que mejores resultados obtiene a corto plazo es Google Adwords." Por ello es importante que la Landing Page, el anuncio en Google Ads y la Página Web contenga información útil y de alto impacto.

\section{Página Web}

El dominio será villapanamericana.gob.pe, el cual será adquirido en el portal Punto.pe, administrado por la Red Científica Peruana.

Para el hosting se contratará a Go Daddy, ya que en nuestro análisis ha sido identificada como la empresa con mejor servicio postventa y soporte técnico entre proveedores peruanos.

Se seleccionará el plan "Máximo Hosting" ya que tiene ancho de banda sin medición, lo cual permitirá que la web sea rápida. Además, soporta videos y fotografías de alta resolución.

Para la construcción de la página web se contratará a la agencia Power Brand. La web será responsive y se trabajará los textos con Yoast SEO para garantizar que tenga el mejor posicionamiento orgánico posible. Contará con la siguiente arquitectura:

- Home

- Tour virtual

- Departamento $70 \mathrm{~m} 2$

- Departamento $75 \mathrm{~m} 2$

- Área de parrillas

- Área de niños

- Sala de usos múltiples

- MiVivienda y Bono Verde (Página explicativa)

- Simulador de financiamiento (Formulario dinámico)

- Planos de departamentos

- Galería

- Contáctanos (Mapa y formulario de contacto) 
Si bien la página web será responsive, mostraremos contenidos diferenciados para Web y para Móvil.

Según Inmobiliaria Marketing (Inmobiliaria Marketing, s.f.), cuando se trata de compras pequeñas e impulsivas, la campaña en dispositivos móviles es crucial. Por otro lado, cuando se trata de una compra grande como es la compra de un inmueble, los usuarios buscan información desde su computadora. Si es que buscan por su celular es mejor dirigirlos a un número de teléfono.

Es por ello que el primer mensaje de la versión móvil será el número de teléfono con el cual comunicarse para tener más información.

\section{Landing page e E-book}

Uno de los errores más frecuentes en el Marketing Digital de inmobiliarias es que el anuncio de Google Ads se dirige a la Página Web principal y no a un Landing Page o Página de aterrizaje (Inmobiliaria Marketing, s.f.). Se debe apuntar a que los cibernautas dejen sus datos dándoles contenido de valor como un E-Book.

La Landing Page consistirá en un formulario de registro y un enlace a la Página Web. Al llenar tus datos en el formulario recibes información sobre la Villa Panamericana y un enlace de descarga para un E-Book titulado "La forma más inteligente de financiar tu departamento". La descarga de este material será el Call to Action central ya que "Solicitar en la misma página múltiples opciones confundirá a los usuarios y reducirá enormemente las tasas de conversión.” (Inmobiliaria Marketing , s.f.)

Este E-Book consistirá en información sobre el Nuevo Crédito MiVivienda, el Bono MiVivienda Verde, consejos para administrar tus recursos económicos para ahorrar en el pago inicial y cumplir con las cuotas de la hipoteca.

$\underline{\text { Google Ads }}$ 
Es importante para redactar un buen anuncio en Google Ads identificar una necesidad clara y mostrar cómo aportar una solución. (Inmobiliaria Marketing, s.f.).

Se lanzarán anuncios que dirigen a la Landing Page. El contenido será el siguiente:

- Necesidad: ¿Buscando tu nuevo hogar?

- Solución: Modernidad y Seguridad en la Villa Panamericana

- Call to Action: ¡Corre por tu depa y premia tu esfuerzo!

Para tener el mayor nivel de conversiones y ahorrar presupuesto se pueden utilizar palabras menos competitivas y así optimizar la campaña. (Inmobiliaria Marketing, s.f.) Para la campaña de SEM en Google se invertirá 400 soles mensuales en 5 palabras clave:

\section{Palabras clave}

\begin{tabular}{|c|c|c|c|}
\hline & Coste & Clics & Impresiones $\mathbf{\nabla}$ \\
\hline $\begin{array}{l}\text { departamentos villa el } \\
\text { salvador }\end{array}$ & 252,57 PEN & 277 & 2.668 \\
\hline bono mivivienda verde & 116,73 PEN & 73 & 635 \\
\hline villa panamericana & 28,55 PEN & 16 & 318 \\
\hline nuevo crédito mivivienda & 2,59 PEN & 3 & 17 \\
\hline $\begin{array}{l}\text { departamentos villa } \\
\text { panamericana }\end{array}$ & 0,00 PEN & 0 & 0 \\
\hline
\end{tabular}

Tabla 9: Presupuesto por palabra clave - Google Keyword Planner

En el siguiente gráfico se muestran las previsiones de métricas mensuales estableciendo un Costo por Clic máximo de 5 soles:

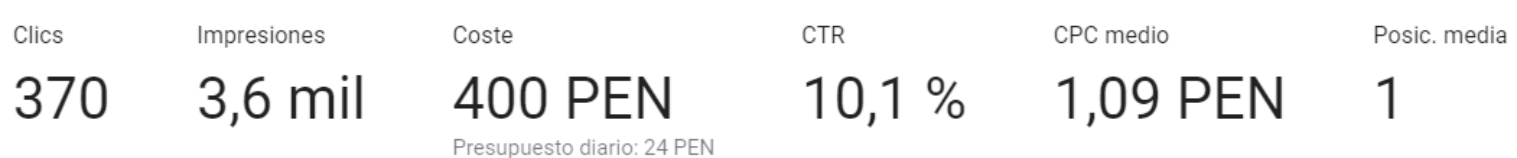


Con esta inversión se logrará una posición media de 1, es decir, se estará en el primer puesto de la búsqueda pagada en el buscador de Google y nos dará un total de 370 clics mensuales.

\section{Portales inmobiliarios}

Se publicará anuncios en los tres portales inmobiliarios pagados que funcionan actualmente en Lima: Urbania, AdondeVivir y Nexo Inmobiliario.

\section{Urbania:}

En Urbania se contratará tres paquetes de aviso Premium por tres periodos de 60 días. Uno de los avisos mostrará los departamentos de 70 metros cuadrados y el segundo mostrará los departamentos acondicionados para discapacitados.

Se eligió este paquete ya que ofrece mayor exposición, posición superior en resultados, hasta 200 fotos del inmueble y un video donde se podrá presentar el exterior, interior y áreas comunes del condominio.

Además, este paquete incluye publicación en la versión impresa de Urbania en el diario El Comercio un día sábado y un día domingo, y en el diario El Trome un día domingo.

\section{AdondeVivir:}

AdondeVivir cuenta con más de 1.6 millones de visitas por mes (AdondeVivir, s.f.). Se seleccionará el paquete "Aviso Destacado" ya que tiene más visibilidad y tiene la duración de 3 meses.

Se realizarán 2 anuncios por 6 meses al igual que en Urbania.

\section{Nexo Inmobiliario:}


Nexo Inmobiliario es el portal inmobiliario de la Asociación de Empresas Inmobiliarias del Perú (ASEI).

Se pagará la suscripción mensual de 1500 soles mensuales, anunciando los dos tipos de departamentos disponibles durante los 6 meses de la campaña.

Inversión total en Digital: S/. 60 089.94 (Sesenta Mil Ochenta Y Nueve con 94/100 Soles) 


\section{RESUMEN DE INVERSIÓN DE PRESUPUESTO}

En el siguiente link se podrá encontrar el desglose del presupuesto:

https://drive.google.com/file/d/1OYFNzv0Q3qbRepJ1xvE6hJ3q2JLwPmQc/view

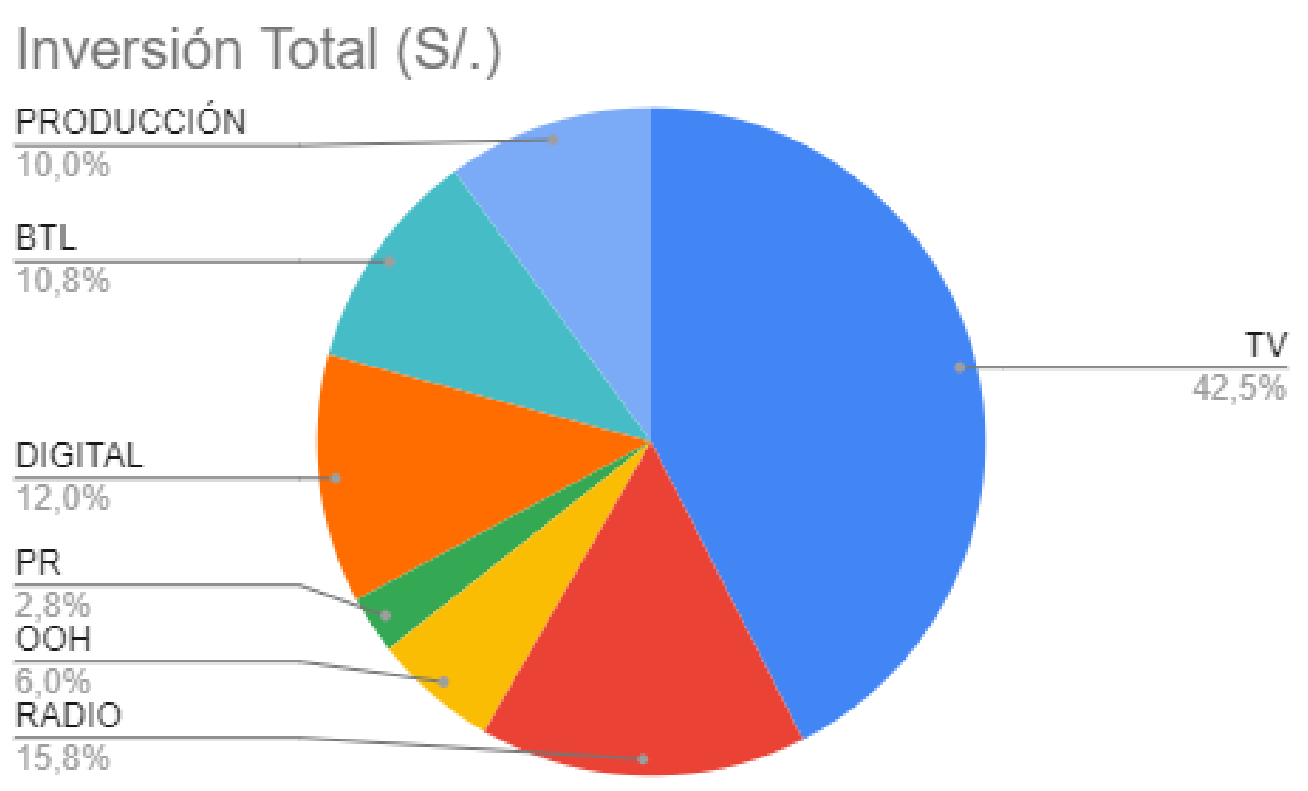

Figura 26: Distribución de presupuesto publicitario - Elaboración propia

\begin{tabular}{|l|r|}
\hline Presupuesto Total & Inversión Total (S/.) \\
\hline TV & $212.278,41$ \\
\hline RADIO & $79.060,00$ \\
\hline OOH & $30.226,88$ \\
\hline PR & $14.000,00$ \\
\hline DIGITAL & $60.089,94$ \\
\hline BTL & $53.965,67$ \\
\hline PRODUCCIÓN & $50.000,00$ \\
\hline TOTAL & $\mathbf{4 9 9 . 6 2 0 , 9 0}$ \\
\hline
\end{tabular}

Tabla 11: Distribución de presupuesto publicitario - Elaboración propia 


\section{CONCLUSIONES Y RECOMENDACIONES}

- Para este proyecto es necesario transmitir los siguientes mensajes clave: Ahorro y financiamiento, seguridad, modernidad y accesibilidad.

- No se debe romper el vínculo del condominio con el legado de los Juegos Panamericanos, ya que la prensa ha cubierto detalles del proyecto desde su construcción, por lo que se puede seguir haciendo notas como un tema de interés público, esto sería publicidad gratuita.

- Es importante mantener alianzas estratégicas con bancos, cajas municipales, ministerios, comercios y universidades cercanas a la Villa Panamericana para aumentar el alcance de la información sobre el condominio.

- Los asesores de venta son un elemento clave para la campaña en ferias. Es importante que estén bien capacitados y que conozcan todos los argumentos de venta.

- Se debe reforzar el atributo de seguridad contratando una empresa que administre el condominio y que se encargue de coordinar la contratación y pagos al personal de seguridad, considerando que es uno de los factores decisivos para nuestro público objetivo al momento de elegir una vivienda.

- La administración del condominio debe coordinar la organización de eventos de convivencia para garantizar la generación de comunidad entre las familias que viven en la Villa Panamericana.

- Se recomienda mantener el vínculo con los medallistas que ganaron los departamentos en la Villa bajo el concepto de la campaña "El premio a tu esfuerzo", ya que es una oportunidad para tener más alcance a las audiencias que los siguen a ellos para difundir la venta de los departamentos. 


\section{REFERENCIAS}

1. AdondeVivir. (s.f.). Publica tu inmueble ahora. Recuperado 14 septiembre, 2019, de https://www.adondevivir.com/publica-tu-propiedad

2. CPI. (2018). AUDIENCIAS RADIALES. Recuperado de https://www.cpi.pe/images/upload/paginaweb/archivo/26/mr_resumen_anual_radial_20 1903.pdf

3. CPI. (2019). Lima Digital. Recuperado de http://cpi.pe/images/upload/paginaweb/archivo/26/MR_Limadigital2018.pdf

4. CPI. (2019). Perú: Población 2019. Recuperado de http://cpi.pe/images/upload/paginaweb/archivo/26/mr_poblacional_peru_201905.pdf

5. Del Valle Roeder, Maria Fe; Guillén Huamancaja, Luis Rafael; Muroya Lei, Melanie; Quino Sullca, S. L. (2017). Análisis del impacto de Facebook como parte de una estrategia de marketing digital para aumentar las ventas de una empresa inmobiliaria en el perú, en el siglo XXI. Universidad Peruana de Ciencias Aplicadas (UPC).Recuperado 15 octubre, 2019, de http:// hdl.handle.net/10757/622178

6. Diario Gestión. (2019, 2 septiembre). Caen precios de departamentos de Mivivienda en últimos cuatro meses. Recuperado 10 septiembre, 2019, de https://gestion.pe/economia/caen-precios-de-departamentos-de-mivivienda-en-ultimoscuatro-meses-noticia/

7. Diario Gestión. (2019, 28 agosto). Villa Panamericana: Valor de departamentos sería muy caro para la zona. Recuperado 10 septiembre, 2019, de https://gestion.pe/economia/villa-panamericana-valor-de-departamentos-seria-muycaro-para-la-zona-noticia/

8. El Comercio. (2017, 4 septiembre). Lima 2019: consorcio Besco-Besalco gana ejecución de Villa Panamericana. Recuperado 20 septiembre, 2019, de https://elcomercio.pe/lima/sucesos/lima-2019-consorcio-besco-besalco-gana-ejecucionvilla-panamericana-noticia-455500

9. El Comercio. (2019, 20 agosto). Precio del metro cuadrado en Lima crecería hasta en $8 \%$ al cierre del 2019. Recuperado 4 septiembre, 2019, de https://elcomercio.pe/economia/peru/precio-metro-cuadrado-lima-creceria-8-cierre2019-noticia-nndc-666961

10. El Comercio (2019, 31 agosto). PBI: Crecer 1\% menos impide crear más de 48.000 empleos. Recuperado 4 septiembre, 2019, de 
https://elcomercio.pe/economia/peru/economia-peruana-pbi-crecer-1-impide-crear-48000-empleos-noticia-ecpm-670942

11. Empresa Peruana de Servicios Editoriales S. A. EDITORA PERÚ. (2019, 14 agosto). Boom inmobiliario en Lima Sur a la vista por venta de departamentos Lima 2019. Recuperado 4 septiembre, 2019, de https://andina.pe/agencia/noticia-boominmobiliario-lima-sur-a-vista-venta-departamentos-lima-2019-763288.aspx

12. Frutos Torres, B. d. (2018). Los medios publicitarios: Investigación, planificación y gestión. Madrid: Editorial Sintesis

13. INEI. (2019). Comportamiento de la Economía Peruana en el Segundo Trimestre de 2019.2 Recuperado de https://www.inei.gob.pe/media/MenuRecursivo/boletines/pbi_trimestral.pdf

14. Inmobiliaria Marketing . (s.f.). https://inmobiliariamarketing.com/. Revisodo Octubre 13, 2019, from https://inmobiliariamarketing.com/google-adwords-parainmobiliarias/

15. Inmobiliaria Marketing. (2017, 29 junio). ¿Cuánto cuesta una estrategia de marketing digital inmobiliario? Recuperado 15 octubre, 2019, de https://inmobiliariamarketing.com/coste-marketing-digital-inmobiliario/

16. Inmobiliaria Marketing. (2019, 3 julio). Las Claves del Marketing Digital Inmobiliario en 2019. Inmobiliaria Marketing.. Recuperado 15 octubre, 2019, de https://inmobiliariamarketing.com/claves-marketing-digital-inmobiliario/

17. Ipsos. (2019). Estadística poblacional 2019 (Edición Especial).

18. Ipsos. (2015). Hábitos y actitudes hacia los medios de comunicación alternativos 2015

19. Ipsos. (2017). Hábitos y actitudes hacia los medios tradicionales.

20. Ipsos. (2018). Perfil del Jefe del hogar peruano 2018.

21. Ipsos. (2019). Perfiles Socioeconómicos de Lima Metropolitana 2018. Recuperado de https://www.ipsos.com/es-pe/perfiles-socioeconomicos-de-lima

22. Ipsos. (2019). Perfiles zonales Lima Metropolitana 2019.

23. Logaster. (2018, 8 noviembre). Cómo Escoger una Fuente Para su Logotipo. Recuperado 17 septiembre, 2019, de https://www.logaster.com.es/blog/how-to-choosefont-for-logo/ 
24. MiVivienda. (s.f.). Fondo MIVIVIENDA - Mivivienda Verde. Recuperado 4 septiembre, 2019, de https://www.mivivienda.com.pe/portalweb/usuario-buscaviviendas/pagina. $\operatorname{asp} x$ ?idpage $=450$

25. MiVivienda. (s.f.). Fondo MIVIVIENDA - Nuevo Crédito Mivivienda. Recuperado 4 septiembre, 2019, de https://www.mivivienda.com.pe/portalweb/usuariobusca-viviendas/pagina.asp $x$ ?idpage $=20$

26. Rockcontent. (2019, 18 marzo). Mejores horarios de publicación para redes sociales 2018. Recuperado 17 septiembre, 2019, de https://rockcontent.com/es/blog/horarios-de-publicacion/

27. Roommates.pe. (2018, 9 noviembre). $\triangleright 5$ portales inmobiliarios gratuitos de Perú, para publicar un anuncio. Recuperado 14 septiembre, 2019, de https://www.roommates.pe/5-portales-inmobiliarios-gratuitos-de-peru/1874/

28. Semana Económica. (2019, 28 agosto). BCP: proyecciones de crecimiento del MEF para 2019 y 2020 "lucen optimistas". Recuperado 3 septiembre, 2019, de http://semanaeconomica.com/article/economia/macroeconomia/371168-bcpproyecciones-de-crecimiento-del-mef-para-2019-y-2020-lucen-oprimistas/

29. Social Bakers. (2015, 17 febrero). Native Facebook Videos Get More Reach Than Any Other Type of Post. Recuperado 17 septiembre, 2019, de https://www.socialbakers.com/blog/2367-native-facebook-videos-get-more-reach-thanany-other-type-of-post

30. Ochoa, J. A. (2019, 7 junio). Psicología del color: más allá de la publicidad, hacia el bienestar emocional. Recuperado 17 septiembre, 2019, de https://search.proquest.com/central/docview/2241306088?pq-origsite=summon

31. Taylor, D. (2017). Buyer personas can help you understand customer perceptions. Central Penn Business Journal, 33(33), 12. 


\section{ANEXOS}

\section{Entrevista a especialistas en Marketing del rubro inmobiliario}

1. ¿Cuáles son las principales oportunidades para el sector inmobiliario en Lima Sur?

2. ¿Cuáles son los factores más importantes para la decisión de compra de un inmueble en el sector C y D?

3. ¿Consideras que el nombre "Villa de Altetas" se debería mantener para la venta de estos departamentos?

4. ¿Cuáles consideras que son las fortalezas del proyecto Villa Panamericana para su venta?

5. ¿Cuáles consideras que son factores negativos para la venta de Villa Panamericana?

6. ¿En qué ferias próximas se podría participar para publicitar Villa Panamericana?

7. ¿Cuál consideras que es el perfil de los compradores de departamentos en los sectores C y D?

Formato de encuesta a pobladores del Sector C Y D de la zona Lima Sur

1. Edad

2. Sexo

a. Femenino

b. Masculino

3. Distrito de residencia

4. ¿Conoces acerca de los beneficios del Nuevo Fondo Mi Vivienda?
a. Sí
b. No

5. Si respondiste Sí, ¿En qué consiste el Nuevo Fondo Mi Vivienda? 
6. ¿Conoces acerca de los beneficios del Bono Verde que ofrece el Estado al comprar un inmueble?

7. Si respondiste Sí, ¿En qué consiste el Bono Verde?
a. Sí
b. No

8. Califica en la escala del 1 al 5 (siendo 1 menos importante y 5 más importante) lo que priorizas al momento de elegir una vivienda
a. Seguridad
b. Dimensión del inmueble: número de habitaciones y baños
c. Cercanía a centro de estudios y trabajo
d. Instalaciones con sistema de ahorro de energía y agua
e. Cercanía a paraderos y avenidas principales
f. Cercanía a centros comerciales y tiendas
g. Cercanía a parques y centros recreativos
h. Áreas comunes: jardín, áreas recreativas, juegos para niños

9. ¿Qué atleta peruano representa para ti mejor la imagen del peruano luchador?
a. Gladys Tejeda
b. Piccolo" Clemente
c. Alexandra Grande
d. Christian Pacheco
e. Diego Elías

10. ¿Con qué nombre relacionas el condominio que se construyó para hospedar a los atletas de los Juegos Panamericanos y Para panamericanos en Lima del año 2019 ?
a. Villa Panamericana
b. Villa de Atletas
c. Villa de Campeones
d. Villa Deportiva

11. ¿Qué isotipo se relaciona más con el condominio donde se hospedaron los atletas para los juegos Panamericanos y Para panamericanos?
a. Opción 1
b. Opción 2 


\section{Visita a feria Nexo Inmobiliario el día 12 de Setiembre}

Se realizó una visita a la feria Nexo Inmobiliario en el Jockey Club donde se pudo apreciar lo siguiente:

- Las inmobiliarias que cuentan con proyectos con el Bono Verde decoran sus stands con ese color y con plantas artificiales para reforzar la idea de ser ecoamigables.

- En los stands de ventas se resalta bastante las áreas comunes en los edificios familiares como juegos para niños o áreas de parrilla.

- Algunos stands dieron de cortesía bocaditos para las personas que se acerquen a pedir información, lo cual era una forma de atraer a más personas.

- Varias inmobiliarias ofrecían premios para los que separen su departamento como un scooter, muebles para la sala, cocina, entre otros.

- No encontramos inmobiliarias que tengan lentes de realidad virtual, por lo que es algo que puede llamar la atención en la participación de este tipo de ferias.

- A pesar de contar con el Bono Verde, ninguna inmobiliaria ofrecía información con flyers o brochures de papel reciclado.

- Había un stand de MiVivienda con bastante público interesado por información. 